\title{
Roman Pottery from an Intensive Survey of Antikythera, Greece
}

\author{
A. Quercia, A. Johnston, A. Bevan, J. Conolly and A. Tsaravopoulos \\ Postprint of a 2011 paper in the Annual of the British School at Athens 105: 1-81 (doi: \\ $10.1017 / \mathrm{S} 0068245400000368)$.

\begin{abstract}
Recent intensive survey over the entire extent of the small island of Antikythera has recovered an episodic sequence of human activity spanning some 7,000 years, including a Roman pottery assemblage that documents a range of important patterns with respect to land use, demography and on-island consumption. This paper addresses the typological and functional aspects of this assemblage in detail, and also discusses Roman-period Antikythera's range of off-island contacts and affiliations.
\end{abstract} \\ ABSTRACT
}




\section{INTRODUCTION ${ }^{1}$}

This paper considers Roman pottery that was collected as part of an intensive survey of the Greek island of Antikythera, with particular focus on what this assemblage tells us about patterns of human activity on the island and over wider Aegean networks during the 1 st to the 7 th centuries AD. Antikythera is one of the smaller (20.8 sq.km) and more remote inhabited islands in the Mediterranean, but is situated along some key shipping lanes, between the Peloponnese and Crete and between the Adriatic and Aegean seas. It has had a long but very episodic history of human exploitation over some 7,000 years, and has at times been punctuated by periods of near or total abandonment. Its pottery record is of great interest not only to specialists in the material culture of the region, but also to those interested in the challenging patterns of isolation and connection experienced by Mediterranean island communities, as well as the unusual material, ideological and subsistence strategies such challenges have sometimes promoted.

1 The first author should be used for all correspondence (aq15@le.ac.uk). The Antikythera Survey Project has been a collaboration between Bevan, Conolly and Tsaravopoulos and we would like to thank the Greek Ministry of Culture, the Greek Archaeological Service (26th EPKA, 1st EBA), as well as our three primary external funding agencies over the duration of the project-the Social Science and Humanities Research Council of Canada, the UK Arts and Humanities Research Council and the Institute for Aegean Prehistory. The Mediterranean Archaeological Trust also contributed to the costs of photographing and illustrating the artefacts included in this paper. Our sponsor in Athens has been the Canadian Institute in Greece and we are particularly grateful to Jonathan Tomlinson for his assistance. Several of us have also been involved in survey work on the neighbouring island of Kythera, with the Kythera Island Project (KIP) (www.ucl.ac.uk/kip), and we would like to thank Cyprian Broodbank and Evangelia Kiriatzi (KIP co-directors) for much advice and support. The corresponding author is also grateful to Brunella Bruno (Superintendence of Archaeology of Veneto, Italy) and Rita Auriemma (University of Salento, Italy) for specific suggestions with regard to the transport amphorae discussed here, as well as to Roberta Fabiani (University of Perugia, Italy and Humboldt University, Germany) for references to the linguistic issues concerning the lamp inscription (40) and Kathleen Slane (University of Missouri) for a range of useful advice. Denitsa Nenova illustrated the sherds catalogued here, with further assistance from Marek Maciusowicz and James O'Neill. The following special abbreviations are used throughout the text:

Atlante $I=$ Enciclopedia dell'arte antica classica e orientale. Atlante delle forme ceramiche. I. Ceramica fine romana nel bacino mediterraneo (medio e tardo impero) (Roma, 1981).

Atlante II = Enciclopedia dell'arte antica classica e orientale. Atlante delle forme ceramiche.

II. Ceramica fine romana nel bacino mediterraneo (tardo ellenismo e Primo Impero) (Roma, 1985)

Ostia II = Berti, F., Carandini, A. and Fabbricotti, E. Ostia II. Le terme del Nuotatore: scavo dell'ambiente I, (Studi Miscellanei, 16; Roma. 1970)

Ostia III = Carandini, A., Fabbricotti, E. and Palma, B. Ostia III. Le terme del Nuotatore: scavo degli ambienti III, IV, VII. Scavo dell'ambiente V e di un saggio nell'area Sud-Ovest, (Studi Miscellanei, 21; Roma, 1973).

The following list of abbreviations for pottery classifications are used throughout the text and tables:

ARS, ARSW: African Red Slip, African Red slip Ware

ARC (1, 2, 4): 'Antico Romano Cretese' amphora

ESA: Eastern Sigillata A

ESB: Eastern Sigillata B

ESC: Eastern Sigillata C

LRA (types 1, 2, 3, 5/6, 7): Late Roman Amphora

LRD: Late Roman D (=Cypriot Red Slip Ware)

MRC (types 1, 2, 3): 'Medio Romano Cretese' amphora

PRSW: Phocaean Red Slip Ware 
Perhaps the most best known archaeological discovery associated with Antikythera is a 1st century BC shipwreck off the north coast of the island that produced the socalled Antikythera mechanism (an intricately-geared astronomical device) and a range of other impressive bronze statues, ceramic and glass finds (most recently Freeth et al. 2006, with further references). This shipwreck, as well as a range of finds at the impressively fortified site known as the Kastro on the island itself, Hellenistic material of late 4th to mid 1st century BC date, reflect a period in which the documentary sources suggest that Antikythera, then referred to as Aegil(i)a, was heavily involved in piracy (Stais 1889; Petrocheilos 1987; Martis, Zoitopoulos and Tsaravopouls 2006; Tsaravopoulos 2004-7; Johnston et al. in prep.). In fact, the final destruction of this site is one plausibly linked to the anti-piracy of Creticus Metellus in 67-64 BC. Following this period, there may have been a break in settlement (that we discuss further below), but thereafter the island was clearly inhabited again by the Late Roman period, as recently documented by the excavation of several cist grave cemeteries (e.g. Pyrrou, Tsaravopoulos and Bojica 2006). ${ }^{2}$

In addition to these excavated finds, a complementary picture of human activity on Antikythera has recently been provided by a separate programme of intensive surface survey covering the whole island (the Antikythera Survey Project [ASP]). ASP has involved input from a broad range of specialists interested in the long-term human ecology of the island, in all periods of its history (e.g. Bevan, Conolly and Tsaravopoulos 2008; Bevan and Conolly 2009). The surface survey itself was one aspect of this research effort and its first stage (the only one of relevance here) was conducted in 2005-6 by five person teams walking across the island in lines $15 \mathrm{~m}$ apart. ASP counted over 65,000 potsherds in this manner and made a permanent collection of about 7,725 'feature' sherds for subsequent laboratory study (i.e. all rims, bases, handles and all those with paint, glaze or other decoration). Of these collected finds from first stage survey, nearly four thousand are most likely datable to somewhere within the first seven centuries $\mathrm{AD}$, and this paper offers a detailed assessment and selected catalogue of them, to go alongside (i) a less discursive, but comprehensive online publication of ASP datasets in digital form and (ii) a short synthesis of the survey results to be published elsewhere.

\section{$<<$ Insert Figure 1 here $>>$}

The Roman pottery collected during the intensive survey of Antikythera offers a spatially-controlled, landscape-scale view of the on- and off-island strategies pursued by its inhabitants and others who passed by, deliberately or by accident. However, as is often the case with survey material, the correct identification of different diagnostic shapes is sometimes hampered by the poor preservation of surface treatments such as slips and decoration. A total of 3886 sherds were collected that can definitively or at least possibly be dated to the Roman period (50.3\% of the diagnostic sample), but of these only about $45 \%$ can be associated with well-known and attested ceramic types and hence be attributed to a sub-phase within this period (what we will hereafter call the 'finely-diagnostic' material). Related to this problem is the fact that, the vast

\footnotetext{
2 Stephen of Byzantium's Ethnica (ca 530 AD) also comments on the island to the effect that "an inhabitant is called Aigilios, just as [an inhabitant of Kythera is called] Kytherios". One uncertain early find of Roman date from the island is a large medal of Antoninus Pius said to be from 'Cerigotto' (Smyth 1834, 118, no.200).
} 
majority of the Roman assemblage comprises body sherds (32\%) and handles (43\%, often heavily-abraded), while rims and bases are fewer in number $(18 \%$ and $7 \%$ respectively). This large proportion of only loosely identified and dated Roman material therefore necessitates caution in our interpretation of the overall assemblage, but two general patterns stand out very clearly:

Some $80 \%$ of the finely-diagnostic material can be dated to the Late Roman period (from late fourth/fifth to seventh century AD), while pottery unequivocally datable to the Early (in ASP terms, from first to second century AD) and Middle Roman period (from third to fourth century AD) is far (?) attested. Almost $60 \%$ of the artefacts analysed are transport amphorae (mainly fragments of bodies and handles, with the more finely diagnostic rims and toes far less well attested). Coarse wares are far less common (ca 31\%) and many of these are body sherds whose attribution to the Roman period remains uncertain. The amount of fine pottery is even more limited (ca 5\%).

As discussed further below, this survey assemblage requires careful interpretation. As David Pettegrew has stressed recently (2007), the quantities of Roman ceramics recovered by intensive surface surveys must be re-calibrated to compensate for the problems caused by differential diagnostic visibility. In particular, the frequently attested increase of Late Roman rural settlements and archaeological evidences in mainland and insular Greece in comparison with the fewer data relevant to the Early Roman period may partly reflect differences in visibility of the ceramic finds. In particular, a greater number of type fossils belonging to the Late Roman period (African Red Slip and Phocaean ware plates and bowls, grooved and ridged body sherds from amphorae) are significantly more visible and easily recognizable by surface treatment. By using a proper calibration of the ceramic data relevant to the East Corinthia survey, which were compared with others from different archaeological surveys in Greece, Pettegrew was able to demonstrate a more continuous pattern of habitation, trade and economic exploitation of the Greek landscape during the Roman Age and more subtle increase of archaeological evidence in the Late Roman period than may otherwise be indicated in the raw data. A similar trend is also present to some degree on Antikythera, where grooved body sherds from amphorae comprise a significant proportion of the Late Roman evidence.

The discussion below is divided into two chronological sections and further categorised by consistent functional categories (e.g. fine tablewares, amphorae, coarse cooking wares, etc.). The accompanying catalogue of over a hundred drawn sherds provided here is only a small selection of the overall finds, but offers examples of the main forms on the island, as well as a point of departure for considering various offisland parallels. The catalogue uses a single running number sequence throughout, but readers should also take note of the associated field identifiers (in brackets) as these are the ones physically marked on the finds and to be used in other ASP publications.

\section{EARLY AND MIDDLE ROMAN POTTERY (1ST TO EARLIER 4TH CENTURY AD)}

The Early and Middle Roman period represents approximately $18 \%$ of the overall Roman assemblage. On the whole, the presence of Italian and African imports as well 
as Aegean and Cretan amphorae in the Late Hellenistic Age/Early Roman period, and later, leads us to suggest a rather lively exchange which involved the island and is reminiscent of other well known assemblages, such as those at Ephesus, where a recent analysis of the transport vessels suggests the occurrence of western supplies from the end of the 2nd century BC (Bezeczky 2006).

\subsection{FINE WARES (FIG.2)}

The amount of fine ware is very limited, consisting mainly of body sherds and bases, while rims are few. There is limited evidence for vessels of eastern production (9\% of the overall pottery of this phase), of which the best attested is Eastern Sigillata C (ESC) that was probably produced at Pergamum from the 2nd century BC until the late 2nd or early 3rd century AD (1). The other well-known eastern fabrics (e.g. ESA, ESB) are not securely attested within the survey assemblage, despite the fact that ESA plates and cups were found on the Antikythera shipwreck (Robinson 1965, dated to the middle of the 1st century $\mathrm{BC}$ ), but there are nonetheless some imitations of one form, ESB 60 (3), whose place of production is unknown. Other Early and Middle Roman fine wares such as Italian Sigillata and African Red Slip (fabrics A and A/D) have not been identified.

\subsection{AMPHORAE (FIGS.6-7)}

In contrast to the paucity of fine tablewares of Early to Middle Roman date, the evidence for transport amphorae is more substantial. Amongst this material, Aegean products seem to be better represented than Italian and African amphorae (the former comprising around $60 \%$ of the overall Early and Middle Roman amphorae assemblage). In particular, Cretan amphorae (58-63), typically associated with the transportation of local wine, are fairly common on Antikythera (29\%), with ARC 1 and 2 well attested and ARC 4 less frequent (for the types, see Marangou-Lerat 1995; Portale and Romeo 2000; 2001). Some sherds may also be from later Cretan amphora fabrics (64-65, types MRC 1/3 and MRC 2, see Portale and Romano 2000; also Hayes 1983, 141-143) and are thus possible, but uncertain, evidence that such amphorae may have been arriving on the island up until the Late Roman period. It is worth noting that Cretan amphorae were also found in significant quantities at Argos, from the first half of the $1^{\text {st }}$ century BC (27-38\% of all amphorae; Abadye-Reynal 2007, 264).

As far as the other Aegean amphorae are concerned, the poor preservation of the sherds does not always allow firm identifications, especially for a series of rolled or rounded rims (that could be Rhodian, Knidian or Koan amphorae). Some fragments may be consistent with Late Rhodian wine amphorae, which developed from Hellenistic prototypes (51-53) and would date sometime within the period from the late 1st century $\mathrm{BC}$ to the mid $2 \mathrm{nd}$ century AD. Archaeometricanalysis suggests several different production centres for these types, all probably located within the parts of the Aegean and western Anatolia that were under the economic and political control of Rhodes (such as the Rhodian Peraia and the Knidian peninsula; Empereur and Picon 1989; Empereur and Tuna 1989; Whitbread 1995, 53-67). Certain amphora rims amongst the survey material whose clay has distinctive red grains recall Rhodian fabric 1 (Peacock 1977; Peacock and Williams 1986, 103) and these suspicions of group V or VI Rhodian amphorae on the island are further strengthened by the presence of similar items in the cargo of the Antikythera shipwreck (Grace 1965, 14, fig. 2). 


\begin{tabular}{|c|c|c|c|c|c|c|}
\hline Production & Types & Rims & Bases & Handles & Bodies & Total \\
\hline \multirow{6}{*}{$\begin{array}{l}\text { Italian } \\
(16 \%)\end{array}$} & $\begin{array}{l}\text { Late } \\
\text { Republican } \\
\text { Italic } \\
\text { amphora }\end{array}$ & & 2 & 2 & & 4 \\
\hline & $\begin{array}{l}\text { Late } \\
\text { Republican } \\
\text { Italic } \\
\text { amphora } \\
\text { (Tyrrennian } \\
\text { fabric) }\end{array}$ & & & 3 & 2 & 5 \\
\hline & Dressel 1 & & & 1 & & 1 \\
\hline & \begin{tabular}{|l} 
Dressel 1B- \\
C/Pascual 1
\end{tabular} & 5 & & & & 5 \\
\hline & Lamboglia 2 & 1 & 1 & & & 2 \\
\hline & Dressel 6 & & 1 & 3 & & 4 \\
\hline $\begin{array}{l}\text { Iberian } \\
(1 \%)\end{array}$ & Dressel 20? & & 1 & & & 1 \\
\hline \multirow{8}{*}{$\begin{array}{l}\text { African } \\
(25 \%)\end{array}$} & Maña C1a & 3 & & & & 3 \\
\hline & Maña C2a & 4 & & 3 & 4 & 11 \\
\hline & \begin{tabular}{|l} 
Punic \\
amphora
\end{tabular} & 7 & & 3 & 3 & 13 \\
\hline & $\begin{array}{l}\text { Early } \\
\text { Tripolitanian }\end{array}$ & 1 & & & & 1 \\
\hline & $\begin{array}{l}\text { Tripolitanian } \\
2\end{array}$ & 1 & & & & 1 \\
\hline & Africano 1 & & 1 & & & 1 \\
\hline & Africano $2 \mathrm{~A}$ & 1 & & & & 1 \\
\hline & Africano 2 & 1 & 1 & & & 2 \\
\hline \multirow{8}{*}{$\begin{array}{l}\text { Aegean } \\
(29 \%)\end{array}$} & $\begin{array}{l}\begin{array}{l}\text { Dressel 2-4 } \\
\text { (not } \\
\text { Tyrrhenian } \\
\text { fabric) }\end{array} \\
\end{array}$ & 2 & & 6 & & 8 \\
\hline & $\begin{array}{l}\text { Rhodian } \\
\text { amphora }\end{array}$ & 7 & 1 & 4 & & 12 \\
\hline & \begin{tabular}{|l} 
Rhodian \\
amphora?
\end{tabular} & 4 & 1 & & & 5 \\
\hline & \begin{tabular}{|l|} 
Rhodian \\
type/Dressel \\
$2-4$
\end{tabular} & 1 & & & & 1 \\
\hline & \begin{tabular}{|l|} 
Mau \\
XXXVIII
\end{tabular} & & 1 & & & 1 \\
\hline & Kapitän2 (?) & & & 7 & & 7 \\
\hline & $\begin{array}{l}\text { Kapitän1-2 } \\
\text { (?) }\end{array}$ & & & 1 & & 1 \\
\hline & Agora 199? & & 2 & & & 2 \\
\hline Cretan & ARC 1 & 9 & & 3 & & 12 \\
\hline
\end{tabular}




\begin{tabular}{|l|l|l|l|l|l|l|}
\hline (29\%) & ARC2 & 1 & & & & 1 \\
\hline & ARC1-2 & 8 & 1 & & 1 & 10 \\
\hline & ARC4 & 6 & & & & 6 \\
\hline & ARC 2/4 & 2 & & & & 2 \\
\hline & MRC2? & 1 & & & & 1 \\
\hline & MRC1/3 & 1 & & & & 1 \\
\hline \multirow{5}{*}{ Total } & & 66 & 13 & 36 & 10 & 125 \\
\hline
\end{tabular}

Table 1. Attested types of Early and Middle Roman amphora

In addition, Dressel 2-4 amphorae are clearly attested on Antikythera by their distinctive bifid handles (e.g. 56): the fabrics of these might be Aegean but not Italian, as none have the black volcanic inclusions typical of Latial and Campanian Dressel 24 production. The few preserved rims of Dressel 2-4 may be consistent with a later type derived from the Koan amphora (55) that was very common in the Mediterranean area from the 1 st century BC into the 2nd century AD and exhibits a chronological evolution of the form (Grace 1979). Koan type amphorae have been also found in the cargo of the Antikythera shipwreck(Grace 1965, 15-16, figs. 1 and 4). A few handles may conceivably be of Kapitän II/ Niederbieber 77 type (58; see Bruno 2005, 288), but the attribution remains far from certain. The place of production for this wine amphora type is not known (but perhaps Ephesus?), but but from the end of the 2 nd to the 4 th and 5 th centuries $\mathrm{AD}$, it enjoyed a wide distribution across the Mediterranean from the Aegean to Gaul (for the Aegean, see AbadieReynal 1989, 145; for Corinth, see also Slane 2000, 301-302). Other amphorae of Aegean manufacture are very scarce: a ring foot may conceivably be from the Mau XXXVIII type (57), a wine amphora that was produced at Knidos and on or near the Datcha peninsula.

Late Republican and Early Roman Imperial (1st century BC to 1st century AD) amphorae produced along the Italian Adriatic coast are attested by a few fragments of Lamboglia 2 and Dressel 6 (41-43), while some long oval-shaped handles and body sherds with a fabric rich in black volcanic inclusions is typical of the coastal area of Italy from Etruria to Campania. These are probably of the Dressel 1 type, one of the most common Late Republican Roman amphorae that circulated from the latter half of the 2 nd century BC to sometime during the 1 st century BC. The identification of some high collar rims is problematic (40) since the shape is similar to a variant Dressel 1B, but the fabric does not seem to be Tyrrhenian and it is closer to that of a Pascual 1 amphora that was produced along the Catalan coast of north-eastern Spain (from the middle of the 1st century $\mathrm{BC}$ to the end of the 1st century $\mathrm{AD}$ ). Traditionally, the Lamboglia and Dressel 6 amphorae are thought to have been wine containers (Bruno 2005), but the question of contents and provenance is more complex than first thought. Will $(1997,123-125)$ minimizes the extent of Italic wine trade in the Aegean and assumes instead that these two amphora types mainly contained olive oil. On this interpretation, olive oil would have been the most popular comestible commodity imported in shipping amphorae to Athens and Delos from the during the late second and early first centuries BC. In contrast, but following the same logic, Aegean wines (mainly Rhodian and Knidian) would thus have been more popular than Italian wines, with the latter only starting to be imported to Athens in significant quantities from the latter half of the $1^{\text {st }}$ century BC. Recently Lindhagen (2009) has considered both Lamboglia and Dressel 6 to be wine amphorae arriving 
from the Dalmatian coast.

Overall the Late Hellenistic/Early Roman period imports from Italy to the island are limited in number but also occur on the Antikythera shipwreck (Grace 1965, 11). This limited presence of Italian wine amphorae is similar to the pattern observed at Gortyn on Crete, where analysis demonstrated that imports of Italian wine were very limited, while local products comprised over $80 \%$ of the amphora assemblage (Portale 2004). However, when considered at the wider Aegean scale, these proportions are modest and run counter to the overall pattern of an increasing number of Italian wine amphorae in the Aegean after the fall of Corinth and Carthage (e.g. on Delos: Lund 2000, 86ff). In contrast, to these amphorae of probable late Hellenistic/early Roman date, no Middle Roman Italian amphorae have been identified on Antikythera.

Late Punic and Roman Imperial African amphorae are clearly present in the survey assemblage (25\% of the Early and Middle Roman amphorae). In particular, amphorae from a Punic tradition (Mana C1a and $\mathrm{C} 2 \mathrm{a} ; \mathbf{4 5 - 4 6}$ ) are clearly present. The production centres of these amphorae, whose content was probably fish sauce, were located in North Africa (Tunisia, Morocco, Tripolitania) and were certainly operating at the end of the 3rd and the early part of the 2 nd century BC, but recently excavated contexts at Carthage also suggest that the date of Mana C2a/Van der Werff 1 vessels can be extended into the first half of the 1st century AD (Martin-Kilcher 1999). Early Tripolitanian amphorae which represent a typological link between Late Punic transport vessels and standardized Tripolitanian amphorae (mid 2nd century BC to the end of the 1st century BC or early 1st century AD) are also attested by at least one rim (47). Some commentators (Wolff 2004; Lawall 2006) have recently suggested that the modest numbers of Late Punic amphorae in the Aegean and eastern Mediterranean may have been the result of Roman economic protectionism that sought to circumscribe eastwards trade. However, they also note that there are possible recovery biases present here and the actual quantities of such amphorae may have been underestimated by comparison to Italian imports (due to a lesser degree of specialist awareness of possible Punic examples in this region). The African amphorae belonging to the Early and Middle Roman phases are far less common on Antikythera: a rim of Tripolitanian 2 type (48) and a few examples of Africana 2A (49-50) suggest the limited presence of these popular North African products on the island from the end of the 1st century AD to sometime in the 4th century AD (with the Tripolitanian vessels perhaps containing fish sauce and the Africana 2A possibly wine: Bonifay 2004). The Antikythera data follow the general trend that suggests only a limited presence of African amphorae (which supplied Italian and western markets with oil and cereals) in the Aegean up to at least the $4^{\text {th }}$ century AD, in contrast to African Red Slip vessels that were very popular in the eastern Mediterranean. This paucity of African amphorae can probably be explained as the result of local Aegean production of these foodstuffs during this period (Abadie-Reynal 1989, 145-148).

Iberian imports are almost entirely absent from the Antikythera survey assemblage, apart from one possible base of a Dressel 20 type (44), despite the fact that these were the most common olive oil amphorae in the entire Mediterranean during the Roman Imperial period (from the 1st to the 3rd century $\mathrm{AD}$; for their occurrence in the Aegean, see Bernal Casasola 2000, 940-942). 


\subsection{COARSE WARES (FIG.12)}

There are almost no securely-identifiable coarse wares or cooking vessels from the island that date to the Early and Middle Roman phases. One exception however is a fragment from a casserole with an oblique rim and internal cavity for the lid (94) that might belong to a common type produced in the Aegean area during the Middle Roman period (Hayes 1983). It is notable that there are no clearly identifiable African cooking pots of this date in the Antikythera assemblage, except for perhaps one body sherd. Nevertheless, it remains possible that very limited numbers of identified vessels of this functional type are partly an accident of recovery, given the large size of the Roman coarse ware assemblage that is morphologically undifferentiable by sub-phase.

\section{LATE ROMAN POTTERY (LATER 4TH TO 7TH CENTURY} AD)

Late Roman pottery is present in far greater recorded quantities ( $n=1486$ sherds) on the island than the pottery of the previous phases.

\subsection{FINE WARES (FIGS.3-5)}

The fine tablewares represent $11 \%$ of the overall pottery from this phase and perhaps more (25\%) if we exclude body sherds from the calculation (see below). There is very clear evidence (FIG. 8) of the prevalence of Phocaean Red Slip Ware (or Late Roman C), which exceeded half of the overall amount (58\%); the African Red Slip is far less well-attested (19\%). Phocaean RS Ware (PRSW) was produced in Phocea and Gryneion from the end of 4th to the mid 7th century AD and contemporary local productions that imitated the Phocaean wares have been identified at several sites in Asia Minor, including Ephesus, Sardis, Pergamon, Chios, Priene and Anemurium (see Gassner 1997; Schneider 2000, 533, Ladstätter 2005). A local imitation made on Crete has also been suggested, but without archaeometrical confirmation (Vogt, Gouin and Aloupi 2000, 56-57; Vogt 2004, 925-928). PRSW was very common in the Aegean and the eastern Mediterranean from the end of 5th century AD (Hayes 1972, 417-419 and 423-424) and it significantly outnumbers African Red Slip wares in most assemblages with only a few exceptions (e.g. Cyprus, around Alexandria, and in some parts of southern Asia Minor), reaching ca80-85\% of the fine ware assemblages on Crete (e.g. Gortyn, Eleutherna) and at Argos (Abadie-Reynal 2007, 150ff; also dominant at Corinth: Slane 2000, 303).

On the basis of new evidence and new publications, Hayes $(2008,83-88)$ proposed recently a revision of some aspects of the PRSW, in particular regarding its early phases and the period after ca 540-550 AD. Some Athenian contexts show the Phocaean ware in competition with the African products already since the early 5th century AD: in the late 5th century Agora groups the Phocaean ware topped 80-90 \% of the imported fine wares. Moreover, recent evidence from other sites such as San Giacomo degli Schiavoni (Italy), Iatrus (Bulgaria) and Beirut have to be considered for the redating of PRSW (Hayes 2008, 85-86: see also Slane and Sanders 2005, 283 and 289).

\begin{tabular}{|l|l|l|l|l|l|l|l|}
\hline Production & Types & Rims & Bases & Handles & Bodies & Total & $\%$ \\
\hline ARSW (19\%) & ARSW/ PRSW & & 1 & & & 1 & 0.6 \\
\hline
\end{tabular}




\begin{tabular}{|l|l|l|l|l|l|l|l|}
\hline & ARSW & 1 & 6 & & 1 & 8 & 4.2 \\
\hline & Hayes 50 & 2 & & & & 2 & 1.5 \\
\hline & Hayes 67 & 4 & & & & 4 & 2.4 \\
\hline & Hayes 67/69 & 1 & & & & 1 & 0.6 \\
\hline & Hayes 82A & 1 & & & & 1 & 0.6 \\
\hline & Hayes 87A & 1 & & & & 1 & 0.6 \\
\hline & Hayes 99 & 2 & & & & 2 & 1.2 \\
\cline { 2 - 8 } & Hayes 104/105 & & 3 & & & 3 & 1.8 \\
\cline { 2 - 8 } & Hayes 104 & 6 & & & & 6 & 3.6 \\
\cline { 2 - 8 } & Hayes 105 & 1 & & & & 1 & 0.6 \\
\hline \multirow{5}{*}{ PRSW (58\%) } & PRSW & 7 & 19 & & 3 & 29 & 15.8 \\
\cline { 2 - 8 } & PRSW form 1 & 4 & & & & 4 & 2.4 \\
\cline { 2 - 8 } & PRSW form 2 & 4 & & & & 4 & 2.4 \\
\cline { 2 - 8 } & PRSW form 3 & 32 & 2 & & & 34 & 20.6 \\
\cline { 2 - 8 } & PRSW form 10 & 22 & & & & 22 & 13.3 \\
\hline Unknown (23\%) & Late Roman RS & 26 & 7 & 1 & 3 & 37 & 20.6 \\
\hline Total & & 121 & 42 & 2 & 8 & 173 & 100 \\
\hline
\end{tabular}

Table 2. Attested types of Late Roman fine ware

However, the PRS vessels found on Antikythera comprise only a limited number of shapes and types. The frequency of earlier types (forms 1 and 2; 12-14, 16 and perhaps 15), which date throughout the end of the 4th and the first half of the 5th century $\mathrm{AD}$, is fairly smalland the main attested types are forms 3 and 10 . The type 3 bowl (17-22) was the most widespread PRS form in the Mediterranean area, especially between the second half of 5th and the beginning of the second half of 6th century AD and includes numerous variants of 5th century (B and C) and 6th century (E) date, often with rouletting decoration (e.g. 23) and in one case a stamped "Star of David" motif (27). Form 10 (23-25) dates from the late 6th century to mid 7th century $\mathrm{AD}$ and is supposed to be the last type produced in PRSW.

African Red Slip (ARS) wares were produced in northern Tunisia and are commonly attested in the Mediterranean during the Late Roman period. Their numbers are not as large in the Aegean and the eastern Mediterranean as they are in the western Mediterranean, not least due to the popularity of PRSW in the east. In this respect, however, the south-western Aegean (from Crete to Boeotia) is an intermediate zone that was generally more receptive to African fine wares than the rest of the eastern Mediterranean (Sodini 2000, 194; Abadie-Reynal 2007, 153-156). Starting from the $3^{\text {rd }}$ century AD, some ARS wares consistent with production C (such as types H45 and 50A) are massively attested in the south Aegean and exceed ESC production, for example, at Argos (Abadie-Reynal 1989, 144; 2007, 171), Athens (Hayes 2008, 7173) and Corinth (Slane 2000, 303 and 307: Slane 2003, 330). This pattern is probably related to the foundation of Constantinople and the resulting increase of long distance trade from west to east, in which centres such as Corinth played an important role as transhipment points (Slane 2003, 331; see also Slane 2000, 307 and 310-311). According to some commentators, the production of such fine wares ran alongside the increasing supplies of grain from North Africa to the East, which started even before the foundation of Constantinople (Abadie-Reynal 2007, 173-174). 
The number of African fine wares gradually decreases during the 5th century AD (Abadie-Reynal 2007, 150ff), at the same time as there is a sharp increase in Phocaean Red Slip wares (PRSW), and these remain scarce in the Aegean until the second half of the 6th century or early part of the $7^{\text {th }}$ century AD, after which their quantities increased considerably at the same time as typical amounts of PRSW decrease slightly (Vogt 2004, 928-930). It might be assumed that strategically and economically important centres and exchange market points were mainly involved in this significant increase of African fine wares, such as Athens (Hayes 2008, 73), Corinth (Slane 2000, 306), Antioch, Constantinople and Argos (Abadie-Reynal 2007, 153-156). It is also noteworthy that the African sigillata was associated with long distance trade routes and the main urban centres, while the presence of Phocaean RS ware was also associated with secondary markets (Abadie-Reynal 2007, 153-156).

In contrast to this general pattern, the prevalence of ARS wares on Antikythera seems slightly different. Just one rim belongs to the latest production of ARS fabric C (4) that can be dated to the 5th century AD. The rest of the ARS fragments on Antikythera belong to the later phases of ARS fabric D and are attested by a limited number of types (5-8) that, more broadly, are some of the most common ARS vessel shapes in the Mediterranean during the 5th and 6th centuries AD. On Antikythera, plates of Hayes form 67 (e.g. 6) that belong to the earlier phases of fabric D production (our variant is dated in the first half of 5th century AD) are slightly more frequent than the other types. Plates of Hayes form 104 and 105 (9-10) that were circulating in the Mediterranean area during the second half of the 6th to the mid 7 th century $\mathrm{AD}$, are the best represented and it is possible that further unattributed base fragments also belong to these type forms. In contrast, it is also interesting that the final products of ARS ware (i.e. the Hayes forms 108, 109, 99C) that were frequent throughout the 7th century AD seem to be missing from Antikythera.

Among the fine pottery there is also a significant number of red slipped sherds (over $20 \%$ of the fine ware assemblage) that exhibit some consistency in shape, surface treatment and fabric, but that cannot at the moment be attributed to a known production group. They are dishes and bowls, characterized by a very fine fabric (pinkish or light brown in colour), with a very thin slip (sometimes quite diluted and uneven). Most of these vessels are similar to ARS Hayes forms 104 and 105, PRS form 10 and Cypriot Red Slip Ware forms 9 and 10 (28-29, 31-32, 34-35, 37) and hence match well the main ARS and PRS types found on the island. They also recall plates and bowls discovered in a 7th century AD context at Knossos and interpreted as a "local / regional RS ware" that was imitating ARS shapes (Hayes 2001, 445, fig. 6, 8-15). On the base of comparanda with ARS and PRS wares, this group may well be a discrete Late Roman production whose place of origin is still unknown.

These fine ware dishes and bowls make an interesting group and deserve to be studied more thoroughly and across a wider range of assemblages in order to identify one or more possible centres of production, to establish both their chronological range and spatial distribution, and to clarify the full suite of forms that they imitate. In the Late Roman period, local imitations of ARS and PRS wares were very frequent in the Mediterranean basin and are evidence both for links between different production centres and for the impact of consumer preferences. Local RS fabrics have been identified or at least suspected, for several sites on Crete, including Gortyn, Eleutherna and Knossos (Hayes 2001), at Argos on the mainland, and at many other 
sites in the Aegean and eastern Mediterranean, such as Demetrias, Ephesus and Sardis (Yangaki 2005, 120, 291-292). The local production at Gortyn ("ceramica ad engobbio rosso") had a wide chronological range from the 2nd to the 6th century AD and imitated prototypes consistent with ESB, ARS and PRS wares (with earlier production more heterogeneous, and Late Roman production more systematic and homogeneous: Dello Preite and Martin 1997; Lippolis 2001). Vogt (2004, 925-928) identified a production of pseudo-PRS ware at Eleutherna that he supposed to be local and that imitated exactly a series of Phocaean forms but over a longer chronological range (Yangaki 2005, 291). These products were more common that ARS sherds at Eleutherna, but scarce in comparison with PRS wares. The description of local RS wares discovered at Argos (Aupert 1980, 418) suggests that they are very similar to the Antikytheran examples, with imitations of ARS Hayes forms 104 and 105, pink or generally pale fabrics and dull, non-uniform red slip.

At present it is very difficult to identify the place of origin of the RS wares found in Antikythera and to understand their economic and cultural impact. Moreover, the general overview of the local/regional fine wares is not yet well defined and known and does not permit a full knowledge of this issue, mainly as far as the links and the ratios to the most common imports are concerned. It might be supposed that the RS pottery from Antikythera could be consistent with a phenomenon which was common in the Mediterranean from the 5th to 7th centuries AD: a series of local fine ware industries which referred to common morphological patterns derived from the ARS and PRS forms ${ }^{3}$ and supplied not only the production sites but also regional and interregional markets (Yangaki 2005, 292-293). They were probably ateliers which carried out standardized productions and a limited number of shapes and types imitating the imports attested in the sites where these workshops were identified; these productions were probably less expensive and supplied regional demands and purchasers who could not afford African and Phocaean imports and preferred local imitations and derivations (Yangaki 2005). Fontana (1998, 95, fig. 8) noticed the sizes of the Italian imitations of ARS vessels were smaller than those of original wares and suggested that this was an intentional choice on the part of local ateliers to meet purchasers' requirements in integrating their vessels into small sets of shapes and different food practices.

Finally, an imported lamp is also attested among the fine wares (39). It is of a type that was very common throughout the 5th-6th centuries AD in the Palestinian area, where it was produced, but which does not seem to have occurred very frequently in the Aegean. A Greek inscription in relief on the shoulder quotes a common religious formula ("The light of Christ shines for all") and some commentators (e.g. Leclercq 1928, 1108-1110) have suggested that these lamps played an important role in Palestinian Christian liturgy. In particular, it has been argued that they were part of a religious service associated with the "sacred fire" that was the only ceremony authorized by the Greek church in the 5th-6th centuries AD. The presence of these lamps outside Palestine is thus especially interesting and, as previously noted (Leclercq 1928), may conceivably have been part of the personal possessions of pilgrims who had once taken part in the ceremony.

3 Some commentators suggest the partial derivation of the PRSW types from those produced in ARSW (Sodini 2000, 182; Bonifay 2004, 459-460). 


\subsection{AMPHORAE (FIGS. 9-10)}

Transport amphorae are by far the best-attested ceramic class of the Late Roman assemblage. The distinctive groove decoration present on many of these vessels ensures that they are a highly recognizable class of artefact in field survey but consequently also risks biasing our assessment of other types and periods. All of the calculations below therefore seek to quote numerical ranges that both include and exclude body sherds in their calculations. In any event, transport amphorae comprise somewhere between 42 and $59 \%$ of the Late Roman assemblage (excluding or including body sherds). Those amphorae that can be more closely identified belong to a limited number of types and document the heavy dominance of Aegean and eastern vessels (and probably their contents) over African and Italian ones.

\begin{tabular}{|c|c|c|c|c|c|c|c|c|}
\hline Production & Type & Rims & Bases & Handles & Bodies & Total & $\begin{array}{l}\% \\
\text { (all) }\end{array}$ & $\begin{array}{l}\% \\
(\mathrm{RBaH})\end{array}$ \\
\hline \multirow{6}{*}{$\begin{array}{l}\text { African } \\
(1.4 \%)\end{array}$} & Keay 34 & 3 & & & & 3 & 0.2 & 0.7 \\
\hline & Keay 35 & 1 & & & & 1 & 0.1 & 0.2 \\
\hline & $\begin{array}{ll}\text { Keay } & 55 \\
?\end{array}$ & & & & 1 & 1 & 0.1 & \\
\hline & Keay 61 & 4 & & & & 4 & 0.3 & 0.9 \\
\hline & Keay 62 & 4 & 3 & & & 7 & 0.4 & 1.6 \\
\hline & \begin{tabular}{|l|} 
Keay \\
$61 / 62$ \\
\end{tabular} & & 1 & 1 & & 2 & 0.2 & 0.5 \\
\hline $\begin{array}{l}\text { Unknown } \\
(0.1 \%)\end{array}$ & $\begin{array}{l}\text { Flat base } \\
\text { amphora } \\
\text { (Castrum } \\
\text { Perti } \\
\text { amphora } \\
\text { ?) }\end{array}$ & & 1 & & & 1 & 0.1 & 0.2 \\
\hline \multirow{13}{*}{$\begin{array}{l}\text { Aegean and } \\
\text { eastern } \\
\text { Mediterranean } \\
(98.5 \%)\end{array}$} & $\begin{array}{l}\text { LR } \\
\text { amphora }\end{array}$ & 9 & 1 & 246 & 282 & 538 & 42.2 & 59.8 \\
\hline & LRA 1 & 8 & & 12 & 15 & 35 & 2.8 & 4.7 \\
\hline & LRA 1? & 3 & & 23 & 14 & 40 & 3.1 & 6.1 \\
\hline & LRA 2 & 53 & 1 & 11 & 328 & 393 & 30.8 & 15.2 \\
\hline & LRA 2? & 13 & & 19 & 187 & 219 & 17.1 & 7.5 \\
\hline & LRA 3 & & & & 2 & 2 & 0.2 & \\
\hline & LRA 3? & & 1 & & 2 & 3 & 0.2 & 0.2 \\
\hline & LRA 4? & 1 & & & 4 & 5 & 0.4 & 0.2 \\
\hline & LRA 5/6 & 1 & & 1 & 6 & 8 & 0.6 & 0.5 \\
\hline & \begin{tabular}{|l|} 
LRA \\
$5 / 6 ?$
\end{tabular} & & & & 5 & 5 & 0.4 & \\
\hline & LRA 7? & & 1 & 5 & 3 & 9 & 0.7 & 1.4 \\
\hline & \begin{tabular}{|l|} 
Samos \\
Cistern \\
Type \\
\end{tabular} & & & & 1 & 1 & 0.1 & \\
\hline & $\begin{array}{l}\text { Globular } \\
\text { small } \\
\text { amphora }\end{array}$ & 1 & & & & 1 & 0.1 & 0.2 \\
\hline Total & & 101 & 9 & 318 & 850 & 1278 & 100 & 100 \\
\hline
\end{tabular}


Table 3. Attested types of Late Roman amphora.

The best-represented type (74-75), attested by many distinctive grooved body sherds and a more limited number of rims, is the Late Roman Amphora 2 (22-48\%, excluding or including body sherds). It is one of the most common amphorae in the Late Roman Aegean and eastern Mediterranean (Pieri 2005, 85-93; see also for the Aegean occurrences: Karagiorgou 2001, 139-145). The container has a capacity of ca 40-45 litres and is globular with a short conical neck, an indistinct rim andtwo short handles from the shoulder to the neck, while the body is grooved with deep horizontal and later (late 6th century AD) wavy rilling. The type was produced from the early 4th century $\mathrm{AD}$ up to the first half of the 7th century $\mathrm{AD}$, with a sequence of changes in overall form visible over the course of the period. Centres of production have been identified near or along the western Anatolian coast (probably on Chios and at Cnidos) as well as in the Argolid (Kounoupi), but other places of origin are also possible. There is evidence that it was used to transport both wine and olive oil (as suggested by the Yassi Ada cargo for example: Karagiorgou 2001, 146), but with greater overall evidence for wine as a typical content (Pieri 2005, 92-93).

In contrast, Late Roman Amphora 1 (73) seems to be far less frequent than LRA 2 in the Antikythera assemblage (6 to $10 \%$ including or excluding body sherds). This amphora (for which, see Pieri 2005, 69-84) is characterized by a tall, narrow neck with a band rim and a small pear shaped body. Itsdistinctive handles are wrapped to create a deep concave groove or twisted, while the body has ridges that divide wide, stepped flat sections (the latter decoration occurring mainly in the 6th century AD). LRA 1 was produced along the southern coast of Turkey (Cilicia), on Rhodes and Cyprus during the 4th and the 7th centuries AD and had a large distribution throughout the Mediterranean, Aegean, the Black Sea and even as far as the Atlantic. While some commentators have suggested that they sometimes contained olive oil, recent analysis by gas-chromatography has reconfirmed that most probably carried wine (Williams 2005, 161). Only one rim (74) might tentatively be attributed to the latest variant of LRA 1 (6th-7th centuries AD), but it might alternatively be from a small, globular amphora, a type that frequently occurs in the Mediterranean from the 7 th to 9 th centuries AD.

The other eastern Late Roman amphorae of Riley's classification (LRA 3, 4, 5/6) are few in number and of uncertain identification. Some fragments might be attributed to the LRA 5/6, a bag-shaped amphora that was produced in Palestine and northern Egypt and occurred mainly in the eastern Mediterranean (Pieri 2005, 114-127). A rim (77) may be consistent with the latest derivations of LRA 5 of Ummayad date (7th-8th centuries AD). Few and dubious (e.g. 81) are the occurrences of another common Palestinan product, LRA 4 (Pieri 2005, 101-114), that had a wide distribution across the Mediterranean basin and may have contained the famous wines of Gaza (although recent analysis has demonstrated that these amphorae also carried olive and sesame oils: Pieri 2005, 111). Some further bases and handles (e.g. 78-79) in a hard dark brown fabric typical of Nile clays may be from examples of LRA 7, a wine amphora produced in Egypt throughout the 4th and the 7th-8th centuries AD. It is also worth noting that examples of western Anatolian production (LRA 3 and Samos Cistern Type) are very scarce in the survey assemblage.

The most widespread African Late Roman types in the Mediterranean are also present 
in the Antikythera survey material, though in limited numbers. They are characterized by a brick-red or orange clay that is rich in aeolian quartz, and by a white or cream external surface resulting from the use of saline water. The large cylindrical Keay 61 and $62(68-70)$ produced in the regions of Byzacena and Zeugitana throughout the late 5th and the 7th century AD are the most common African amphorae on Antikythera. Keay 34 and 35 (66-67) are far less common, and Keay 55 is possibly represented by a single body sherd. The contents of these amphorae are uncertain; a recent study (Bonifay and Garnier 2007) re-examined the issue using chemical analysis and suggested that olive oil may not have been as dominant as traditionally thought(with garum or wine being plausible alternatives for type Keay 62).

Italian Late Roman mphorae do not seem to be clearly represented in the survey assemblage. The fabric of a flat base with a concave indentation (80) may be consistent with a Castrum Perti amphora, whose place of origin was North Africa or the Near East, but such a base characterized various types of 5th and 6th century amphorae in the central and eastern Mediterranean.

\subsection{COARSE WARES (FIGS.10-12)}

As noted above, coarse wares represent a suprsingly small proportion of the Roman assemblage from Antikythera (31-37\%) and are only diagnostic of specific sub-phases in a limited number of cases. Despite this, at least some are certainly of Late Roman date, with cooking pots (95-99) and basins $(\mathbf{8 2}, \mathbf{8 5 - 8 6})$ being the best represented shapes, and bowls (88), jugs (93) and casseroles (100-101) present but less common. Among the cooking pots and the basins, the best-represented types have clear morphological similarities with those commonly attested in Late Roman Crete (especially at Knossos, Gortyn and Eleutherna), and for which a range of different fabrics have been identified. At present it is not possible to suggest a definite Cretan (or other) origin for the Antikytheran examples, but their fabric is very coarse and hard-fired, light red in colour and rich in medium to large white inclusions (perhaps a combination of quartz, mica and calcite), while the basins are made in a finer and softer reddish yellow clay, with fewer, smaller inclusions and scarce mica.

\section{DISCUSSION}

The above discussion has focused on describing the functional categories, shapes and sub-types present in the Antikytheran survey assemblage. Two more general absences during the Hellenistic and Roman phases on the island that are also worth noting are the very limited number of roof-tiles (particularly clear in the Hellenistic) and nearcomplete lack of identifiable large storage jars (e.g. pithoi) other than amphorae. It is possible that organic materials were used for roofing instead and that the abundance of maritime transport containers was a suitable substitute for large-scale household storage. Turning briefly to spatial patterning, and as already noted above, the Early Roman period (in ASP terms, from the first to second century AD) is hard to explore as a clear distribution of material across the landscape because the chronological range of many of the diagnostics overlaps with the period of occupation on the Hellenistic Kastro (late 4th century to mid 1st century BC, see Johnston et al. in preparation) and indeed are found on or near it. Most of the material relevant to the $1^{\text {st }}$ century $\mathrm{BC}$ consists of unstamped amphorae to which it is impossible to assign close 
historical dates. The Antikythera shipwreck does have material that is similar to that from the latest period of substantial occupation on the Kastro, but on the island itself material dating prior to the later $1^{\text {st }}$ century $\mathrm{BC}$ is very sporadic beyond the highly nucleated zone around the Kastro, making it clear that the distribution of Roman, and especially Late Roman, activity represents an entirely different social and economic phenomenon. The few fragments of Late Republican amphorae (i.e. Late Rhodian and Koanian types, Dressel 1, Lamboglia 2, Dressel 2-4, Dressel 6) come from different production areas in Italy and the Aegean, and their limited number does not allow us to identify any obvious similarities or differences with the pottery found in the neighbouring regions. However, it is worth noting that the limited presence of Italian wine amphorae on Antikythera may reflect a localised phenomenon observed in immediately neighbouring areas such as Crete (e.g. at Gortyn) while at the same time running counter to the overall pattern of increasing amounts of Italian wine amphorae in the wider Aegean after the fall of Corinth and Carthage (e.g on Delos). In contrast, the paucity of Late Punic and Roman Imperial African amphorae on Antikythera conforms with a more general trend that suggests a limited presence of African amphorae in the Aegean up to at least the 4th century AD.

For the Early and Middle Roman phases (in ASP terms, from the third to fourth century AD), our interpretation is constrained by the fact that some of the material that might be of this date also spans longer time ranges, and hence is not wholly diagnostic. Even so, there is certainly a small amount of material that is undeniably Early and Middle Roman and this clusters around the Xeropotamos and Potamos harbours, probably suggesting that limited visitation by passing ships and occasional habitation were the prevailing patterns of island exploitation rather than widespread occupation. We stress below, however, that such a conclusion is biased by the very skewed nature of our chronological indicators and should be treated with caution. Nevertheless, the pottery of this date from Antikythera includes some of the main shapes and amphora types attested in the central Aegean and seems to emphasise close relations with Crete whose trade containers are particularly well-attested.

For the Late Roman period (in ASP terms, from from the late 4th or the start of the 5th century to the 7th century $\mathrm{AD}$ ), we can document a range of denser clusters of surface material (FIG.1), often accompanied by small groups of contemporary cist graves, each at the heart of a more fertile region of the island. Most of these appear to be relatively small hamlets (and/or looser spatial groupings of farmsteads) of perhaps several families at most, but one above the modern town of Potamos (FIG.1b: location 1512) suggests a much larger village. Some Late Roman evidence from the Xeropotamos harbour suggests its continued importance during this period (e.g. FIG.1b: location 1506), but the Potamos harbour may have been increasingly dominant, especially given the suspicion that a combination of tectonic uplift and alluvial build-up would have made the former increasingly difficult to use. A preliminary assessment of the assemblages from individual Late Roman scatters around the island does not offer clear evidence for functional, chronological or warespecific differentiation, suggesting that most communities on the island had access to comparable kinds of ceramics over most of the Late Roman period, and were probably using them for similar purposes. Other finds from the Late Roman scatters include glass vessels and some probable groundstone tools (though the latter were not chronologically diagnostic and only attributed to this period circumstantially because of their findspots). 
The pottery evidence, at first glance, therefore suggests an episode of recolonisation and far more substantial activity during the Late Roman period. This pattern is partly the result of the higher visibility of Late Roman body sherds, with the perceived rate of change in quantities of sherds being very dependent on what kind of evidence we include (e.g. the 'factor increase' shown in Table 4, following the method suggested in Pettegrew 2007, 771-775), but in all cases it demonstrates much activity in Late Roman times and there is a real risk that we also overestimate earlier periods due to overlap with the period of occupation of the Hellenistic Kastro as noted above. In contrast, the end of this period of activity on the island is fairly clear-cut, with very little or no identifiable material after some time in the $7^{\text {th }}$ century $\mathrm{AD}$ until the $12^{\text {th }}$ century AD (Vroom, Bevan and Conolly in prep.), suggesting almost complete abandonment for a period of 400-500 years.

\begin{tabular}{|l|l|l|l|}
\hline Diagnostics & $\begin{array}{l}\text { Early/Middle } \\
\text { Roman }\end{array}$ & Late Roman & $\begin{array}{l}\text { Factor } \\
\text { Increase }\end{array}$ \\
\hline All sherds & 130 & 1278 & 10.1 \\
\hline RBaH & 120 & 428 & 3.5 \\
\hline RBa & 83 & 110 & 1.3 \\
\hline
\end{tabular}

Table 4. Comparison of factor increases between the Early/Middle and Late Roman periods for (i) all sherds (ii) rims, bases and handles $(\mathrm{RBaH})$ and (iii) rims and bases only $(\mathrm{RBa})$.

The Late Roman pottery assemblage also suggests economic and cultural links primarily with the Aegean (perhaps the Argolid in particular) and the eastern Mediterranean (mainly western Anatolia), as emphasised by the great quantity of LR1-2 amphorae and Phocaean RS wares, while Palestinian and Egyptian products are rare except for a few LR 5/6 and 7 amphorae. The paucity of Palestinian amphorae contrasts with the general pattern in the wider Aegean where these vessels are widely documented at numerous sites such as Argos (from the 4th century AD: AbadieReynal 2007, 271) and Corinth (mainly LRA 5/6 and 4 types: Slane 2000, 304-305). The direct relationship with Crete appears far stronger in late Hellenistic or earlier Roman phases than in later ones; more precisely, Late Roman Cretan amphorae are possibly present in very small numbers but very rare on the island (though worth noting more generally that these were generally not exported types; Portale 2004). The low frequency of the large cylindrical amphorae during the late 5th to the first half of the 7th century $\mathrm{AD}$, also suggests that the island was only a minor participant in a system of exchanges that can otherwise be documented linking the western Mediterranean with eastern Mediterranean centres such as Constantinople in the Late Roman period (see Bonifay 2004, 480ff.). However, as Bonifay notes $(2004,446)$, the lower numbers of African amphorae in the 5th century AD compared to the large numbers of contemporary Aegean and eastern Mediterranean containers may not actually indicate a decline in the amounts of traded African products circulating (i.e. in the amounts of product contained within the amphorae) because the former had a far larger capacity than the latter. In other words, the raw frequencies of pottery containers from these different regions needs to be carefully calibrated with regard to their varying capacities and due attention paid to whether they arrived at their point of archaeological deposition still containing their original contents or via secondary 
channels of re-use (see below). Moreover, it is worth emphasizing that the distribution pattern of the African amphorae is different from that of the ARS wares (with the former being far less frequently attested than the latter in the Aegean), suggesting that African amphorae and fine wares probably followed different trade routes and catered for different markets (Abadie-Reynal 2007, 158-159). In the case of Antikythera, the chronological range of ARSW exhibits a slightly different pattern from neighbouring areas: ARSW fabric C, which is otherwise very popular in the southern Aegean and on mainland Greece (i.e Crete, Argos, Corinth, Athens), exceeding the amount of eastern fine wares at some sites, is scarcely attested on our island where ARSW is only really documented for the $5^{\text {th }}$ century $\mathrm{AD}$. Furthermore, the latest types of ARSW are not found on Antikythera, despite being otherwise frequent throughout the Aegean in the 7th century AD. In contrast, the predominance of the Phoecean fine wares in the Antikythera assemblage during the $5^{\text {th }}$ to the $7^{\text {th }}$ century AD is entirely consistent with a more general trend in the Aegean and the eastern Mediterranean, in terms of the popularity of local and regional industries which produced red-slipped fine wares whose forms were often derived from the ARSW and PRSW.

The Late Roman finds from Antikythera can also perhaps be fitted into a wider emphasis on Aegean coastal sites in important maritime positions during this phase (Pettegrew 2007, 774). Moreover, the closeness of Crete had probably important effects in the economy and in the distribution of commodities in the small island. In fact it was noticed how there was in Gortyn an increase of amphora imports (mainly LRA 2) and a decrease in local productions through the 4th and the 8th centuries AD (Portale, Romeo 2001). The presence of African amphorae has led to the supposition that Crete played an important role along the east-west long-distance route in order to redistributethe African products in the Aegean and, perhaps, in the south-eastern Mediterranean after the end of Vandal rule and the Byzantine recovery of the western empire (i.e. the second half of the 6th century AD). As discussed above, this long distance trade route emerged rapidly with the rise of Constantinople in the 4th century $\mathrm{AD}$, in relation to the state-dominated supply of the eastern regions of the Empire with North African grain (i.e. the annona). From the 5th century AD, exports of goods from the east to Italy and North Africa also increased, as the conspicuous evidence of Palestinian and western Anatolian amphorae, as well as Phocaean fine wares, suggests (Abadie-Reynal 2007, 173-174). This phenomenon seems to have mainly affected the southern Aegean, especially Crete where African sigillata are attested in large numbers at various sites during the 6th century AD (Sparta, Athens, Kenchreai). In the second half of the 6th to the 7th century $\mathrm{AD}$, only the main economic and political centres in the east (e.g. Antioch, Constantinople) exhibit a significant interest in African commodities (Abadie-Reynal 2007, 153-157) and there is evidence for increasing regionalism in exchange patterns (Slane and Sanders 2005, 290).

It is possible that specific historical events are behind these phenomena, and it is not inconceivable that the imported commodities documented by the Antikytheran material reflect the direct intervention of the Byzantine central administration and even the establishment of a strategic outpost on the island (see Pettegrew 2007, 778). This is especially true given suspicions we have from our field reconnaissance that some of the walls on the plateau south of the modern village of Potamos (centred on $706420 \mathrm{E}, 3972720 \mathrm{~N}$ in UTM WGS84 zone 30N) may originally represent efforts at Late Roman fortification (or at the very least more substantial, non-domestic construction), though no clear-cut proof is forthcoming. In contrast, an alternative 
explanation is proposed by Lund (2007) who has suggested that the amphorae from a survey of the Akamas peninsula in western Cyprus, rather than reflecting primary consumption of the amphora contents, may have been re-cycled as milk or water containers for the needs of local farmers and shepherds. This explanation is particularly possible for Late Roman 1 amphorae that have a low capacity, but the secondary storage hypothesis may conceivably also be relevant for larger capacity vessels that might have stood in for pithoi in some households (the latter being a shape that we have not been able to identify with any confidence for the Late Roman period on the island).

Many of these remaining uncertainties outline possible opportunities for further study, but what this paper still provides is one of the first systematic studies of a spatially 'comprehensive' assemblage from a Mediterranean island. Antikythera's comparatively remote location and seemingly discontinuous history of permanent occupation implies a contingent and variable engagement with the wider geopolitics of the Roman world and therefore offers a useful point of analytical comparison and contrast to Roman assemblages recovered from more mainstream locations.

\section{CATALOGUE OF ILLUSTRATED SHERDS}

The sherds in this catalogue are numbered in bold with a sequence unique to this publication. Field numbers in most cases are indicated in brackets (e.g. "8130-28-165-8"), providing a unique identifier of the stage-one survey unit, surveyor, distance walked and sherd number within the unit (technically "tract-walker-pass-distancesherd"). In one case (41), the catalogued sherd comes from finer-scale, stage-two collection (applied to mainly prehistoric scatters). In this case, the field number takes the form of "0075-7135-S-37" which is a unique identifier comprising a grid square ID (0075-7135), an indication of the collection stage (S) and sherd number (37). These field numbers are the ones physically marked on the finds or finds bags and are also used in other ASP publications. A location for each potsherd is provided in metres (UTM zone 34N, WGS84, see FIG. 1), with a working accuracy typically within $10 \mathrm{~m}$. All other measurements are in centimetres.

\subsection{FINE WARES}

1 (8130-28-1-65-8) 706599E, 3973079N

Cup, rim. ESC ware. Curved and indistinct on the top portion of the rim and hemispherical body: ESC form H 4 or type Meyer-Schlichtmann NA 12. D. $22 \mathrm{~cm}, \mathrm{H}$. $2.7 \mathrm{~cm}$. Fine and soft reddish-yellow (5YR 6/8), fabric with few white small inclusions; sharp and smooth fracture. Traces of red slip (10R 5/6) are badly preserved in the interior surface(?). References: Atlante II, 78, pl. XVIII.4 (end of $2^{\text {nd }}-$ $3^{\text {rd }}$ century AD); Meyer-Schlichtmann 1988, 98. pl. 11. See also a Sagalassos Red Slip cup, of which several variants appear in the second half of the 1st century to the 3rd century AD: Poblome 1999, 304, type 1A100, fig. 5. Date: End of the 2nd to the 3rd century $\mathrm{AD}$ (Meyer-Schichtmann dates the type from the end of the 1st century BC to 50AD).

2 (4268-18-1-5-1) 707067E, 3972005N

Plate, rim, unidentified ware and type. D. $34 \mathrm{~cm}, \mathrm{H} .7 \mathrm{~cm}$. Fine and friable red (5YR 
6/6) fabric, with a few small, white inclusions; sharp and smooth fracture of the section. Interior and exterior red slip, badly preserved (10R 5/6). References: The fragment recalls ESA form 6, which was attested from the late second century BC to ca 20-1 BC: Atlante II, 17, pl. II, no. 3-4. See also Kenrick 1985, 227, n. 316.2, fig. 41 (Augustan age). A similar form was present in Sagalassos Red Slip ware from the second half of the first century AD to the third century AD: Poblome 1999, 308, variant 1C132, fig. 57.4. Date: 1 st to 3rd century AD.

Author uses inner and outer in several instances-would interior and exterior be better?

\section{3 (3177-6-1-95-1) 705350E, 3974509N}

Bowl, thick vertical rim and truncated-conical body. Imitation of ESB form 60. D. not measurable, H. $4 \mathrm{~cm}$. Fairly fine and hard reddish-yellow (7.5YR 6/4) fabric, occasional inclusions of small and medium size. Outer red (10YR 5/6) and inner black slip. References: The ESB form is dated among 50 BC early 3rd century AD (Hayes 2008, 39, no. 345-374, from the Athenian Agora). See also Slane 1990, 49-50, no. 94, fig. 6 (Corinth, first half of the 2nd century AD). An imitation in local buff ware is attested from the excavations of the Villa Dionysos at Knossos: Hayes 1983, 122, fig. 10, no. 122 (2nd-3rd century AD?). Local imitations and variants of this type are also present in Athenian assemblages from the late $1^{\text {st }}$ to the second half of $3^{\text {rd }}$ century AD: Robinson 1959, 40-41, 54, 61, 74, G 173-G174, J 32, K 13, L 1, pl. 67-68 and 70. Date: 2nd to 3rd century AD.

\section{4 (3394-12-1-15-1) 707876E, 3972374N}

Bowl, rim. ARS ware (production C), type Hayes 82A. D. $32 \mathrm{~cm}, \mathrm{H} 4 \mathrm{~cm}$. Fine and hard orange (2.5YR 6/8) fabric, sporadic small white inclusions; sharp and smooth fracture of the section. Outer and inner dull red slip, which is very similar to the colour of the clay. References: Hayes 1972, 129, fig. 23, 2; Atlante I, pl. XXIX. 9-11 (430-500 AD). It is the most attested type of the production $\mathrm{C}$ in Argos: AbadieReynal 2007, 160-161, nos. 264-266, pl. 38. Date: 430-475 AD.

\section{5 (3678-34-1-5-4) 708296E, 3970282N}

Bowl, rim. ARS ware (production D), type Hayes 50. D. $38 \mathrm{~cm}, \mathrm{H} .3 .3 \mathrm{~cm}$. Very fine and hard orange (2.5YR 6/8) fabric, occasional small and white inclusions (quartz?); sharp and smooth fracture of the section. Outer and inner dull red slip; its colour is the same as that of the clay. References: Atlante I, 86, pl. XXXVII. 1. Date 350-400 AD.

\section{$6(5127-2-1-5-1) 708764 \mathrm{E}, 3973459 \mathrm{~N}$}

Plate, rim; ARS ware (production D), type Hayes 67. No. 1, 4, 9. D. $36 \mathrm{~cm}, \mathrm{H} .1 \mathrm{~cm}$. Very fine and hard orange (2.5YR 6/8) fabric, scarce small and white inclusions (quartz?); sharp and smooth fracture of the section. Outer and inner dull slip, badly preserved; its colour is as the same as that of the clay. References: Atlante I, pl. XXXVII. 9. The type is attested in an assemblage dating to the first quarter of the 5th century AD at Argos: Ivantchik 2002, 378, no. 107, fig. 14. Date: 360-470 AD. Bonifay $(2004,171-172$, fig. 92, 6) identified this type as a variant which was very common mainly in the first half of the 5 th century AD.

\section{7 (12294-58-1-15-1) 709958E, 3969685N}

Bowl, rim. ARS ware (production D), variant of the Hayes type 87A? D. $38 \mathrm{~cm}, \mathrm{H} 2.5$ 
$\mathrm{cm}$. Very fine and hard orange (2.5YR 6/8) fabric, scarce small and white inclusions (quartz?); sharp and smooth fracture of the section. Thick and dull slip on the surfaces; its colour is that of the clay. References: Atlante I, pl. XLI, 5- 7; Bonifay 2004, 173-175. Date: Second half of the 5th century AD.

8 (7135-25-1-45-1) 708257E, 3972080N

Bowl, rim. ARS ware (production D), type Hayes 99 A-B. D. $20 \mathrm{~cm}$, H. $3.2 \mathrm{~cm}$. Very fine and hard orange (2.5YR 6/8) fabric, scarce small and white inclusions (quartz?); sharp and smooth fracture of the section. Outer and inner dull slip, badly preserved; its colour is that of the clay. References: Atlante I, pl. L, no. 11-15, pl. LI, no. 1-6; Bonifay 2004, 181. Date: 510-580 AD. The most recent variant of this type dates back to the end of the 6th-early 7th century AD. Hayes 2008, 232, no. 1155, fig. 36.

9 (4074-5-1-5-1) 706416E, 3972253N

Plate, rim. ARS ware, type Hayes 104 (?). D. $38 \mathrm{~cm}$, H. $1.7 \mathrm{~cm}$. Quite fine and hard orange (2.5YR 6/8) fabric, occasional small, white inclusions (quartz?); sharp and smooth fracture of the section. Occasional traces of slip. References: Atlante I, 96, pl XLIV, 3; Bonifay 2004, 181-183 (variant B) fig. 97. 34, Date: This type is attested from 550 to $650 \mathrm{AD}$. This fragment may be attributed to the late variant of the 7 th century (Hayes type 104.22).

$10(3680-42-1-5)$

Plate, rim. ARS ware (?), type Hayes 105. D. $34 \mathrm{~cm}$, H. $2 \mathrm{~cm}$. Quite fine and soft fabric (2.5YR 5/6), few small inclusions (quartz, mica?); sharp and rough fracture of the section. The slip is almost completely lost. References: Hayes 1972, 167, fig. 31, n. 17; Atlante I, 96, pl. XLIV, 1-2. Date: End of the 6th century to 650 AD.

\section{1 (8115-36-1-55-1) 709286E, 3970745N}

Plate, base with a vertical and high foot, not identified ware and type (ARS?). Multiple rouletting decoration on the inner surface and not identified motif in the centre. D. $19 \mathrm{~cm}$, H. $2.7 \mathrm{~cm}$. Very fine and hard fired fabric $(2.5 \mathrm{Y} 7 / 1)$, occasional small white and gray inclusions (quartz?); sharp and smooth fracture of the section. Thick light-brown slip on both of the surfaces. References: the high and vertical foot recalls those of some ARS types (Hayes 104 and 105); while the multiple rouletting decoration is consistent with motifs frequently attested on some forms of Late Roman Phocaean Ware: see Gandolfi 2005. Date: 5th -6th centuries AD.

12 (3680-42-1-15-2)

Bowl, rim. PRS ware, form 1A. D. $18 \mathrm{~cm}, \mathrm{H} 2.7 \mathrm{~cm}$. Very fine and hard orange (2.5YR 6/8) fabric, occasional small white and yellow inclusions; sharp and smooth fracture of the section. Dull red slip (2.5YR 5/8), badly preserved on both surfaces. References: Martin 1998, fig. 1, Form 1A, no. 1-2; Gandolfi 2005, 234, pl. 1, form 1A. Ladstätter 2005, 168, pl. 1, 6 (from Ephesus, late 4th century AD). Date: Late 4th to the beginning of the 5th century AD.

\section{3 (7129-40-1-25-1) 708384E, 3972050N}

Bowl, rim. PRS ware, form 1B. D. $26 \mathrm{~cm}$, H. $2.2 \mathrm{~cm}$. Very fine and hard orange (2.5YR 6/8) fabric, occasional small white and yellow inclusions; sharp and smooth fracture of the section. Dull red slip (2.5YR 5/8), badly preserved on both of the surfaces. References: Martin 1998, fig. 1, Form 1B, no. 3; Gandolfi 2005, 234, pl. 1, 
form 1B; Ladstätter 2005, 168, pl. 1, 4 (from Ephesus). Date: End of the 4th to the third quarter of the 5th century AD.

14 (4222-29-1-35-1) 706813E, 3972244N

Bowl, rim. PRS ware, form 1D. D. $34 \mathrm{~cm}, \mathrm{H} 1.8 \mathrm{~cm}$. Very fine and hard orange (2.5YR 6/8) fabric, small white and yellow inclusions in small quantities; sharp and smooth fracture of the section. Dull red slip (2.5YR 5/8), badly preserved on both of the surfaces. References: Martin 1998, fig. 1, Form 1, no. 7; Gandolfi 2005, 234, pl. 1, form 1D; Ladstätter 2005, p. 168, pl. 1, 7 (from Ephesus, late 4th century AD). Date: Early to third quarter of 5 th century AD.

15 (17005-103-1-35-1) 707892E, 3972407N

Bowl-plate, rim. unidentified ware (PRS?). Multiple rouletting decoration on the inner profile of rim. D $34 \mathrm{~cm}$, H. $1.5 \mathrm{~cm}$. Very fine and hard fired grey (10YR 6/3) fabric; sharp and smooth fracture of the section. Dull reddish-yellow slip (7.5YR 6/6), poorly preserved. References: the rim shape is very similar to that of PRS form 2 (Martin 1998, fig. 1; Gandolfi 2005, 234-235, pl. 1, form 2A); but the decoration, while quite common on some ARS and PRS types, is not otherwise attested for PRS form 2. Date: $370-450 \mathrm{AD}$

$16(4076-14-1-15-3)$ 706348E, 3972451N

Bowl-plate, rim. PRS ware, form 2A. D. $30 \mathrm{~cm}, \mathrm{H} .1 .6 \mathrm{~cm}$. Very fine and hard red (2.5YR 6/6) fabric, small white and yellow inclusions in sparse quantities; sharp and smooth fracture of the section. Dull and quite thick orange slip (2.5YR 5/8). References: Martin 1998, fig. 1, Form 2, no. 1; Gandolfi 2005, 234-235, pl. 1, form 2A; Ladstätter 2005, 169, pl. 1, 16 (from Ephesus, late 4th to the first half of the 5th century AD). Date: 370-450 AD.

\section{7 (8019-36-1-55-2) 709106E, 3971243N}

Bowl, rim. PRS ware, form 3C. D. $22 \mathrm{~cm}$, H. 1-7 cm. Very fine and hard orange (7.5YR 5/4) fabric, small white and yellow inclusions in sparse quantities; sharp and smooth fracture of the section. Thin and not uniform orange slip (2.5YR 6/6). References: Martin 1998, fig. 2, Form 3C, no. 7; Gandolfi 2005, 235, pl. 1, form 3C; Ladstätter 2005, 170, pl. 3, 32 (from Ephesus, 5th century AD). Date: 450-480/490 AD. Recently Hayes $(2008,87-88)$ dates form 3 from the early 5 th to the third quarter of the 6th century AD.

\section{8 (8231-26-1-5-1)}

Bowl, rim. PRS ware, form 3B. Multiple rouletting decoration on the outer face of the rim. D. $32 \mathrm{~cm}$, H. $3 \mathrm{~cm}$. Very fine and soft fabric (10YR 8/4), occasional small white and yellow inclusions; sharp and smooth fracture of the section. The slip is not preserved. References: Hayes 1972, 331, fig. 67, no 5. For the decoration see also: Gandolfi 2005, pl. 6A (from Cerro de Montroy); Ladstätter 2005, 172, pl. 4, 46 (from Ephesus, 6th century AD). Date: 450-480/490 AD. See no. 17

$19(6003-2-1-5-1) 708267 \mathrm{E}, 3971727 \mathrm{~N}$

Bowl, rim. PRS ware, form 3B-C. One line of rouletting decoration on the outer surface of rim. D. $33 \mathrm{~cm}, \mathrm{H} .3 .5 \mathrm{~cm}$. Very fine and hard fabric $(2.5 \mathrm{YR} \mathrm{6/6})$, occasional small white and yellow inclusions; sharp and smooth fracture of the section. Orange slip (2.5YR 6/8), thick on the inner surface and thin on the outer one. 
References: Hayes 1972, 331, fig. 67, no 5. For the decoration: Hayes 1972, 333, fig. 68, no 14; Ladstätter2005, 172, pl. 4, 50 (Ephesus, 5th century AD); Hayes 2008, 240, no. 1266, fig. 39 (Athens, third quarter of the 5th century AD). Date: see no. 18

20 (3393-16-1-85-1) 707834E, 3972323N

Bowl, rim. PRS ware, form 3 (E?). One line of rouletting decoration on the outer face of rim. D. $29 \mathrm{~cm}$, H. $2.5 \mathrm{~cm}$. Very fine and hard fabric (2.5 YR 6-8), sparse quantities of small white and yellow inclusions; sharp and smooth fracture of the section. Thin and badly preserved orange slip (2.5 YR 6-8). References: Martin 1998, fig. 3, Form 3E, no. 15; Gandolfi 2005, 235, pl. 2, form 3E. For the decoration: Ladstätter 2005, 171, pl. 3, 34 (Ephesus, 5th century AD); Hayes 2008, 243, no. 1296, fig. 40 (Athens, late 5th century to 500 A.D.); Rizzo 2001, 59, pl. X, f (Gortyn, late 5th century AD). Date: Second half of the 5th to the beginning of the 6th century AD.

$21(8113-20-1-45-1)$

Bowl, rim. PRS ware, form 3 (E?). D. not measurable, H $2.5 \mathrm{~cm}$. Very fine and hard fired fabric (10 YR 5-1), sparse quantities of small white and yellow inclusions; sharp and smooth fracture of the section. Reddish-brown slip partially preserved on the outer surface. References: Martin 1998, fig. 3, Form 3E, no. 15; Gandolfi 2005, 235, pl. 2, form 3E; Ladstätter 2005, 173, pl. 5, 64 (Ephesus, variant of small size, 5th century AD). Date: Second half of the 5th to the beginning of the 6th century AD.

22 (7138-5-1-55-2) 708359E, 3972162N

Bowl, rim. PRS ware, form 3. Two close-set lines of deeply impressed rouletting decoration on the outside. D. $32 \mathrm{~cm}$, H. $2 \mathrm{~cm}$. Very fine and soft fabric $(2.5 \mathrm{YR} 6 / 8)$, sparse quantities of small, white and yellow inclusions; sharp and smooth fracture of the section. Few traces of the slip are present on the surface. References: Martin 1998, fig. 3, Form 3F, no. 23 (mainly for the decoration). For shape and decoration: Ladstätter 2005, 172-173, pl. 5, 54-56 (Ephesus, 5th century AD); Hayes 2008, 241, no. 1280, fig. 39 (Athens, from a context of second quarter of 6th century AD); Rizzo 2001, 59, pl. XI, e (from Gortyn, late 5th century AD); Dello Preite 1997, 174, n. 68, pl. XXV, 4 (from Gortyn), Date: Late 5th to the second quarter of 6th century AD.

\section{3 (6007-16-1-65-1) 708282E, 3971682N}

Bowl, base. PRS ware, probably related to shape 3 . Two bands of rouletting decorate the inner surface. D. not measurable, H. $1.6 \mathrm{~cm}$. Very fine and soft fabric $(2.5 \mathrm{YR} 6 / 6)$, sparse quantities of small white and yellow inclusions; sharp and smooth fracture of the section. A rather poorly preserved red slip (2.5 YR 6-8) is present on the surface. References: Martin 1998, fig. 3, Form 3, no. 2, 4 e 5. For the decoration Gandolfi 2005, 235, pl. 6, A (Cerro de Montroy, second half of the 6th century AD). Date: second half of the $5^{\text {th }}$ century to $550 \mathrm{AD}$.

24 (4020-17-1-15-5) 706682E, 3972759N

Bowl, rim. PRS ware, form 10A. D. $30 \mathrm{~cm}, \mathrm{H} .2 \mathrm{~cm}$. Very fine and soft fabric $(2.5 \mathrm{YR}$ 6/8), occasional small white and yellow inclusions; sharp and smooth fracture of the section. A few traces of a red slip are present on the surface. References: Martin 1998, fig. 5, Form 10, no. 4; Gandolfi 2005, 236, pl. 4, form 10A. Date: Late 6th to mid 7th century AD. New evidence from the Athenian Agora and other sites (Beirut) seems to shift the origin of this form a quarter of century earlier than the traditional date (Hayes 2008, 85-86). 
25 (10012-44-1-85-1) 706792E, 3971238N

Bowl, rim. PRS ware, form 10B-C. D. $28 \mathrm{~cm}, \mathrm{H} .2 .5 \mathrm{~cm}$. Very fine and soft fabric (2.5YR 6/6), sparse quantities of small white and yellow inclusions; sharp and smooth fracture of the section. A thin red slip is partially present on the surface. References: Martin 1998, fig. 5, Form 10C, no. 11; Gandolfi 2005, 236, pl. 4, form 10C; Ladstätter 2005, 176, pl. 7, 91-92 (Ephesus, 6th century AD). Date: First half of 6th to 600 AD. See also no. 24

\section{6 (4042-18-1-65-1) 706426E, 3972850N}

Bowl, rim. PRS ware, form 10C. D. $28 \mathrm{~cm}, \mathrm{H} .2 \mathrm{~cm}$. Very fine and soft fabric $(2.5 \mathrm{YR}$ 6/6), scarce and small white and yellow inclusions; sharp and smooth fracture of the section. A thin red slip (2.5YR 6/6) is partially present on the surface. References: Martin 1998, fig. 5, Form 10C, no. 11; Gandolfi 2005, 236, pl. 4, form 10C. Date: First half of the 7th century AD. See also no. 24

\section{7 (12042-57-1-25-6) 709633E, 3970359N}

Bowl, base. PRS ware, unidentified type. Decoration with stamped "Star of David" motif, relative to Hayes's Group II. W. $3.5, \mathrm{H} .0 .5 \mathrm{~cm}$. Very fine and soft fabric (2.5YR 6/8), a sparse quantity of small white and yellow inclusions; sharp and smooth fracture of the section. Few traces of a red slip (2.5YR 6/8) are present on the surface. References: Hayes 1972, p. 351, fig. 73, motif 6a-b, which occurred between 440 and 490 AD. Date: 450 to the end of 5th century AD.

28 (4035-10-1-35-1) 706557E, 3972836N

Plate, rim. RS ware not identified. The rim, the top of which is flat, is thickened on the exterior and rounded; the vessel wall slopes vertically. D. $36 \mathrm{~cm}, \mathrm{H} .3 .2 \mathrm{~cm}$. Very fine and soft fabric (7.5YR 8/4) with a sparse frequency of small inclusions; sharp and smooth fracture of the section. Traces of a thin red slip are present on both surfaces. References: The shape of this plate recalls the ARS types 104-105 and the PRS Form 10 generally: Hayes 1972, 167, fig. 31, no. 3, 6, 7, 10 (ARS form 105) and 343, fig. 71, no. 15 (PRS form 10). Similar to the "local-regional" RS dish from a seventh century AD context at Knossos: Hayes 2001, 445, no. B8, fig. 6. Some brown slipped and unslipped imitations of the ARS ware are attested in the early 7th century at Gortyn (Crete): Albertocchi and Perna 2001, 422, type BIII 3.4-1, pl. LXXXVI; Albertocchi 2004, 992, fig. 1, d. See also an unslipped imitation of a PRS shape from Eleutherna (Crete): Yangaki 2005, 80, no. 391, fig. 10.e. Date: Late 6th to the 7 th century AD?

\section{9 (3623-42-1-5-1) 708420E, 3970270N}

Plate, rim. RS ware not identified. Knobbed and rounded rim with a slight external projection; grooves on the exterior surface of the oblique wall close to the rim. D. not measurable, H. $1-5 \mathrm{~cm}$. Very fine and soft fabric (7.5YR 7/6) with a sparse quantity of small inclusions; sharp and smooth fracture of the section. A few traces of a thin brownish slip (2.5YR 4/2) are present on both the surfaces. References: The shape of this plate is reminiscent of the ARS type 104: Hayes 1972, 163, fig. 30, no. 15. An unslipped imitation of the ARS Hayes 104 is also attested in the 6th and the 7th centuries AD at Gortyn (Crete): Albertocchi and Perna 2001, 419, type AIII 3.1-1, pl. LXXXIV; Albertocchi 2004, 992, fig. 1, C. Date: Late 6th to 7th century AD? 
30 (4298-20-1-35-8) 707194E, 3973959N

Plate, rim. RS ware not identified: broad flat rim rising to a vertical and rounded lip. D. not measurable, H. $2.5 \mathrm{~cm}$. Very fine and soft fabric $(10 \mathrm{YR} 6 / 3)$ with a low frequency of small inclusions (mica?); sharp and smooth fracture of the section. Scarce traces of a thin brownish slip (2.5YR 4/2) are preserved. References: It could be an imitation of ARS ware, type Hayes 76: Hayes 1972, 124-125; Atlante I, 89-90, pl. XXXVIII, no 6-10. Date: 425-475 AD.

\section{1 (4034-10-1-65-1) 706597E, 3972903N}

Plate-bowl, rim. RS ware not identified. Knobbed and oblique rim with sloping wall; the top of the rim is flat. D. $30 \mathrm{~cm}, \mathrm{H} .1 .8 \mathrm{~cm}$. Very fine and soft fabric $(7.5 \mathrm{YR} 6 / 3)$ with a sparse quantity of small inclusions (mica?); sharp and smooth fracture of the section. A thin, dull and uneven red slip (2.5YR 6/8) is badly preserved. References: This sherd generically recalls the morphology of some late types in ARS, PRS and LRD wares; e.g. see a Cypriot Red Slip dish from Paphos, which was discovered in a context of the second half of the 7th century AD (Hayes 2003, 495, no. 275, fig. 28). See also some similar 'local-regional' RS dishes that are attested in the Aegean and west Anatolian areas: Hayes 2001, p. 445, no. B6 fig. 6 (Knossos, from a seventh century cistern deposit); Robinson 1959, 14, F 36-F 37, pl. 65 and 30, G 82, pl. 67 (Athens, last quarter of the first to the second century AD); Firat 2000, 37, fig. 3 (Perge, after 630 AD). Date: Late 6th to the 7th century AD?

\section{2 (4003-10-1-45-5) 706605E, 3972655N}

Plate-bowl, rim. RS ware not identified. Knobbed and rounded rim with sloping wall; the top of the rim is horizontal and flat; D. 28 to $32 \mathrm{~cm}, \mathrm{H} .1 .5 \mathrm{~cm}$. Very fine and hard fabric (7.5YR 7/4) with a sparse quantity of small inclusions; sharp and smooth fracture of the section. A thin, dull and uneven red slip (2.5YR 6/8) is badly preserved. References: Similar to the PRS form 10A: Hayes 1972, 343, fig. 71, 2. Date: Late 6th to the 7th century AD?

\section{3 (4050-17-1-25-9) 706534E, 3972702N}

Bowl, rim and base. RS ware not identified. The rim is similar to that of the previous specimen but there are thin grooves along its horizontal flat surface. A base with a high foot is probably related to the rim. D. rim $29 \mathrm{~cm}, \mathrm{D}$. foot $14 \mathrm{~cm}, \mathrm{H} .2 \mathrm{~cm}$. Very fine and soft fabric (5YR 7/6) with occasional small inclusions; sharp and smooth fracture of the section. A thin, shiny and fairly uniform red slip (2.5YR 6/8) is preserved on both surfaces. References: This bowl is reminiscent of the shape of the ARS form Atlante I, pl. XLI, 3-4, which is a variant of the form Hayes 87A and C: Atlante I, p. 93, pl. XLI, 3-4. Date: second half of 6th century AD?

\section{4 (3459-19-1-75-1) 707871E, 3971924N}

Bowl, rim. RS ware not identified. The rim is triangular and grooved on the top; the wall is sloping. D. $24 \mathrm{~cm}$, H. $2 \mathrm{~cm}$. Very fine and soft fabric (5YR 7/6) with a low frequency of small inclusions; sharp and smooth fracture of the section. A thin, shiny and quite uniform red slip (2.5YR 6/8) is quite well preserved on both the surfaces. References: The rim is quite similar to a local imitation of the PRS ware form 10 at Eleutherna (Crete), from a context of the second half of the 7th century AD: Yangaki 2005, 124-125, fig. 9.c and 11.g (in plain ware). This fragment closely resembles form 7 of the Cypriote Red Slip Ware (LRD): see Kenkel 2007, 137, fig. 6 (from Pednelissos, Pisidia). Date: Late 6th to the 7th century AD. 
35 (12171-57-1-65-1) 709603E, 3970116N

Bowl, rim. RS ware not identified. Rounded and incurved rim, projecting from the wall on the top; sloping wall with grooves on the outer face. D. $28 \mathrm{~cm}, \mathrm{H} .2 .7 \mathrm{~cm}$. Very fine and quite hard fabric (7.5YR 7/4) with a low frequency of small inclusions; sharp and smooth fracture of the section. A thin, shine and fairly uniform red slip (2.5YR 6/8) is badly preserved on both the surfaces. References: The shape of the rim and the fabric recall forms 9 and 10 of Cypriot Red Slip Ware, dated from the second half of the 6th to the end of the 7th century AD, but the standard rouletting decoration on the outside is absent on the fragment from Antikythera; Hayes 1972, 379-383, fig. 81; Hayes 2008, 249, no. 1423, fig. 42 (Athens, early 6th century AD, corresponding to form 3 of Cypriot Red Slip Ware). Some similar bowls occurred in the 'localregional' RS of a seventh century context at Knossos, which were related to the ARS form Hayes 104-105t: Hayes 2001, 445, B11-B15, fig. 6. Date: 6th to 7th century $\mathrm{AD}$ ?

36 (4071-17-1-25-2) 706534E, 3972374N

Bowl, rim. RS ware not identified. This type is similar to the previous one but the rim projects further on the outside and is more rounded on its internal face. D. $32 \mathrm{~cm}, \mathrm{H} .1$ $\mathrm{cm}$. Very fine and hard fabric (7.5YR 7/4) with a small quantity of small inclusions; sharp and smooth fracture of the section. A few traces of a thin brownish slip (2.5YR 4/3) are badly preserved. References: Like the previous one, this type recalls the group of the 'local-regional' RS bowls attested at Knossos in a deposit of the 7th century: Hayes 2001, 445, B11-B12, fig. 6. This fragment is also quite similar to some sherds which were identified in the ARS type Hayes 104A: see a fragment from Olbia (Provence, France), which occurred in a context of the beginning of the 6th century AD: Bats, Andreau and Barbet 2006, 84, fig. 15, n. 8. Date: 6th to 7th century AD.

\section{7 (4256-39-1-60-1) 707001E, 3972245N}

Cup, rim. RS ware not identified. Vertical curved and pointed on the top. D. $19 \mathrm{~cm}$, H. 2,2 cm. Very fine and soft fabric (10YR 8/4) with a scarce quantity of small inclusions; sharp and smooth fracture of the section. The slip has completely disappeared. References: It may be an imitation or an unknown production of the PRS ware form 1A-B; Hayes 1972, 325-327, fig. 65. An imitation of PRS 1 is attested in the "ceramica ad engobbio rosso" which was identified in Italian excavations at Gortyn: Dello Preite and Martin 1997, 207, no. 24, pl. XXXVIII, 6. Date: late 4th to the third quarter of the 5th century AD.

38 (8040-20-1-5-1) 709033E, 3970587N

Cup, rim. RS ware not identified. D. not measurable, H. $1.4 \mathrm{~cm}$. Fine and hard fabric (10YR 8/4), occasional small and white inclusions; sharp and smooth fracture of the section. The red slip, which covered both faces, has almost completely disappeared. References: Similar to a bowl from a context of the 3rd century AD in Kythera: Coldstream and Huxley 1972, 166, fig. 50, 2. This sherd may have been a derivative from the ESC form L19 or form H3 or of western shapes. Some imitations of these forms are found at Athens, Argos and Gortyn: Robinson 1959, 41, G 175, pl. 67 (Athens, late 1st to early 2nd century AD); Abadie-Reynal 2007, 198-199, no. 324, pl. 47 (Argos, 2nd century AD); Dello Preite and Martin 1997, 208, no. 29, pl. XXXIX.2. Date: second half of the first century AD to the third century AD? 
39 (6745-1485-V-5) 706743E, 3971482N

Lamp, body. Palestinian ware? Curvilinear shoulder and raised rim of a pointed oval lamp; the lower part of the body was probably carinated. An incomplete, mould-made inscription in relief on the shoulder reads]ENEIПAC[ W. $8 \mathrm{~cm}, \mathrm{H} .1 .5 \mathrm{~cm}$. Fine and hard fabric (10YR 8/4) with occasional small and white inclusions; sharp and smooth fracture of the section. A thin and uneven red slip covers part of the surface. References: The complete text will have been $\Phi \Omega C$ XY $\Phi E N E I$ ПACIN ("The light of Christ shines for all"), a Greek inscription of religious character which was very common on Palestinian lamps of the 5th to the 6th century AD; $\Phi E N E I$ would have been a uncommon version of the word $\Phi$ AINEI (for the linguistic change of $\alpha \mathrm{l}$ to $\varepsilon$ in Roman times, see Threatte 1980, 294-9) The character of the clay also recalls the description of the Palestinian fabrics. See Bailey 1988, 107, 288, Q 2333 and 2334, pl. 60; Leclercq 1928, 1108-1109, no 55. See also for the attestations and the meaning of this inscription and for the distribution and the ritual use of these lamps: Leclercq 1928, 1108-1110, no. 55; Loffreda 1989, 39-47 and 79-120. This type of lamp does not seem to have been commonly attested in the Aegean area, with one other example being from the excavations at Saraçhane, Istanbul (Hayes 1992, 89, pl. 24, no. 124). Date: The first specimens of this lamp occur from the 4th-5th to 6th century AD.

\subsection{MARITIME TRANSPORT AND LARGE STORAGE JARS}

40 (4303-20-1-15-13) 707142E, 3974043N

Amphora, rim. Pascual 1 or DR 1B amphora?. D. $11 \mathrm{~cm}$, H. $6.8 \mathrm{~cm}$. Rough and hard red clay (10R 5/8) with frequent black inclusions and voids of small and medium size; a few large inclusions; sharp and rough fracture of the section. References: Peacock and Williams 1986, 93-95 (Pascual 1 amphora). Date: From the second half of the 1st century $\mathrm{BC}$ to the second half of the 1st century $\mathrm{AD}$, although the majority of datable finds from north-western Europe tend to be Augustan in date.

\section{1 (0075-7135-S-37) 710076E, 3967135N}

Lamboglia 2 amphora, rim. Quite fine and fairly soft reddish yellow clay (5YR 5-6/6) with occasional small inclusions and voids; sharp and rough fracture of the section. References: The Lamboglia 2 amphora was already attested in the cargo of Antikythera's shipwreck, which was dated to 80-70 BC: Grace 1965, fig. 1 (first from right). It also occurs at Corinth (Romano 1994, 88, nos. 67-69, fig. 13, pl. 26-27) and Ephesus (Bezeczky 2004, 88, fig. 1.6; Bezeczky 2006, fig. 6, 52). For an overview of this amphora see: Tchernia 1986, 53-56; Bruno 1995. Date: Second half of the 2nd to within the 1 st century BC.

42 (3392-12-1-55-2) 707927E, 3972221N

Lamboglia 2 amphora (?), base: the stub is not preserved. D. $2.3 \mathrm{~cm}, \mathrm{H} .5 .5 \mathrm{~cm}$. Quite fine and fairly soft clay (2.5Y 8/3 on the outer surface, 5YR $7 / 6$ on the core) with frequent white and reddish yellow inclusions, few voids; sharp and smooth fracture of the section. References: Cipriano and Carre 1989, 81, fig. 12, no. CM 14. (atelier of Cologna Marina, central Adriatic, Italy). Date: Second half of the 2nd to within the 1 st century BC. 
43 (1062-6-1-35-1) 707127E, 3973297N

Probable Dressel 6 amphora, base; the stub is not preserved. D. $4.5 \mathrm{~cm}, \mathrm{H} .7 .6 \mathrm{~cm}$. Quite fine and soft reddish yellow clay (7.5YR 7/6), with occasional white and black inclusions of small and medium size, rare mica; irregular and rough fracture of the section. The surface is very eroded. References: An overview of the productions and the distribution of the Dressel 6 amphorae is in Peacock and Williams 1986, 98-101, Bruno 2005, 375-376. Date: Late Augustan period to the end of the Hadrianic period (early first to the mid second centuries AD).

44 (1128-3-1-85-2) 707322E, 3973768N

Dressel 20 amphora, base. H. $3.2 \mathrm{~cm}$. Very rough and hard pink clay (7.5YR 8/4) with frequent and prominent white, grey and red inclusions; irregular and rough fracture of the section. References: An overview of this amphora is in Peacock and Williams 1986, 136-140. The occurrence of the Dressel 20 amphorae in the eastern Mediterranean is described in Will 1983 and in Portale and Romeo 2001, 286.

45 (1085-1-1-75-1) 707208E, 3973805N

Maña C1a-Van der Werff 3 amphora, rim. D. $15 \mathrm{~cm}, H .5 .7 \mathrm{~cm}$. Quite fine and soft light clay (2.5YR 6/8 on the core, light gray on the outer face) with frequent small yellow inclusions and few white grains; sharp and dusty fracture of the section. References: Van Der Werff 1977-1978, 180-181; Ramon 2005, Type T-7.2. See also: Guerrero Ayuso 1986, 152, fig. 4.3 (Serra di Vaglio, southern Italy, from a context of 3rd BC). Date: From late 3th to early 2 th century BC; late variants occurred in the first century BC.

\section{$46(3006-3-1-5-1) 706239 \mathrm{E}, 3973549 \mathrm{~N}$}

Maña C2a-Van der Werff 1 amphora, rim. D. 28-32 cm, H. $3.2 \mathrm{~cm}$. Fairly fine and soft light clay (2.5YR 6/8) with frequent small inclusions and few big red particles; irregular and rough fracture of the section. The surface is very eroded. References: Slane 1986, 296, no. 110, pl. 68 (Athens, from a context of the third quarter of the 1st century AD); Riley 1979, 138, no. 56, fig. 70. (Benghazi, early 2nd century BC to the Augustan age); Dore and Keay 1989, 29-30, figs. 143-145 (Sabratha, Libya); Van der Werff 1977-1978, 176-178; Guerrero Ayuso 1986, 163-170, fig. 71 (Na Guardis, Balearic islands, 175-125 BC). Date: Between the first half of the 2nd and the end of the 1 st century $\mathrm{BC}-1$ st century $\mathrm{AD}$, but the occurrences of the second century $\mathrm{BC}$ are predominant; the recent analysis of some Carthaginian contexts has led to the extension of the date of this amphora to the first half of the 1st century AD (MartinKilcher 1999).

47 (4300-28-1-25-4) 707205E, 3974053N

Tripolitanian amphora, rim. D. $17 \mathrm{~cm}, \mathrm{H} .4 .3 \mathrm{~cm}$. Quite fine and hard 'sandwich' clay (the core is red-5YR 7/8, the surfaces are black) with occasional small and white inclusions, rare voids of medium and large size; sharp and rough fracture of the section. Tripolitanian fabric. References: The rim might be associated with one of the earlier African amphorae of Graeco-Roman type, which represent the typological link between the Van der Werff Type 3 and the Tripolitanian amphorae. It can be classified as a Dressel 26 -Bonifay 13: Bonifay 2004, 101, fig. 52. Some good comparisons with our rim are Empereur and Hesnard 1987, pl 9, 35-36, figs. 41-42 (2nd century BC?); Bats, Andreau and Barbet 2006, 216, fig. 7, no. 11 (Olbia, Provence, 40-30 BC to $10 \mathrm{AD}$ ); Panella 2001, fig. 25, no. 179 (Leptis Magna, 
Augustan period); Panella 1977, 144, pl. LXIX, no. 43 (from a context of the end of the 1st century BC). Date: Mid 2nd to the end of the 1st century BC-early 1st century AD.

48 (8181-28-1-35-1) 709372E, 3971022N

Tripolitanian 2-Keay 9 amphora, rim. D. $18 \mathrm{~cm}$, H. $5.2 \mathrm{~cm}$. Quite fine and hard reddish yellow clay (5YR 7/7 with pale surface), with common white grains (quartz?) of small and medium size, voids of medium and large size; sharp and smooth fracture of the section. Tripolitanian fabric. References: Peacock, Bejaoui and Belazreg 1989, 191, figs. 13, nos. 24, 26 (Carthage); Riley 1979, 166-167, no. D 161, fig. 77. (Benghazi, 1st century AD); Keay 1984, 129-131, fig. 20.5: Slane 1986, 295-296, no. 109, pl. 68 (Athens, 'Tripolitanian 1' from a context of the third quarter of the 1st century AD);. Date: This amphora occurred from the end of the 1st century AD until $250 \mathrm{AD}$; local occurrence is attested in the 4th century AD.

49 (1096-6-1-95-1) 707350E, 3974194N

'Africana 2A' amphora: rim, neck and handle. Tunisian fabric. D. $14 \mathrm{~cm}, \mathrm{H} .8 .3 \mathrm{~cm}$. Fine and hard reddish-yellow clay (5YR 6/6), with frequent white grains (quartz?) of small and medium size, voids of medium and large size; sharp and smooth fracture of the section. The surface, pale in colour, is completely eroded. References: The rim may be attributed to one of the most common African amphorae in the Mid-Roman period; a recent revision of the classification of its types and variants is in Bonifay 2004, 107-122. Our rim may be close to the type 2A; Bonifay 2004, 111, fig. 58, no. 8. See also Ostia III, nos. 583-585. Date: Second half of the 2nd to within the 4th century AD.

50 (8186-28-1-45-2) 709401E, 3970727N

'Africana 2A grande' amphora (?), rim. D. not measurable, H. $3.5 \mathrm{~cm}$. Quite fine and hard light red clay (2.5YR 6/8 with pale surface), with common white grains (quartz?) of small and medium size, voids of medium and large size; sharp and smooth fracture of the section. Tunisian fabric (?). References: The rim is very similar to a variant of the 'Africana 2A grande' amphora, which was attested in African contexts of mid to second half of the 3rd century AD: Bonifay 2004, 111, fig. 58, 7. See also Maioli and Stoppioni 1989, 573, fig. 1 (from Classe, Ravenna, Italy). Date: 3rd century AD.

\section{1 (1072-1-1-75-1) 707194E, 3973253N}

Late Rhodian amphora (=Camulodunum 184/ Agora F 94), rim. D. 14 cm, H. $2.2 \mathrm{~cm}$. Fine and hard light red clay (2.5YR 5-6/6), with scarce white inclusions, rare mica; sharp and rough fracture of the section. References: Desbat and Picon 1986, fig. 4, 1 (Lyon, France, late 1st century BC to 1st century AD); Hesnard 1986, 73, fig. 1.2 (Camulodunum, first half of 1 st century AD). Date: Late 1 st century BC to mid 2 nd century AD.

52 (4299-29-1-25-1) 707172E, 3974005N

Late Rhodian type (=Camulodunum 184/ Agora F 94) or Dressel 2-4 (Koan type/Agora F 93) amphora, rim. D. $7 \mathrm{~cm}, \mathrm{H} .4 \mathrm{~cm}$. Fine and hard reddish-yellow clay (7.5YR 6/6), with occasional small red-brown particles; sharp and smooth fracture of the section. References: The fabric of this rim recalls the Rhodian fabric 1, which is characterised by prominent red grains of serpentine: Peacock and Williams 1986, 102104 (class 9); see also an overview of the Rhodian fabrics: Whitbread 1995, 58-59. 
Nevertheless, the morphology of the rim may recall some eastern Dressel 2-4 amphorae (Koan type?), which were identified in Augustan contexts in France: Desbat and Martin-Kilcher 1989, 341, pl. 2, 8 (Saint-Romain-en Gal); Desbat 1987, fig. 3.2. (Lyon). Date: Late 1 st century BC to mid 2nd century AD.

53 (4314-20-1-35-1) 707262E, 3974031N

Late Rhodian type (Camulodunum 184/Agora F 94 ?) amphora, rim. D. 12 cm, H. 2,7 $\mathrm{cm}$. Quite fine and hard reddish yellow clay (7.5YR 6/6), with black core; frequent red-brown and white particles of small and medium size; sharp and rough fracture of the section. The surface is eroded. Rhodian fabric. References: Robinson 1959, F 94, pl. 3. Our rim is very similar to a Rhodian type amphora from Lyon, which was produced in some eastern ateliers: Desbat and Picon 1986, 640, fig. 4.2 (this find context was dated to the late 1 st century BC-1st century AD). See also a similar amphora from an early Roman context at Carthage (40-20 BC-70 AD): MartinKilcher 2005, fig. 7.5. A Rhodian amphora from Chania (Crete), which has been dated from the 1 st century $\mathrm{BC}$ to the 1 st century $\mathrm{AD}$, is very similar to our fragment but its fabric appears to differ from ours: Andreadaki Vlasaki, Hahn and Hallager 1997, 206, no. 77-P 0726, pl. 65. Date: Late 1st century BC to mid 2nd century AD.

54 (4314-28-1-35-1) 707239E, 3974025N

Late Rhodian type (Camulodunum 184/Agora F 94 ?) amphora, rim. D. 12 cm, H. 5 $\mathrm{cm}$. Quite fine and hard reddish yellow clay (7.5YR 6/6), with black core; frequent red-brown and white particles of small and medium size; sharp and rough fracture of the section. The surface is eroded. References: A similar Rhodian amphora occurred in the Antikythera shipwreck: Grace 1965, fig. 1 (in the middle of left side). Date: Late 1st century BC to mid 2nd century AD.

\section{5 (3002-19-1-25-1) 706356E, 3973318N}

Dressel 2-4 amphora (type Koan/Agora F 93), rim. D. $16 \mathrm{~cm}, \mathrm{H} .2 .5 \mathrm{~cm}$. Rough and hard reddish yellow clay (5YR 7/8), with occasional small white and, grey inclusions, rare mica; sharp and rough fracture of the section. Koan fabric?. References: The shape recalls some Dressel 2-4 amphorae: Desbat 1987, fig. 3.1 (“(Lyon, France, local fabric, from a context of the Augustan period)); Desbat andMartin-Kilcher 1989, 341, pl. 2, 6 (Lyon, France, Koan fabric, from a context of Augustan period); Bailey 1993 235, no. 105 (Sparta, Roman Stoa, from a pottery group dated to the 1st century AD); Ostia II, 136, no. 32 (Vindonissa, second quarter to the end of the 1st century AD). A Koan amphora was attested in the cargo of the Antikythera shipwreck: Grace 1965, fig. 1, (in the middle of right side). Date: 1st century BC to 1st century AD.

\section{6 (1086-6-1-75-3) 707176E, 3973770N}

Dressel 2-4 amphora (fabric not identified, perhaps Aegean), long bifid handle. H. $11,7 \mathrm{~cm}$. Quite fine and hard reddish yellow clay (7.5YR 6/6), with a few white and, less commonly, black inclusions of small and medium size, rare mica; sharp and smooth fracture of the section. The surface is fairly eroded. References: The Roman amphorae with bifid handles are discussed in Panella and Fano 1977 (a good comparison for our fragment is group 3 and fabric B; 147, 150-151). See also for a general overview of the variety of fabrics of the Dressel 2-4 amphorae Bruno 2005, 375, 377, 381. 384. Date:Late first century BC to mid 2nd century AD.

\section{7 (1107-5-1-65-1) 707278E, 3974222N}


Mau XXXVIII amphora (?), base. D. $4.7 \mathrm{~cm}$, H. $5 \mathrm{~cm}$. Fine and hard red clay (2.5YR $5 / 8$ ), with frequent small and white inclusions, rare mica; sharp and rough fracture of the section. References: See for an overview of this amphora: Panella 1986, 621-622, fig. 18; Bruno 2005, 385, pl. 6,63. Date: Late 1st century BC to the 2nd-3rd centuries AD.

\section{8 (4018-5-1-55-1) 706686E, 3972808N}

Shoulder and handle of an amphora close to Kapitän II/Agora K 113 type. D. not measurable, H. $7.5 \mathrm{~cm}$. Fine and hard red clay (2.5YR 5/8), with occasional small and white inclusions; sharp and smooth fracture of the section. References: For the Kapitän II/Agora K 113 type see Robinson 1959, 89, K 113, pl. 15; Panella 1986, 617-619, fig. 10-11; Peacock and Williams 1986, 193; Empereur and Picon 1989, 233; Bruno 2005, 388. Date: The Kapitän I-II amphorae start in the late 1st to 2nd century AD, but seem to continue into the $3 \mathrm{rd}$ and 4th centuries AD.

\section{9 (8173-27-1-25-1) 706524E, 3973201N}

Cretan 1 amphora (ARC1/Agora G 197), rim. D. $11 \mathrm{~cm}$, H. $3.2 \mathrm{~cm}$. Quite fine and soft reddish-yellow clay (5 YR 7/6; the surface is yellow-10YR 8/4), with a few white inclusions of small and medium size, sharp and smooth fracture of the section. References: This rim is attributable to a Cretan amphora (I. Romeo pers. comm.) and it may be ascribed to the variant IA of Marangou-Lerat's classification: MarangouLerat 1995, 68-70, pl. IV, A 29. It is also similar to an amphora from Ostia, which was dated through the third quarter of the 1st century and 150 AD: Ostia III, 207, 476-477, no. 373, pl. XLVII. Date: The type ARC 1 dates from the early 1 st to the mid-4th century AD; variant A may occur from the 1st to the beginning of the 3rd centuries AD.

$60(4304-28-1-45-3)$ 707132E, 3973952N

Cretan 1 amphora (ARC1/Agora G 197), rim. D. $13 \mathrm{~cm}$, H. $3.7 \mathrm{~cm}$. Fairly fine and soft reddish yellow clay (5YR 7/6; the surface is yellow-10YR 8/4), with occasional white inclusions of small and medium size, sharp and smooth fracture of the section. The surface, which may have had a slip, is eroded. References: This rim belongs to a Cretan amphora (I. Romeo pers.comm.) and it might be attributed to the type ARC1/Agora G 197: Marangou-Lerat 1995, 68-70, pl. III, no A23, A 26 (Knossos, from contexts dating from 160-180 AD and from the first half of the 3th century $\mathrm{AD}$ ). The type is very frequent in Crete: Hayes 1983, 143, fig. 20, no. A1, A12, A 17 (Knossos, Crete). Date: see 59.

\section{1 (4298-29-1-35-1) 707180E, 3973958N}

Cretan 1 amphora (ARC1), rim. D. $10 \mathrm{~cm}$, H. $6.8 \mathrm{~cm}$. Quite fine and soft reddish yellow clay (5YR 6/8), with a few small white inclusions, sharp and dusty fracture of the section. The surface, which may have been covered with a thin pale slip, is badly preserved. References: This rim is consistent with a Cretan amphora (I. Romeo pers.comm.) and it may be identified as the variant D of type 1 of Marangou-Lerat's classification: Marangou-Lerat 1995, 74, pl. IX, fig. 44, no A 59 (=MRC2). Date: The type ARC1 dates from the early 1 st to the mid-4th century AD; variant $\mathrm{D}$ seems to occur in the last two centuries of this chronological range.

$62(4303-28-1-15-2) 707119 \mathrm{E}, 3974041 \mathrm{~N}$

Cretan 2 amphora (ARC2), rim. D. $11 \mathrm{~cm}$, H. $4.6 \mathrm{~cm}$. Quite fine and hard red clay 
(10R 5/6), with few and small white inclusions, sharp and smooth fracture of the section. The surface, which might have had a slip, is eroded. References: This rim may be attributed to the Cretan ARC2 type : Marangou-Lerat 2004, 1038, no. 16, pl. III (near Alexandria, from an underwater discovery). See also a close comparison with amphorae from a Neronian context at Knossos: Sackett 1992, 180, fig. 7.3 214, pl. 159 , N.47. The type is discussed in Marangou-Lerat 1995, 77-82 (see particularly the figure in pl. XIVa). Date: Early 1st to early 3rd century AD.

63 (4307-20-1-15-11) 707201E, 3973912N

Cretan 2 or 4 amphora (ACR2-ACR4), rim. D. $12 \mathrm{~cm}, \mathrm{H} .2 .3 \mathrm{~cm}$. Quite fine and hard light red clay (2.5YR 6/8), with occasional small white inclusions, sharp and rough fracture of the section. The surface is badly preserved. References: The lack of the distinctive handle makes a precise attribution to the types ARC2 or ARC4 impossible. Marangou-Lerat 1995, 110-111, pl. XIII, fig. 55, A 87 (type ARC2a), MarangouLerat 1995, 117, pl. XIX, fig. 70, A 129-130 (type ARC4a). Date: Early 1st to early 3rd century AD. (type ARC2); early 1st to the first half of the 3rd century AD (type ARC4)

64 (4300-29-1-25-4) 707164E, 3974049N

Cretan amphora (type MRC1-3?), rim. D. $11 \mathrm{~cm}$, H. $6.8 \mathrm{~cm}$. Quite fine and hard light red clay (2.5YR 5/6 with grey core) with few, white and red inclusions of small and medium size, sharp and smooth fracture of the section. The surface is eroded. References: The closest comparisons for this rim are with later variants of Cretan amphorae, which were produced in the island in the 3rd-5th centuries AD: Hayes 1983, 141, fig. 20, no 8-9 (Knossos); Portale and Romeo 2000, 419, type MRC1, fig. 1 (Gortyn, second half of the 2nd to the 4th century AD); Portale and Romeo 2001, 276-277, type MRC1, pl. XLII, c (Gortyn, attestations in contexts from the second half of the 3th-early 4th to mid 5th century AD) and 277, type MRC3, pl. XLIII, b (Gortyn, attestations in contexts from the 3rd to mid 4th century AD); Sackett 1992, S1-28-29 (Knossos); Coldstream, Eiring and Forster 2001, 161, fig. 4.12 f (Knossos, late 2 nd to early 3rd century $A D$ ). See also a amphora from Khania (Crete), which was identified as type ARC1b and was dated to the 1st century AD: Raab 2001, 68, no. 36, fig. 12. Date: Late 2nd-3rd to mid-5th centuries AD.

65 (3174-6-1-75-4) 705495E, 3974426N

Cretan amphora (type MRC2?), rim. D. $8 \mathrm{~cm}$, H. $5.4 \mathrm{~cm}$. Fine and soft reddish-yellow clay (5YR 7/8; the surface is yellow 10 YR 8-4) with rare small inclusions; sharp and smooth fracture of the section. References: The rim might be attributed to the type MRC2, a late variant of the type AC1d which occurred in Crete in the second half of the 3rd to the 5th centuries AD: Portale and Romeo 2000, 419, fig. 1 (Gortyn); Portale and Romeo 2001, 276, pl. XLII, d (Gortyn, variant MRC2A). This type also occurred at Eleutherna, where it was mainly attested in the 4th century AD: Yangaki 2005, 185-188, fig. 47.c (variant MRC2a). With respect to the late production of Cretan amphorae, see also Yangaki 2004-2005.

\section{$66(3623-42-1-15-2) 708429 \mathrm{E}, 3970273 \mathrm{~N}$}

Keay 35 amphora, rim. D. $12 \mathrm{~cm}$, H. $2.4 \mathrm{~cm}$. Quite fine and hard reddish yellow clay (5YR 7/8 with a pale-white surface), with frequent small, white grains (quartz?); sharp and smooth fracture of the section. Tunisian fabric. References: The rim might be attributed to the Keay 35 amphora: Keay 1984, 233-240, fig. 99; Bonifay 2004, 
134-135. Similar comparanda are common: Bonifay 2004, 133, fig. 72a, 3 (Tomis, 5th century AD); Riley 1979, 226-227, no. 363, fig. 92 (Benghazi, 6th century AD); Biondani 2008, 394, pl. L (Verona, Capitolium area). Some amphoras of the late 6th century AD which appear to have rims similar to ours frequently occur in Crete, mainly at Gortyn: Di Vita 1997, 375, pl. CXLII, c (second half-end of the 6th century AD); Rendini 2004, 984, no. 7, fig. 8 (second half of the 6th century AD). Date: 5th6th centuries AD.

\section{7 (8308-2-1-35-1) 709402E, 3970649N}

Keay 34 amphora, rim. D. $14 \mathrm{~cm}$, H. $4.7 \mathrm{~cm}$. Quite fine and hard light red clay (2.5YR 6/8), with frequent white and small rounded grains (possibly aeolian quartz); irregular and rough fracture of the section. The surface, pale in colour, is completely eroded. Tunisian fabric. References: Bonifay, 2004, 143, fig. 77, 4. See also an amphora from Marseilles, which was dated to the 6th century AD: Bonifay, Carre, and Rigoir 1998, 116, fig. 85, n. 39. Date: 6th-7th centuries AD.

68 (4047-14-1-5-4) 706505E, 3972463N

Keay 61A amphora, rim. D. $14 \mathrm{~cm}, H .5 .3 \mathrm{~cm}$. Quite fine and hard light red clay (2.5YR 6/8), with frequent and rounded white grains (possibly aeolian quartz) of small and medium size; sharp and rough fracture of the section. The surface is pale. Tunisian fabric. References: Keay 1984, 303-305, fig. 132, 1; Bonifay 2004, 140-141. Date: Bonifay dates this variant to mid-second half of the 7 th century AD.

69 (3436-16-1-75-1) 707909E, 3971983N

Keay 62A amphora, rim. D. $14 \mathrm{~cm}, \mathrm{H} .7 .5 \mathrm{~cm}$. Quite fine and hard light red clay (2.5YR 6/8), with frequent and rounded white grains (possibly aeolian quartz) of small and medium size; sharp and rough fracture of the section. The surface is pale. Tunisian fabric. References: This rim belongs to one of the most common late African amphorae in the Mediterranean area. It belongs to the variant A: Keay 1984, 309-350, particularly fig. 135-143; Bonifay 2004, 137-140. Date: Bonifay dates the variant A to the first half of the 6th century AD

\section{0 (12083-58-1-5-1) 709581E, 3970282N}

Late African amphora, base. D. $4 \mathrm{~cm}, \mathrm{H} .12 \mathrm{~cm}$. Quite fine and hard light red clay (2.5YR 6/8), with frequent and rounded white grains (possibly aeolian quartz) of small and medium size; sharp and smooth fracture of the section. The surface is pale. Tunisian fabric. References: The base could be related to different Late Roman African amphorae, but particularly to the types Keay 61 or 62 ; nevertheless, it is difficult to identify which type it comes from. Good comparisons are with Peacock, Bejaoui and Belazreg 1989, fig. 7, 1 (Henchir ech Chekaf, Tunisia, type Keay 62); Keay 1984, 308, fig. 134, 7-12, 339-341, fig. 157-159 (type Keay 61A); Bonifay 2004, 138, fig. 74, 12 (shipwreck La Palud, type Keay 62A), 139, fig. 75, 9 (Marseilles, type 61A). Date: 6th - 7th centuries AD.

71 (4298-17-1-15-1) 707210E, 3973943N

African amphora (?), rim. D. $18 \mathrm{~cm}$, H. $4.5 \mathrm{~cm}$. Quite fine and soft light reddish yellow clay (5YR 6/8) with few white inclusions of small and medium size; sharp and smooth fracture of the section. Dusty surface. References: The rim might hesitantly be compared with the Keay 61 type: Keay 1984, 252-255. See a good comparison in Járrega Dominguez 2005, 152, fig. 1.11 (Barcelona, from a context of the second half 
of the 6th to the 7th century AD)"Date: The type is dated from the late 5th to 6th century AD.

72 (3678-19-1-5-1) 708318E, 3970267N

Rim and handle of an unidentified amphora; the rim is quite thin and sharply everted. D. $10 \mathrm{~cm} \mathrm{H.} 5.7 \mathrm{~cm}$. Rough and hard brown clay (7.5YR 5/4), with frequent white, black and grey inclusions (quartz, calcite?) of small and medium size; irregular and rough fracture of the section. References: The rim might hesitantly be attributed to the latest variant of the LR 1 amphora; however the exact variant is very difficult to identify. See for close comparisons: Bezeczky and Scherrer 2005, 206, pl. 3, 24 (Ephesus, Tetragonos-Agora); Riley 1979, 216, no. D346 (Benghazi, small variant of 6th and 7th centuries AD); Pieri 2005, 47, fig. 24, n. 5 (Toulon, variant B of mid-6th century $\mathrm{AD})$ ). The shape of this rim also recalls other late eastern variants which were the prototypes of the small globular amphorae which occurred in the 8th-9th centuries AD: Saguì 1998, 315-317, fig. 8, 5 (a Castrum Perti amphora from a 7th century context at Rome); Portale and Romeo 2001, 357, pl. LXXIII.a (Gortyn). See also an African globular amphora, which recalls the latest variant of the LR2 amphora and corresponds to the LR13 amphora: Bonifay 2004, 153, fig. 83, no. 4; Demesticha 2005 (for the LR13 amphora). Date: 6th-8th centuries AD.

\section{3 (3437-28-1-95-2) 707883E, 3972025N}

LR 1/Agora M 333 amphora, handle; there is a deep groove along the thick handle. H. $9,5 \mathrm{~cm}$. Rough and soft light brown clay (10YR 8/4), with very frequent white, black, red and grey inclusions (quartz, calcite?) of small and medium size; irregular and rough fracture of the section. References: For an overview of the LR 1 amphora: Empereur and Picon 1989, 236-243, Williams 2005, Pieri 2005. The handle might belong to variant B1 of the LR 1 amphora: Murialdo 2005, 397, pl. 3. See also Riley 1979, 215, no. 337, pl. 91 (Benghazi) Date: 6th-7th centuries AD.

\section{4 (8188-26-1-45-1) 709358E, 3970657N}

LR 2/Agora M235/272 amphora, rim. D. $11 \mathrm{~cm} \mathrm{H.} 5.7 \mathrm{~cm}$. Rough and hard reddishyellow clay (7.5YR 6/4), with abundant white and grey inclusions (quartz, mica, calcite?) of small, medium and large size; irregular and smooth fracture of the section. References: The rim may be attributed to variant B of the LR 2 amphora: Pieri 2005, 88, fig. 45 (mid-6th century AD)"); Murialdo 2005, 397, pl. 3. See also Riley 1979, 217-219, no. 348-349, pls. 91-92 (Benghazi, Libya); Portale and Romeo 2001, 352354, pl. LXXI, a (Gortyn, early 6th century AD). Date: The LR 2 amphora is dated to the early 4th to the 6th centuries $\mathrm{AD}$; variant $\mathrm{B}$ occurred from middle of the 6th century AD.

75 (3437-28-1-95-2) 707883E, 3972025N

LR2/ Agora M235/272 amphora, wall: deep and wavy grooves on the surface. W. 0.6 $\mathrm{cm} \mathrm{H.} 4.5 \mathrm{~cm}$. Rough and hard reddish-yellow clay (5YR 6/8 to 7.5YR 7/4), with frequent white and grey inclusions (quartz, mica, calcite?) of various size; irregular and smooth fracture of the section. Date: Wavy grooves are very common particularly in the late 6th century AD (Pieri 2005, 88).

$76(4055-17-1-85-1)$ 706319E, 3972851N

LR 5-6/ Agora M 229-230 amphora (?), rim, vertical rim with a deep groove below the top. D. $10 \mathrm{~cm}$, H. $3 \mathrm{~cm}$. Rough and soft reddish yellow clay $(5 \mathrm{YR} 5 / 6)$, with 
frequent white and grey inclusions (quartz, mica, calcite?) of small, medium and large size; irregular and rough fracture of the section. The surface is eroded. References: The rim bears to be similar to some LRA 5-6 rims; nevertheless, the attribution to this form is uncertain; Pieri 2005, 119-121 (type 3), pl. 46, no. 2 (Marseilles, from a context of the end of the 6th century AD); Slane and Sanders 2005, 278, no. 4-19, fig. 11 (Corinth, from a context of mid-third quarter of 7th century AD). Date: Late 6th to the second half of the 7th century AD.

\section{7 (4082-5-1-95-2) 706273E, 3972409N}

Unidentified amphora (variant of LR 5 amphora?), rim; truncated-conical profile of the neck, rim with slight grooves on the outer surface; D. $10 \mathrm{~cm}, \mathrm{H} .4 .2 \mathrm{~cm}$. Very rough and soft reddish-yellow clay (7.5YR 6/4), with very frequent white and grey inclusions (quartz, mica, calcite?) of small and medium size; irregular and rough fracture of the section. References: The rim has parallels with some of the latest variants and derivations of the LR 5 amphora, which were produced in the 7th-8th centuries AD: Zemer 1978, nos. 60-62 (Palestine); Riley 1979, 224, pl. XXXVI, a (Apollonia); Peacock and Williams 1986, 216, no. 63, fig. 136; Villa 1994, 411, pl. 10.8 (unknown provenance); Pieri 2005, 117, fig. 76, type 5.

\section{8 (6067-23-1-55-1) 708515E, 3971294N}

Amphora (LR 7/ amphora?), base: it ends with a tapering spike. D. $2.2 \mathrm{~cm}, \mathrm{H} .4 \mathrm{~cm}$. Rough and hard reddish yellow clay (5YR 5/6 with darker core), with frequent white inclusions of small and medium size; irregular and rough fracture of the section. The surface is eroded. References: The comparisons with the base of the LR 7 amphora are doubtful: Empereur and Picon 1989, 244-245; Arthur 1998, 163, fig. 4, 3; Pieri 2005, 131, fig. 86 (first drawing on the left, top). For a detailed overview of LR 7 amphora: Pieri 2005. Date: The amphora is dated from the late 4th to the 7th-8th centuries AD.

\section{9 (11308-59-1-5-1) 710188E, 3968576N}

Amphora (LR 7 amphora?), handle and part of neck; the curved handle joins a narrow neck. H. $5 \mathrm{~cm}$. Quite fine and hard, dark reddish-brown clay (5YR 4/4), with occasional white inclusions of small and medium size; irregular and rough fracture of the section. The surface is very eroded. References: See references under no. 78. Date: See 78.

\section{0 (1131-3-1-45-1) 707393E, 3973704N}

Amphora, base; flat base with a concave indentation in the middle. W. $0.5 \mathrm{~cm}, \mathrm{H} .1$ $\mathrm{cm}$. Fine and soft reddish yellow clay (7.5YR 7/6), occasional small inclusions; sharp and dusty fracture of the section. References: The flat shape of the base is typical of the Keay 52 amphora, a southern Italian production with a micaceous fabric which occurred around the middle of the 4th to the 7th century AD: Keay 1984,267-268, fig. 114; Bonifay and Villedieu 1989, 33-34, fig. 11, n. 12; Pacetti 1998. Another amphora with flat and concave base is the Castrum Perti form, a production with a sandy light orange or light brown fabric which is dated to the 7th and 8th centuries AD. See Saguì 1998, 315-317, fig. 8.5 (Rome, from a context of the 7th century AD). The fabric and the shape of our base seem to be more similar to those of the latter form. Date: Around the middle of the 4th to the 7th centuries AD or 7th- 8th centuries AD. 
81 (1087-3-1-15-2) 707255E, 3973727N

Unidentified amphora, rim: small everted rim, which joins on to the shoulder directly. D. $11 \mathrm{~cm}$, H. $3 \mathrm{~cm}$. Rough and soft reddish-yellow clay (5YR 6/8), frequent white and grey inclusions (calcite, quartz?) of small and medium size (mainly along the surface); irregular and rough fracture of the section. The surface is badly preserved. References: It might hesitantly be identified as a variant of the LR4 amphora based on their similar fabrics: Pieri 2005, 103, fig. 66, B1 (end of the 5th-first half of the 6th century AD.) and 106-107, fig. 66, B2-3 (second half of the 6th century AD to 7th century AD). Date: 6th-7th centuries AD.

\subsection{COARSE WARE, COOKING VESSELS AND OTHERS}

82 (4072-5-1-65-2) 706560E, 3972452N

Basin, rim. Coarse ware. Everted and strongly rounded rim, curved wall. D. int. 43 $\mathrm{cm}, \mathrm{H} 3 \mathrm{~cm}$. Quite fine and soft reddish-yellow clay (7.5YR 7/4 with grey core), a few small black inclusions, a few mica particles; sharp and smooth fracture of the section. References: The rim might be similar to a basin from Gortyn, which was found in a context dated to the second or third quarter of the 7th century AD: Albertocchi and Perna 2001, 469, pl. CLVIII, no. C IV 3.1-4. Date: Late Roman.

83 (3436-5-1-15-1) 707942E, 3971932N

Basin, rim. Coarse ware. Slightly everted rim, curved wall. D. int $30 \mathrm{~cm}, \mathrm{H} 3.8 \mathrm{~cm}$. Quite fine and hard reddish yellow clay (7.5YR 6/6 with grey core), frequent black and grey inclusions of small and medium size; sharp and smooth fracture of the section. References: The rim is similar to a type which occurred at Gortyn from the 3rd century but mainly during the 6th and the 7th centuries AD: Albertocchi and Perna 2001, pl. CLVI, CII 3.2-1-2. Another good comparison is also attested at Argos, but dating from the Late Hellenistic period to the Augustan age: Abadie-Reynal 2007, 202, no. 331, pl.49. Date: uncertain.

84 (4035-14-1-45-1) 706566E, 3972813N

Basin, rim. Coarse ware. Everted and flat rim, truncated-conical body. D. int $28 \mathrm{~cm}, \mathrm{H}$ $4.4 \mathrm{~cm}$. Quite fine and soft reddish-yellow clay (7.5YR 7/4 with gray core), few small black inclusions, few mica particles; sharp and smooth fracture of the section. References: This rim appears to be common in several Aegean and eastern contexts of Middle and Late Roman date (mainly on Crete). It is very similar to the following basins: Hayes 2001, 442, fig. 5, no. 54 (Knossos, late 6th to 7th century AD) and Hayes 1983, 133, fig. 16, no. 189 (Knossos, Early Roman context); Albertocchi and Perna 2001, 466, pl. CLVI, no. C II 3.1-1; 464, pl. CLII, no. B VII 3.1-1; Martin 1997a, 308, no. 127, pl. LXXIV, 1 (Gortyn, from the end of the 4th to the 7th century AD; Empereur, Marangou and Papadakis 1992, p. 646, fig. 10(eastern Crete); Riley 1979, 343-344, fig. 125, no. 898-899 (Benghazi, Libya), Gasperetti 2003, 151, pl. XCIV , 40 (Iasos, Turkey). Date: Middle and Late Roman.

85 (8186-28-1-45-1) 709402E, 3970727N

Basin, rim. Coarse ware. Everted and flat rim, slightly rounded on the outer surface; curved body. D. int. $33 \mathrm{~cm}, \mathrm{H} 4.1 \mathrm{~cm}$. Quite fine and soft reddish yellow clay (7.5YR 7/6 with grey core), occasional small black inclusions, occasional mica particles; sharp and smooth fracture of the section. References: Very similar to some local basins from Eleutherna (Crete): Vogt, Gouin and Aloupi 2000, 74, fig. 24.4-5. The rim might also be compared with a Gortynian type, which was found in a layer of the 
second-third quarter of the 7th century AD: Albertocchi and Perna 2001, 468, pl. CLVIII, C IV 3.1-2. Date: Late Roman.

\section{6 (8298-14-1-15-2) 709473E, 3970650N}

Basin, rim. Coarse ware. Everted and slightly rounded on the outer surface of the rim, with wide and shallow grooves on the top. D. int $36 \mathrm{~cm}, \mathrm{H} 2.3 \mathrm{~cm}$. Quite fine and soft reddish yellow clay (7.5YR 6/6), very frequent small inclusions (mica?); sharp and smooth fracture of the section. References: The rim is similar to a basin from Knossos of the 7th century AD: Hayes 2001, 449, fig. 8, no. B50. Other late Roman and early Byzantine basins from the Aegean area might be compared with our rim: Albertocchi and Perna 2001, 468, pl. CLXVII, C VII 3.1-4 (Gortyn, second-third quarter of 7th century AD); Rendini 1988a, 238, no. 218, fig. 202 (Gortyn, 6th century AD); Riley 1979, 343, no. 896, fig. 124 (Benghazi, from 1st to 3rd century AD). Some bowls from the Anatolian area might be comparable with this Antikythera type: Lüdorf 2006, 64; Pülz 1987, 16, pl. 11, no. 31 (Miletus, from a mid-Imperial context). Date: Late Roman?

\section{7 (11326-57-1-25-3) 710135E, 3967100N}

Rim. Coarse ware. Everted and rounded on the outer surface, with wide and shallow grooves on the lower surface. D. int. $22 \mathrm{~cm}, \mathrm{H} 2.2 \mathrm{~cm}$. Quite fine and soft reddish yellow clay (5YR 6/6), very few white and grey inclusions (calcite and quartz?) of small and medium size; sharp and smooth fracture of the section. The surface is very eroded. References: The shape of the rim resembles that of a basin from a 1st century AD level at Dydima: Wintermeyer and Bumke 2004, 19, no. 85, type S 7.3, pl. 52. Date: Early Roman?

\section{8 (4210-14-1-25-1) 706686E, 3972331N}

Bowl, rim. Coarse ware. Incurved and rounded on the top of the rim; curved body. D. ext. $20 \mathrm{~cm}, \mathrm{H} 2.7 \mathrm{~cm}$. Very fine and soft reddish yellow clay (7.5YR 7/6), few small black and grey inclusions (calcite and quartz?), frequent voids; sharp and smooth fracture of the section. References: The rim is reminiscent of the morphology of the PRS form 1B-C. See a specimen from a Spartan context of the early 5th century AD: Pickersgill and Roberts 2003, 584, no. 97b, fig. 14. Date: End of the 4th to 5th century AD.

\section{9 (4034-14-1-35-2) 706601E, 3972918N}

Rim. Coarse ware. Vertical and rounded on the top of the rim, which joins the vertical shoulder sharply. D. ext. $24 \mathrm{~cm}, \mathrm{H} 3.6 \mathrm{~cm}$. Quite fine and hard reddish yellow clay (2.5YR 7/6 on the core and 7.5 YR 6/6 on the surface), few white and grey inclusions (quartz?) of medium size, frequent large voids; sharp and smooth fracture of the section. References: The shape cannot be identified with any certainty. The rim could belong to a bowl similar to: Albertocchi and Perna 2001, pl. XCV, XII 1.1-2; 3-2-2. (Gortyn); Abadie-Reynal and Sodini 1992, 47, fig. 20, CC 127 (Thasos, around 600 AD); Eiwanger 1981, 43, pl. 13, II 168-181 (Demetrias, 5th-6th centuries AD). The fragment may also be from a funnel, as some comparisons with items of 3rd century AD date from Corinth might suggest (K. Slane, pers. comm.): see Williamsand Zervos 1983, 16-17, no. 34. Date: 3rd to 5th-6th centuries AD.

$90(4210-29-1-25-1) 706703 \mathrm{E}, 3972327 \mathrm{~N}$

Bowl, rim. Coarse ware. Broad flat and sloping rim, with a deep and narrow groove 
on the top. D. ext. $24 \mathrm{~cm}, \mathrm{H} 1.3 \mathrm{~cm}$. Very fine and hard reddish yellow clay (5YR 6/6 on the core and 5YR 7/6 on the surface), scarce small inclusions, sharp and smooth fracture of the section. References: The form is quite common among fine wares from the Hellenistic to Late Roman period; this rim might be an imitation in coarse ware and the shape is quite common in the coarse ware of Aegean area: Rotroff 2006, 114115, no 291-305, figs. 50-52 (Athens, 350-150 BC); Abadie-Reynal 2007, 205, no. 340 , pl. 51 (Argos, from the Augustan period to the 4th century AD); Albertocchi and Perna 2001, 433, pl. XCIII, no. IX 2.1-2; Martin 1997a, 299-300, no 40, pl. LIX, 10 (Gortyn, Hadrianic age and late 6th - early 7th centuries AD); Pickersgill and Roberts 2003, 585, no. 104, fig. 15 (Sparta, early fifth century AD). Date: Hellenist to Late Roman Period.

\section{1 (12062-57-1-15-1) 709874E, 3970706N}

Jug, rim. Coarse ware. Slightly everted and thin rim, flat on the top; thin and curvilinear neck D. $11 \mathrm{~cm}, \mathrm{H} 2.7 \mathrm{~cm}$. Very fine and hard reddish yellow clay (5YR $7 / 6$ ), occasional small inclusions, sharp and smooth fracture of the section. The surface is eroded. References: The shape is not distinctive and there were no suitable comparisons. The form seems to occur in Athens during the Hellenistic period, with a revival during the Roman period: Rotroff 2006, 77-78, no. 53, fig. 10 (context of the third quarter of the 3rd century $\mathrm{BC}$ ). The majority of the comparisons are Late Roman: Albertocchi and Perna 2001, 514, pl. CXXII, no. C I 2.4-1 (Gortyn, first half of the 7th century AD); Piérart andThalmann 1980, 475, A31, pl. III (Argos, from the end of the 4 th to the beginning of the 5th century AD). Date: Hellenistic to Late Roman.

92 (4047-18-1-15-1) 706548E, 3972465N

Jug, rim. Coarse ware. Rim everted and rounded on the outer face; curvilinear neck with a shallow ridge below the rim. D. $10 \mathrm{~cm}, \mathrm{H} 3.7 \mathrm{~cm}$. Very fine and hard reddish yellow clay (5YR 7/6), scarce white inclusions of large size, sharp and smooth fracture of the section. The surface is smoothed. References: The shape has some general similarities with vessels covering a wide chronological range: Rotroff 2006, 249, no. 45, fig. 9 (Athens, 350-260 BC); Malamidou 2005, 61, no. 1286, fig. 84 (Kepia, north-eastern Greece); Piérart and Thalmann 1980, 475, A26, pl. III (Argos, from the end of the 4th to the beginning of the 5th century AD). Date: From Hellenistic to Late Roman.

\section{3 (3447-14-1-25-1) 708004E, 3971453N}

Jug, rim. Coarse ware. Rim slightly everted and thick on the inner surface. D. $10 \mathrm{~cm}$, H $2.7 \mathrm{~cm}$. Fine and hard reddish yellow clay (7.5YR 6/6), occasional small, white inclusions, sharp and smooth fracture of the section. The surface has been smoothed. References: The rim can be comparable to a Gortinian jug, which may suggest the Late Roman phase: Albertocchi and Perna 2001, 509, pl. CXIX, no. A V 2.1-1. It is also reminiscent of a jug rim from a deposit at Argos dating to the first quarter of the 5th century AD: Ivantchik 2002, 399, no. 168, fig. 28. Date: Late Roman?

\section{4 (3573-19-1-35-2) 706767E, 3971507N}

Casserole, rim and part of a handle and body; flat and sloping rim, internal rim-cavity for supporting a lid, sloping body and vertical handle. D. $15 \mathrm{~cm}, \mathrm{H} 4.2 \mathrm{~cm}$. Cooking ware. Rough and hard strong brown clay (7.5YR 5/4), very frequent white and grey inclusions of small, medium and large size (quartz, calcite?), sharp and rough fracture 
of the section. References: The rim might hesitantly be compared to with the 'corrugated pots' which were one of the best attested cooking ware types in the central and eastern Mediterranean in the Middle Roman period; nevertheless, the fabric is quite different from that of the 'corrugated pots' (Hayes 1983). See Treglia 2005, 300, fig. 1.3-6 (end of the 4th to the first half of 5th century AD). See also the following comparison from Gortyn: Martin 1997b, 358, n. 65, pl. CXXXII, 4 (2nd-3rd century AD); Sirano 2001, 553, pl. CXCVI, A VII 1.4. Date: Middle Roman?

95 (3179-6-1-95-2) 705375E, 3974380N

Cooking pot, rim; rim everted, sloping and rounded on the outer surface. Cooking ware. D. not measurable, $\mathrm{H} 1.7 \mathrm{~cm}$. Very rough and hard light red clay $(2.5 \mathrm{YR} 6 / 8)$, frequent white and grey inclusions of medium and large size, sharp fracture of the section. References: On the basis of comparisons with specimens from Crete, this type seems to occur during the Late Roman period; Yangaki 2005, 46, no. 41, fig. 35.a (Eleutherna). Date: Late Roman

$96(12083-58-1-25-1)$ 709599E, 3970282N

Cooking pot, rim; flat and sloping rim, with a sharp junction with the protruding shoulder. Cooking ware. D. $24 \mathrm{~cm}, \mathrm{H} 2.2 \mathrm{~cm}$. Rough and soft reddish yellow clay (7.5YR 7/4), very frequent white and grey inclusions of small, medium and large size (quartz, calcite?), sharp and rough fracture of the section. References: This type is common on Aegean sites during the Late Roman period: Hayes 2001, 440, fig. 5, no. 41 (Knossos, 525-550 AD); Eiwanger 1981, 44-45, pls. 15 and 19, no. II 225 and 303 (Demetrias, 5th-early 6th centuries AD); Pickersgill and Roberts 2003, 586, no. 125ac, fig. 17 (Sparta, early 5th century AD). Date: Late Roman.

\section{7 (12048-21-1-65-1) 709421E, 3970419N}

Cooking pot, rim and handle. The type is very similar to 96: flat and sloping rim, vertical handle with curvilinear profile and oval section. Cooking ware. D. $20 \mathrm{~cm}, \mathrm{H}$ $2.2 \mathrm{~cm}$. Rough and over-fired dark brown clay (5YR 4/1), very frequent white and grey inclusions of small, medium and large size (quartz, calcite?), sharp and rough fracture of the section. References: There are several close comparisons for this type in Greece (mainly Crete) from the 4th-early 5th to the 7th century AD: Hayes 2001, 440, fig. 5, no. 41 (Knossos, 525-550 AD); Hayes 1983, 126, no. 92, fig. 8 (Knossos, 4th -early 5th century AD); Vogt, Gouin and Aloupi 2000, 79, fig. 31.2 (Eleutherna, 6th -7th centuries AD); Pickersgill and Roberts 2003, 586, no. 126, fig. 17 (Sparta, early 5th century AD). Ivantchik 2002, 402, no. 178, fig. 30 (Argos, first quarter of the 5th century AD). Date: Late Roman.

\section{8 (3481-19-1-15-1) 708047E, 3972165N}

Cooking pot, rim; slightly everted rim, hollowed, rounded on exterior. Cooking ware. D. $24 \mathrm{~cm}, \mathrm{H} 2.4 \mathrm{~cm}$. Rough and soft dark to reddish brown clay $(7.5 \mathrm{YR} 5 / 1$ in the core and 7.5YR 5/4 on the surface), very frequent white and grey inclusions of small, medium and large size (quartz, calcite?), sharp and rough fracture of the section. References: The rim recalls some similar examples from Sparta and Crete, which occurred mainly in the Late Roman period: Martin 1997b, 352-353, n. 23, pl. CXXV, 1 (Gortyn, 2th-3th centuries AD); Rendini 1988b, 260, n. 266, fig. 211 (Gortyn, 6th7th centuries AD); Sirano 2001, 544 pl. CXCI, no. B X 2.1-1 (Gortyn, from contexts of the late 7th to 8th-early 9th centuries AD); Micozzi 2004, 453, no.239, fig. 12 (Gortyn, 5th-7th centuries AD); Coldstream, Eiring and Forster 2001, 158, fig. $4.11 \mathrm{f}$ 
(Knossos, late 5th century AD); Pickersgill and Roberts 2003, 585, no. 122, fig. 17 (Sparta, early 5th century AD). Date: Late Roman.

99 (4004-5-1-45-9) 706577E, 3972750N

Cooking pot, rim; protruding and rounded rim, with a sharp groove on the top. Cooking ware. D. $21 \mathrm{~cm}, \mathrm{H} 2 \mathrm{~cm}$. Rough and soft light red clay (2.5YR 6/8), very frequent white and grey inclusions of small, medium and large size (quartz, calcite?), sharp and rough fracture of the section. References: The type is common in Late Roman Cretan and western Anatolian contexts: Sirano 2001, 541, pl. CLXXXIX, no. B II 3.1-4 (Gortyn, 6th century AD). Lüdorf 2006, 50 (Kochtopftypus VI-1), pl. 12 (western Anatolia, 4th to 6th century AD). Date: Late Roman.

100 (4005-18-1-65-1) 706684E, 3972681N

Casserole, rim; everted and protuding on interior rim, with a triangular section. Cooking ware. D. int. $20 \mathrm{~cm}$, H. $2.2 \mathrm{~cm}$. Rough and hard reddish yellow clay (7.5YR $6 / 6$ ), frequent white and grey inclusions of small, medium and large size (quartz, calcite?), sharp and rough fracture of the section. References: The rim recalls a vessel from Knossos, which was dated late 6th to 7th century AD: Hayes 2001, 442, fig. 5, no. 55. See also another vessel from Corinth, dated from the end of the 6th to the third quarter of the 7th century AD: Slane and Sanders 2005, 272, no. 3-32, fig. 8, 279, no. 4-28, fig. 12. Date: 6th-7th centuries AD.

101 (12300-58-1-55-1) 710078E, 3969585N

Casserole, rim and part of body; the rim is similar to the previous one, but the shoulder is more protruding. D. int $20 \mathrm{~cm}, \mathrm{H} 2.2 \mathrm{~cm}$. Rough and hard reddish yellow clay (5YR 6/6), frequent white and grey inclusions of small, medium and large size (quartz, calcite?), frequent voids; sharp and rough fracture of the section. References: see comparisons for 100. Date: 6th-7th centuries AD. 


\section{REFERENCES}

Abadie-Reynal, C. and Sodini, J.P. 1992. La céramique paléochrétienne de Thasos. Aliki, Delkos, fouilles anciennes (Etudes thasiennes, 13; Paris).

Abadie-Reynal, C. 1989. 'Céramique et commerce dans le bassin égéen du IVe au VIIe siècle, in Hommes et richesses dans l'empire byzantin, 1. IVe - VIIe siècle (Paris), 143-159

Abadie-Reynal, C. 2007. La céramique romaine d'Argos (fin du IIe siècle avant J.-C. fin du IVe siècle après J.-C.) (Etudes péloponnésiennes, 13; Athènes).

Albertocchi, M. 2004. 'Vasellame da mensa in ceramica comune in epoca tardoantica a ', in Creta romana e protobizantina. Atti del Congresso internazionale, Iraklion 2000 (Padova), 989-999.

Albertocchi, M. and Perna, R. 2001. 'Ceramica comune: vasi da mensa e da dispensa', in Di Vita (ed), 411-536.

Andreadaki Vlasaki, M., Hahn, M. and Hallager, E. 1997. The Greek-Swedish Excavations at the Agia Aikaterini Square, Kastelli, Khania, 1970 - 1987 (Skrifter utgivna av Svenska institutet i Athen. $4^{\circ}, 47,1$; Stockholm).

Arthur, P. 1998. 'Eastern Mediterranean amphorae between 500 and 700: a view from Italy', in Saguì, L. (ed.), Ceramica in Italia VI-VII secolo. Atti del convegno in onore di John W. Hayes (Biblioteca di Archeologia medievale, 14: Roma), 157-184.

Aupert, P. 1980. 'Objets de la vie quotidienne à Argos en 585 ap. J.C.', in Etudes argiennes (BCH supp. vol. 6; Paris), 395-457.

Bailey, D.M. 1988. A Catalogue of the Lamps in the British Museum, iii. Roman Provincial Lamps (London).

Bailey, D.M 1993. 'Excavations at Sparta. The Roman Stoa, 1988-91. Preliminary report, 1, b. Hellenistic and Roman pottery', BSA, 88, 221-249.

Bats, M., Andreau, J. and Barbet, A. 2006. Olbia de Provence (Hyères, Var) à l'époque romaine (Ier s. av. J.-C. - VIIe s. ap. J.-C.) (Etudes massaliètes, Aix-enProvence).

Bernal Casasola, D. 2000. 'Las ánforas béticas en los confines del imperio. Primera aproximación a las exportaciones a la pars Orientalis, in Ex Baetica amphorae. Conservas, aceite y vino de la Bética en el imperio romano. Congreso internacional, Ecija y Sevilla 1998. Actas (Ecija), 935-988.

Bevan, A., Conolly, J. and Tsaravopoulos, A. 2008. 'The Fragile Communities of Antikythera', Archaeology International 10: 32-36.

Bevan, A. and Conolly, J. 2009 'Modelling Spatial Heterogeneity and Nonstationarity in Artifact-Rich Landscapes', Journal of Archaeological Science 36.4: 956-964. 
Bezeczky, T. 2004. 'Early Roman food import in Ephesus. Amphorae from the Tetragonos Agora' in Eiring, J. and Lund, J. (eds), Transport Amphorae and Trade in the Eastern Mediterranean. Acts of the International Colloquium at the Danish Institute at Athens, 2002 (Århus), 85-97.

Bezeczky, T. 2006. 'Consumer behaviour in Ephesus in the first century B.C.', in Malfitana, D., Poblome, J. and Lund, J. (eds), Old Pottery in a New Century. Innovating Perspectives on Roman Pottery Studies. Atti del Convegno internazionale di studi, Catania, 2004 (Catania), 287-308.

Bezeczky, T. and Scherrer, P. 2005. 'Late Roman amphorae from the TetragonosAgora in Ephesus. Appendix 1. Notes about the stratigraphical and architectural context of selected amphora-findings from the Tetragonos agora', in Krinzinger, F. (ed.), Spätantike und Mittelalterliche Keramik aus Ephesus (Österreichische Akademie der Wissenschaften. Philosophisch-Historische Klasse. Denkschriften, 332; Wien), 203-229.

Biondani, F. 2008. 'Le anfore africane', in Cavalieri Manasse, G. (ed.), L'area del Capitolium di Verona. Ricerche storiche e archeologiche (Verona), 387-404.

Bonifay, M. 2004. Etudes sur la céramique romaine tardive d'Afrique (BAR IS, 1301; Oxford).

Bonifay, M., Carre, M.B. and Rigoir, Y. 1998. Fouilles à Marseille. Les mobiliers, Ier - VIIe siècles ap. J.C. (Etudes massaliètes, 5; Paris).

Bonifay, M. and Garnier, N. 2007. 'Que transportaient donc les amphores africaines? Annexe: Analyse du contenu d'amphores africaines, in Papi, E. (ed.), Supplying Rome and the Empire. The Proceedings of an international Seminar, Siena-Certosa di Pontignano 2004 (JRA supp. 69; Portsmouth), 8-31.

Bonifay, M. and Villedieu, F. 1989. 'Importations d'amphores orientales en Gaule, Ve - VIIe siècle,' in Recherches sur la céramique byzantine. Actes du colloque organisé par l'Ecole française d'Athènes et l'Université de Strasbourg II, Athènes 1987 (Athènes), 17-46.

Bruno, B. 1995. Aspetti di storia economica della Cisalpina romana. Le anfore di tipo Lamboglia 2 rinvenute in Lombardia. (Studi e ricerche sulla Gallia Cisalpina, 7: Roma)

Bruno, B. 2005. 'Le anfore da trasporto', in Gandolfi, D. (ed.), La ceramica e $i$ materiali di età romana. Classi, produzioni, commerci e consumi (Bordighera), 353394

Cipriano, M.T. and Carre, M.B. 1989. 'Production et typologie des amphores sur la côte adriatique de l'Italie', in Amphores romaines et histoire économique. Dix ans de recherche. Actes du colloque de Sienne, 1986 (Collection de l'Ecole française de Rome, 114; Rome), 339-358. 
Coldstream, J.N., Eiring, L.J. and Forster, G. 2001. Knossos Pottery Handbook. Greek and Roman (British School at Athens. Studies, 7; London).

Coldstream, J.N. and Huxley, G.L. 1972. Kythera. Excavations and Studies Conducted by the University of Pennsylvania Museum and the British School of Athens (London).

Dello Preite, A. 1997. 'Sigillata "Late Roman C" ("Phocaean Red Slip Ware”)', in Di Vita and Martin (eds), 155-192.

Dello Preite, A. and Martin A. 1997. 'Ceramica bizantina sovraddipinta', in Di Vita and Martin (eds), 201-210.

Desbat, A. 1987. 'Les importations d'amphores vinaires à Lyon et Vienne au début de l'Empire. Rapport préliminaire', in El vi a l'antiguitat. Economia, producció $i$ commerç al Mediterrani occidental. I Colloqui d'arqueologia roman (Monografies badalonines, 9; Badalona), 407-416.

Desbat, A. and Martin-Kilcher, S. 1989. 'Les amphores sur l'axe Rhône-Rhin à l'époque d'Auguste', in Amphores romaines et histoire économique. Dix ans de recherche. Actes du colloque de Sienne, 1986 (Collection de l'Ecole française de Rome, 114; Rome), 339-358.

Desbat, A. and Picon, M. 1986. 'Les importations d'amphores de Mediterranée orientale à Lyon (fin du Ier siècle avant J.-C. et Ier siècle après)', in Empereur, J.-Y. and Garlan, Y. (eds), Recherches sur les amphores grecques (BCH supp. vol. XIII), 637-648.

Di Vita, A. (ed) 2001, , v, iii. Lo scavo del pretorio, 1989 - 1995. I materiali (Monografie della Scuola archeologica di Atene e delle missioni italiane in Oriente, 12; Padova).

Di Vita, A. and Martin, A. (eds) 1997. , ii. Pretorio. Il materiale degli scavi Colini, 1970 - 1977 (Monografie della Scuola archeologica di Atene e delle missioni italiane in Oriente, 7; Padova).

Dore, J. and Keay, N. 1989. Excavations at Sabratha, 1948 - 1951, ii. The Finds, $i$. The Amphorae, Coarse Pottery and Building Materials (Society for Libyan Studies. Monographs, 1; London).

Eiwanger, J. 1981. Demetrias, 4. Keramik und Kleinfunde aus der DamokratiaBasilika in Demetrias (Bonn).

Empereur, J.Y. and Hesnard, A. 1987. 'Les amphores hellénistiques', in Céramiques hellénistiques et romaines, 2. (Annales littéraires de l'Université de Besançon, 331. Centre de recherches d'histoire ancienne, 70; Paris).

Empereur, J.Y., Marangou, A. and Papadakis, N. 1992. 'Recherches sur les amphores crétoises, 3', $B C H, 116$, 633-648. 
Empereur, J.Y. and Picon, M. 1989. Les régions de production d'amphores impériales en Méditerranée orientale', in Amphores romaines et histoire économique. Dix ans de recherche. Actes du colloque de Sienne, 1986 (Collection de l'Ecole française de Rome, 114; Rome), 223-248.

Empereur, J.Y. and Tuna, N. 1989. 'Hiérotélès, potier rhodien de la Pérée', $B C H, 113$, 277-299

Firat, N. 2000. 'So-called Cypriot red slip ware from the habitation area of Perge (Pamphylia)', Rei Cretariae Romanae Fautores Acta, 36, 35-38.

Fontana, F. 1998. 'Le imitazioni della sigillata africana e la ceramica da mensa italiche tardo-antiche', in Saguì, L. (ed.), Ceramica in Italia VI-VII secolo. Atti del convegno in onore di John W. Hayes (Biblioteca di Archeologia medievale, 14: Roma), 157-184.

Freeth, T., Bitsakis, Y., Moussas, X., Seiradakis, J.H., Tselikas, A., Mangou, H., Zafeiropoulou, M., Hadland, R., Cate, D., Ramsay, A., Allen, M., Cawley, A., Hockley, P., Malzbender, T., Gelb, D., Ambrisco, W. and Edmunds, M.G. 2006 Decoding the ancient Greek astronomical calculator known as the Antikythera Mechanism', Nature, 7 119, 587-591.

Gandolfi, D. 2005, 'Sigillata focese ("Late Roman C Ware")', in Gandolfi, D. (ed.), La ceramica e i materiali di età romana. Classi, produzioni, commerci e consumi (Bordighera), 233-250.

Gasperetti, G. 2003. 'Osservazioni preliminari sulla ceramica romana di Iasos di Caria. Materiali dal quartiere a sud del teatro', in Abadie-Reynal, C. (ed.), Les céramiques en Anatolie aux époques hellénistique et romaine, Actes de la Table Ronde d'Istanbul, 1996 (Varia Anatolica 15; Istanbul), 141-163.

Gassner, V. 1997. Das Südtor der Tetragonos-Agora. Keramik und Kleinfunde (Forschungen in , 13, 1, 1; Wien)

Grace, V.R. 1965. 'The commercial amphoras from the Antikythera shipwreck', in Weinberg, G.D., Grace, V.R. and Edwards, G.R. (eds), The Antikythera Shipwreck Reconsidered (Transactions of the American Philosophical Society, 55, 3; Philadelphia), 5-17.

Grace, V.R. 1979. Amphoras and the Ancient Wine Trade (Princeton).

Graeve, V.von, Pfrommer, M. and Pülz, S. 1987. 'Milet 1986. Vorbericht über die Arbeiten des Jahres 1986', Ist. Mitt., 37, 5-75

Guerrero Ayuso, V.M. 1986. 'Una aportación al estudio de las ánforas púnicas Maña C', Archaeonautica, 6, 147-186.

Hayes, J.W. 1972. Late Roman Pottery (London).

Hayes, J.W. 1983. 'The Villa Dionysos excavations, Knossos. The pottery', BSA, 78, 
97-169.

Hayes, J.W. 1992. Excavations at Saraçhane in Istanbul, ii. The pottery. (Princeton)

Hayes, J.W. 2001. 'Early Christian pottery from Knossos. The 1978 - 1981 finds from the Knossos Medical Faculty Site', BSA, 96, 431-454.

Hayes, J.W. 2003. 'Hellenistic and Roman pottery deposits from the Saranda Kolones castle site at Paphos', BSA, 98, 447-516.

Hayes, J.W. 2008. The Athenian Agora, xxxii. Roman pottery, Fine-Ware Imports (Princeton).

Hesnard, A. 1986. 'Imitations et raisonnement archéologique: à propos des amphores de Rhodes et de Cos', in Empereur, J.-Y. and Garlan, Y. (eds), Recherches sur les amphores grecques (BCH supp. vol. XIII; Athènes), 69-79.

Ivantchik, A.I. 2002. 'Un puits de l'époque paléochrétienne sur l'agora d'Argos', $B C H$, $126,331-413$.

Járrega Dominguez, R. 2005. 'Anforas tardorromanas halladas en las recientes excavaciones estratigráficas efectuadas en el subsuelo de la Plaza del Rey en Barcelona', in Ma, J., Esparraguera, G., Buxeda i Garrigos, J. and Cau Ontiveros, M.A. (eds), LRCW, 1. Late Roman Coarse Wares, Cooking Wares and Amphorae in the Mediterranean. Archaeology and Archaeometry (BAR IS 1340; Oxford), 151-163.

Johnston, A., Quercia, A., Bevan, A., Conolly, J. and Tsaravopoulos, A. in preparation 'Pottery from an Intensive Survey of Hellenistic Aegila (Antikythera, Greece)' (provisional title).

Karagiorgou, O. 2001. 'LR 2. A container for the military annona on the Danubian border? ', in Kingsley, S. and Decker, M. (eds), Economy and exchange in the East Mediterranean during late antiquity. Proceedings of a conference at Somerville College, Oxford, 1999 (Oxford), 129-166.

Keay, S.J. 1984. Late Roman Amphorae in the Western Mediterranean. A typology and Economic Study. The Catalan Evidence (BAR IS 196; Oxford).

Kenkel, F. 2007. 'The Cypriot Red Slip Ware and its derivatives from Pednelissos in Pisidia', in Çanak. Late Antique and Medieval Pottery and Tiles in Mediterranean Archaeological Contexts. Proceedings of the First International Symposium on Late Antique, Byzantine, Seljuk, and Ottoman Pottery and Tiles in Archaeological Context, Çanakkale 2005 (Byzas. Veröffentlichungen des Deutschen Archäologischen Instituts Istanbul, 7; İstanbul), 131-145.

Kenrick, P.M. 1985. Excavations at Sidi Khrebish, Benghazi (Berenice), iii, i. The Fine Pottery (Libya antiqua, suppl. 5, 3, 1; Tripoli).

Ladstätter, S. 2005. 'Late Roman C-Ware und lokale spätantike Feinware aus Ephesos', in Krinzinger, F. (ed.), Spätantike und mittelalterliche Keramik aus 
Ephesos (Österreichische Akademie der Wissenschaften. Philosophisch-Historische Klasse. Denkschriften, 332; Wien), 143-201.

Lawall, M.L. 2006. 'Consuming the West in the East. Amphoras of the Western Mediterranean in the Aegean before 86 B.C.', in Malfitana, D., Poblome, J. and Lund, J. (eds), Old Pottery in a New Century. Innovating Perspectives on Roman Pottery Studies. Atti del Convegno Internazionale di Studi, Catania, 2004 (Catania), 265-286.

Lecquercq H. 1928. 'Lampes', in Cabrol, F. and Leclercq, H. (eds), Dictionnaire d'Archéologie Chrétienne et de Liturgie (Paris), .

Lindhagen, A. 2009. 'The transport amphoras Lamboglia 2 and Dressel 6A: a central Dalmatian origin?', JRA, 22, 83-108.

Lippolis, E. 2001. 'Ceramica ad engobbio rosso', in Di Vita, A. (ed), 79-85.

Loffreda, S. 1989. Lucerne bizantine in Terra Santa con iscrizioni in greco (Studium Biblicum Franciscanum. Collectio maior, 35; Jerusalem).

Lüdorf G. 2006. Römische und frühbyzantinischeGebrauchskeramik im westlichen Kleinasien. Typologie und Chronologie (Rahden).

Lund, J. 2000. 'Transport amphorae as evidence of exportation of Italian wine and oil to the eastern Mediterranean in the Hellenistic period', in Lund, J. and Pentz, P. (eds), Between Orient and Occident: Studies in Honour of P.J. Riis (Copenhagen), 77-99.

Lund, J. 2007. 'Transport amphorae as a possible source for the land use and economic history of the Akamas Peninsula, Western Cyprus', in Bonifay, M. and Tréglia, J.C. (eds), LRCW, 2. Late Roman Coarse Wares, Cooking Wares and Amphorae in the Mediterranean. Archaeology and Archaeometry (BAR IS 1662; Oxford), 781-789.

Maioli, M.G. and Stoppioni, M.L. 1989. 'Anfore di produzione romagnola, in Amphores romaines et histoire économique. Dix ans de recherche. Actes du colloque de Sienne, 1986 (Collection de l'Ecole française de Rome, 114; Rome), 570-573.

Malamidou, V. 2005. Roman Pottery in Context. Fine and Coarse Wares from five Sites In North-Eastern Greece (BAR IS 1386; Oxford).

Marangou, A. 2004. 'Alexandrie. Une destination pour le vin crétois', in Livadiotti, M. and Simiakaki, I. (eds), Creta romana e protobizantina. Atti del Congresso internazionale, Iraklion 2000 (Padova), 1029-1038.

Marangou-Lerat, A. 1995. Le vin et les amphores de Crète. De l'époque classique à l'époque impériale (Etudes crétoises, 30; Athènes).

Martin, A. 1997a. 'Ceramica comune: vasi da mensa e da dispensa', in Di Vita and Martin (eds), 291-345. 
Martin, A. 1997b. 'Ceramica comune: vasi da fuoco, in Di Vita and Martin (eds), 346-365.

Martin, A. 1998. 'La sigillata focese (Phocaean Red-Slip/Late Roman C Ware)', in Saguì, L. (ed.), Ceramica in Italia: VI-VII secolo. Atti del convegno in onore di John W. Hayes (Biblioteca di Archeologia medievale, 14: Roma), 109-122.

Martin-Kilcher, G. 1999. 'Karthago 1993. Die Füllung eines frühkaiserzeitlichen Pozzo', In Rakob, F. (ed.), Karthago, 3. Die Deutschen Ausgrabungen in Karthago (Mainz), 404-434.

Martin-Kilcher, S. 2005. 'Carthage. Imported Eastern amphorae in the Roman Colonia Iulia', in Berg Briese, M. and Vaag, L.E. (eds),Trade Relations in the eastern Mediterranean from the Late Hellenistic Period to Late Antiquity. The Ceramic Evidence. Acts from a Ph.D - Seminar for Young Scholars, Sandbjerg Manorhouse, 1998 (Odense), 202-220.

Martis, T., Zoitopoulos, M. and A. Tsaravopoulos 2006 'Antikythera. The Early Hellenistic Cemetery of a Pirate's Town', in S. A. Luca and V. Sirbu (eds.) The Society of the Living - the Community of the Dead (from Neolithic to the Christian Era). Proceedings of the 7th International Colloquium on Funerary Archaeology (Sibiu: Bibliotheca Septemcastrensis), 125-134.

URL:

http://arheologie.ulbsibiu.ro/publicatii/bibliotheca/acta\%20V\%20special\%20number/ volum\%20syposion\%20funerary.pdf

Meyer-Schlichtmann, C. 1988. Die pergamenische Sigillata aus der Stadtgrabung von Pergamon, Mitte 2. Jh. v.Chr. - Mitte 2. Jh. n.Chr (Pergamenische Forschungen, 6; Berlin).

Micozzi, M. 2004. 'Ceramica da fuoco', in Di Vita A. (ed.),'Gortyn, vi. Scavi 19791982 (Monografie della Scuola Archeologica di Atene e delle missioni italiane in Oriente, 14; Padova), .

Murialdo, G. 2005. 'Le anfore tra età tardoantica e proto bizantina (V - VII secolo)', in Gandolfi, D. (ed.), La ceramica e $i$ materiali di età romana. Classi, produzioni, commerci e consumi (Bordighera), 395-406.

Pacetti, F. 1998. 'La questione delle Keay LII nell'ambito della produzione anforica in Italia', in Saguì, L. (ed.), Ceramica in Italia VI-VII secolo. Atti del convegno in onore di John W. Hayes (Biblioteca di Archeologia medievale, 14: Roma), 185-208.

Panella, C. 1977. 'Anfore tripolitane a Pompei', in Annecchino, M. (ed.), L'instrumentum domesticum di Ercolano e Pompei nella prima età imperiale (Roma), 135-149.

Panella, C. 1986. 'Oriente ed Occidente. Considerazioni su alcune anfore egee di età imperiale a Ostia', in Empereur, J.-Y. and Garlan, Y. (eds), Recherches sur les amphores grecques (BCH supp. vol. XIII; Athènes), 609-636. 
Panella, C. 2001. 'Le anfore di età imperiale nel Mediterraneo occidentale', in Geny, E. (ed.), Céramiques héllenistiques et romaines, iii (Publications du Centre CamilleJulien, 28; Paris), 177-275.

Panella, C. and Fano, M. 1977. 'Le anfore con anse bifide conservate a Pompei. Contributo ad una loro classificazione', in Méthodes classiques et méthodes formelles dans l'étude des amphores. Actes du Colloque de Rome, 1974 (Rome), 133-164.

Peacock, D.P.S. 1977. 'Roman amphorae. Typology, fabric and origins', in Méthodes classiques et méthodes formelles dans l'étude des amphores. Actes du Colloque de Rome, 1974 (Rome), 261-273.

Peacock, D.P.S., Bejaoui, F. and Belazreg, N. 1989. 'Roman amphora production in the Sahel region of Tunisia', in Amphores romaines et histoire économique. Dix ans de recherche. Actes du colloque de Sienne, 1986 (Collection de l'Ecole française de Rome, 114; Rome), 179-222.

Peacock, D. P. S. and Williams, D. F. 1986. Amphorae and the Roman Economy (London).

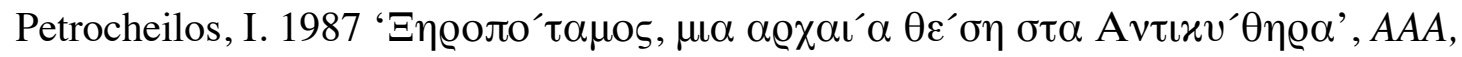
20, 31-42.

Pettegrew, D.K. 2007. 'The busy countryside of Late Roman Corinth. Interpreting ceramic data produced by regional archaeological surveys', Hesperia, 76, 743-784.

Pickersgill, C. and Roberts, P. 2003. 'New light on Roman Sparta. Roman pottery from the Sparta theatre and stoa', BSA, 98, 549-597.

Piérart, M. and Thalmann, J.P. 1980. 'Céramique romaine et médiévale', in Etudes argiennes (BCH supp. vol. 6; Paris), 459-482.

Piéri, D. 2005. Le commerce du vin oriental à l'époque byzantine (Ve - VIIe siècles). Le témoignage des amphores en Gaule (Institut français du Proche-Orient. Bibliothèque archéologique et historique, 174; Beyrouth).

Poblome, J. 1999. Sagalassos Red Slip Ware. Typology and Chronology (Studies in eastern Mediterranean archaeology, 2; Brépols).

Portale, E.C. 2004. ' ed il commercio mediterraneo. Le anfore da trasporto tra l'età di Augusto e la conquista araba', in Livadiotti, M. and Simiakaki, I. (eds), Creta romana e protobizantina. Atti del Congresso internazionale, Iraklion 2000 (Padova), 959-973.

Portale, E.C. and Romeo, I. 2000. 'Le anfore locali di ellenistica e romana', Rei Cretariae Romanae Fautores Acta, 36, 417-426.

Portale, E.C. and Romeo, I. 2001. 'Contenitori da trasporto', in Di Vita, A. (ed), 260410.

Pyrrou, N., Tsaravopoulos, A. and Bojica C.O. 2006 'The Byzantine settlement of 
Antikythera (Greece) in the 5th-7th centuries', in S. A. Luca and V. Sîrbu (eds.) The Society of the Living - the Community of the Dead (from Neolithic to the Christian Era). Proceedings of the 7th International Colloquium on Funerary Archaeology (Sibiu: Bibliotheca Septemcastrensis), 224-236.

URL:

http://arheologie.ulbsibiu.ro/publicatii/bibliotheca/acta\%20V\%20special\%20number/ volum\%20syposion\%20funerary.pdf

Raab, H.A. 2001. Rural Settlement in Hellenistic and Roman Crete. The Akrotiri Peninsula (BAR IS 984; Oxford).

Ramon Torres, J. 2005. Las ánforas fenicio-púnicas del Mediterráneo central y occidental (Universitat de Barcelona, Collecció Instrumenta, 2; Barcelona).

Rendini, P. 1988a. 'Ceramica acroma', in Di Vita, A. (ed.), , $i$ (Monografie della Scuola Archeologica di Atene e delle Missioni Italiane in Oriente, 3; Roma), 229-251.

Rendini, P. 1988b. 'Ceramica da cucina', in Di Vita, A. (ed.), $i$ (Monografie della Scuola Archeologica di Atene e delle Missioni Italiane in Oriente, 3; Roma), 253-261.

Rendini, P. 1997. 'Anfore', in Di Vita and Martin (eds), 371-389.

Rendini, P. 2004. 'Spatheia, tipologia e loro impiego a ', in Livadiotti, M. and Simiakaki, I. (eds), Creta romana e protobizantina. Atti del Congresso internazionale, Iraklion 2000 (Padova), 975-988.

Riemann, O. 1880 Recherches archéologiques sur les Iles ioniennes. iv. Cérigo, (Paris: E. Thorin).

Riley, J. A. 1979. 'The coarse pottery from Berenice', in Lloyd, J.A., Excavations at Sidi Khrebish Benghazi (Berenice). Vol.ii. (Libya Antiqua supp. 5; Tripoli), 91-467.

Rizzo, M.A. 2001. 'Terra sigillata LRC', in Di Vita, A. (ed.), , v, iii. Lo scavo del pretorio, 1989 - 1995. I materiali (Monografie della Scuola Archeologica di Atene e delle missioni italiane in Oriente, 12; Padova), 55-64.

Robinson, H.S. 1959. The Athenian Agora, v. Pottery of the Roman Period. Chronology (Princeton).

Robinson, H.S. 1965. 'The Early Roman pottery', in Weinberg, G.D, Grace, V.R. and Edwards, G.R. (eds), The Antikythera Shipwreck Reconsidered (Transactions of the American Philosophical Society, 55, 3; Philadelphia), 28-29.

Romano, I.B. 1994. 'A Hellenistic deposit from Corinth. Evidence for interim activity (146 - 44 B.C.)', Hesperia, 63, 57-104,

Rotroff, S.I. 2006. The Athenian Agora, xxxiii. Hellenistic pottery. The Plain Wares (Athens).

Sackett, L.H. 1992. Knossos from Greek City to Roman Colony. Excavations at the 
Unexplored Mansion, ii (BSA supp. vol. 21; London).

Saguì, L. 1998. 'Il deposito della Crypta Balbi: una testimonianza imprevedibile sulla Roma de VII secolo?', in Saguì, L. (ed.), Ceramica in Italia VI-VII secolo. Atti del convegno in onore di John W. Hayes (Biblioteca di Archeologia medievale, 14: Roma), 305-330.

Schneider, G. 2000. 'Chemical and mineralogical studies of Late Hellenistic to Byzantine pottery production in the eastern Mediterranean', Rei Cretariae Romanae Fautorum Acta, 36, 525-536.

Sirano, F. 2001. 'Ceramica da fuoco', in Di Vita (ed.), 537-561.

Slane, K.W. 1986. 'Two Deposits from the Early Roman Cellar Building, Corinth', Hesperia, 55, 271-318.

Slane, K.W. 1990. Corinth, xviii, ii. The Sanctuary of Demeter and Kore. The Roman Pottery and Lamps (Princeton).

Slane, K.W. 2000. 'East - West trade in fine wares and commodities. The view from Corinth', Rei Cretariae Romanae Fautorum Acta, 36, 299-312.

Slane, K.W. 2003. ' Corinth's Roman pottery. Quantification and meaning', in Williams, C.K. and Bookidis N. (eds), Corinth, xx. Corinth. The Centenary, $1896-$ 1996 (Princeton), 321-335.

Slane, K. and Sanders, G.D.R. 2005. 'Corinth. Late Roman horizons', Hesperia, 74, 243-297.

Smyth, W.H. 1834 Descriptive Catalogue of a Cabinet of Roman Imperial LargeBrass Medals, Bedford.

Sodini, J.P. 2000. 'Productions et échanges dans le monde protobyzantin, IVe - VIIe siècles. Le cas de la céramique', in Belke, K., Hild, F., Koder, J. and Soustal, P. (eds), Byzanz als Raum. Zu Methoden und Inhalten der historischen Geographie des östlichen Mittelmeerraumes (Österreichische Akademie der Wissenschaften. Philosophisch-Historische Klasse. Denkschriften, 283; Wien), 181-208.

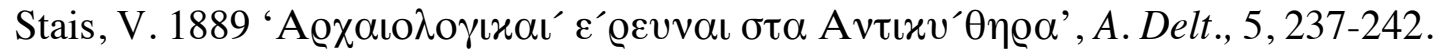

Tchernia, A. 1986. Le vin de l'Italie romaine. Essai d'histoire économique d'après les amphores (Bibliothèque des Ecoles françaises d'Athènes et de Rome, 261; Rome)

Threatte, L. 1980. The Grammar of Attic Inscriptions (Berlin).

Tréglia, J.C. 2005. 'Importations de céramiques communes de mer Egée et de Constantinople en Gaule méridionale durant l'antiquité tardive (IVe - VIIe s.)', in Ma, J., Esparraguera, G., Buxeda i Garrigos, J. and Cau Ontiveros, M.A. (eds), $L R C W, 1$. Late Roman Coarse Wares, Cooking Wares and Amphorae in the Mediterranean. Archaeology and Archaeometry (BAR IS 1340; Oxford), 299-310. 


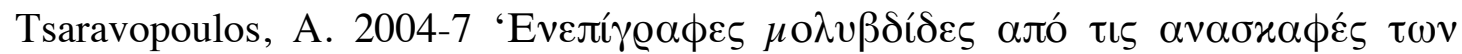

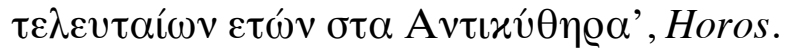

Van der Werff, J.H. 1977-1978. 'Amphores de tradition punique à Uzita', BABesch, 52-53, 171-200.

Villa, L. 1994. 'Le anfore tra tardoantico e medioevo', in Lusuardi Siena, L. (ed.), Ad mensam. Manufatti d'uso da contesti archeologici fra tarda antichità e medioevo (Udine), 335-437.

Vogeikoff-Brogan N. and Apostolakou, S. 2004. 'New evidence of wine production in East Crete in the Hellenistic period', in Eiring, J. and Lund, J. (eds), Transport Amphorae and Trade in the Eastern Mediterranean. Acts of the International Colloquium at the Danish Institute at Athens, 2002 (Århus 2004), 417-427.

Vogt, C. 2004. 'Echanges et économie proto-byzantines d'Eleutherna d'après les témoins ceramiques', in Livadiotti, M. and Simiakaki, I. (eds), Creta romana e protobizantina. Atti del Congresso internazionale, Iraklion 2000 (Padova), 923-944.

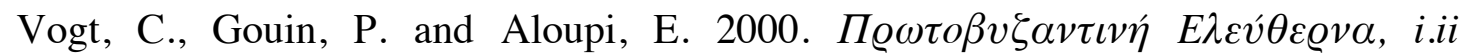
(Rethymmo).

Vroom, J., Bevan, A. and J. Conolly in preparation 'Medieval to Recent Pottery and Land Use on Antikythera, Greece'.

Whitbread, I.K. 1995. Greek Transport Amphorae: a Petrological and Archaeological Study (London).

Will, E.L. 1983. 'Exportation of olive oil from Baetica to the eastern Mediterranean', in Blasquez, J.M. and Remesal, J. (eds), Producción y comercio del aceite en la antigüedad. II congreso internacional, Sevilla 1982 (Madrid), 392-440.

Will, E.L. 1997. 'Shipping amphoras as indicators of economic Romanization in Athens', in Hoff, M.C. and Rotroff, S.I. (eds), The Romanization of Athens. Proceedings of an International Conference held at Lincoln, Nebraska, April 1996 (Oxbow Monographs, 94; Oxford), 117-133.

Williams, C.F. and Zervos, O.E. 1983. 'Corinth, 1982: East of the Theater', Hesperia, $52,1-47$

Williams, D.F. 2005. 'Late Roman Amphora 1: a study of diversification', in Briese, M.B. and Vaag, L.E. (eds), Trade relations in the Eastern Mediterranean from the Late Hellenistic Period to Late Antiquity: The Ceramic Evidence. Acts from a PhD Seminar for Young Scholars, Sandbjerg 1998 (Odense), 157-168.

Wintermeyer, U. and Bumke, H. 2004. Didyma, iii. Ergebnisse der Ausgrabungen und Untersuchungen seit dem Jahre 1962, 2. Die Hellenistische und Frühkaiserzeitliche Gebrauchskeramik. Auf Grundlage der stratifizierten Fundkeramik aus dem Bereich der Heiligen Strasse (Mainz). 
Wolff, S.R. 2004. 'Punic amphoras in the eastern Mediterranean', in Eiring, J. and Lund, J. (eds), Transport Amphorae and Trade in the Eastern Mediterranean. Acts of the International Colloquium at the Danish Institute at Athens, 2002 (Århus 2004), 451-457.

Yangaki, A.G. 2004-2005. 'Amphores crétoises. Le cas d'Eleutherna, en Crète', $B C H$, 128-129, 503-523.

Yangaki, A.G. 2005. La céramique des IVe - VIIIe siècles ap. J.-C. d'Eleutherna. Sa place en Crète et dans le bassin égéen (Athènes).

Zemer, A. 1978. Storage Jars in Ancient Sea Trade (Haifa) 


\section{FIGURE CAPTIONS}

Figure 1. Maps of Antikythera showing a) the island's general location in the Aegean and the distribution of Roman (mainly Late Roman) sherds recovered from systematic survey, and b) the locations of denser artefact scatters along with the UTM grid (zone $34 \mathrm{~N}$, WGS84) used in the catalogue.

Figure 2. Line drawings of sherds $\mathbf{1}$ to $\mathbf{1 0}$

Figure 3. Line drawings of sherds $\mathbf{1 1}$ to $\mathbf{1 8}$

Figure 4. Line drawings of sherds $\mathbf{1 9}$ to $\mathbf{2 8}$

Figure 5. Line drawings of sherds 29 to 39

Figure 6. Line drawings of sherds $\mathbf{4 0}$ to $\mathbf{4 8}$

Figure 7. Line drawings of sherds 49 to 60

Figure 8. Line drawings of sherds 61 to 69

Figure 9. Line drawings of sherds $\mathbf{7 0}$ to $\mathbf{7 8}$

Figure 10. Line drawings of sherds $\mathbf{7 9}$ to $\mathbf{8 6}$

Figure 11. Line drawings of sherds 87 to 93

Figure 12. Line drawings of sherds 94 to 101 


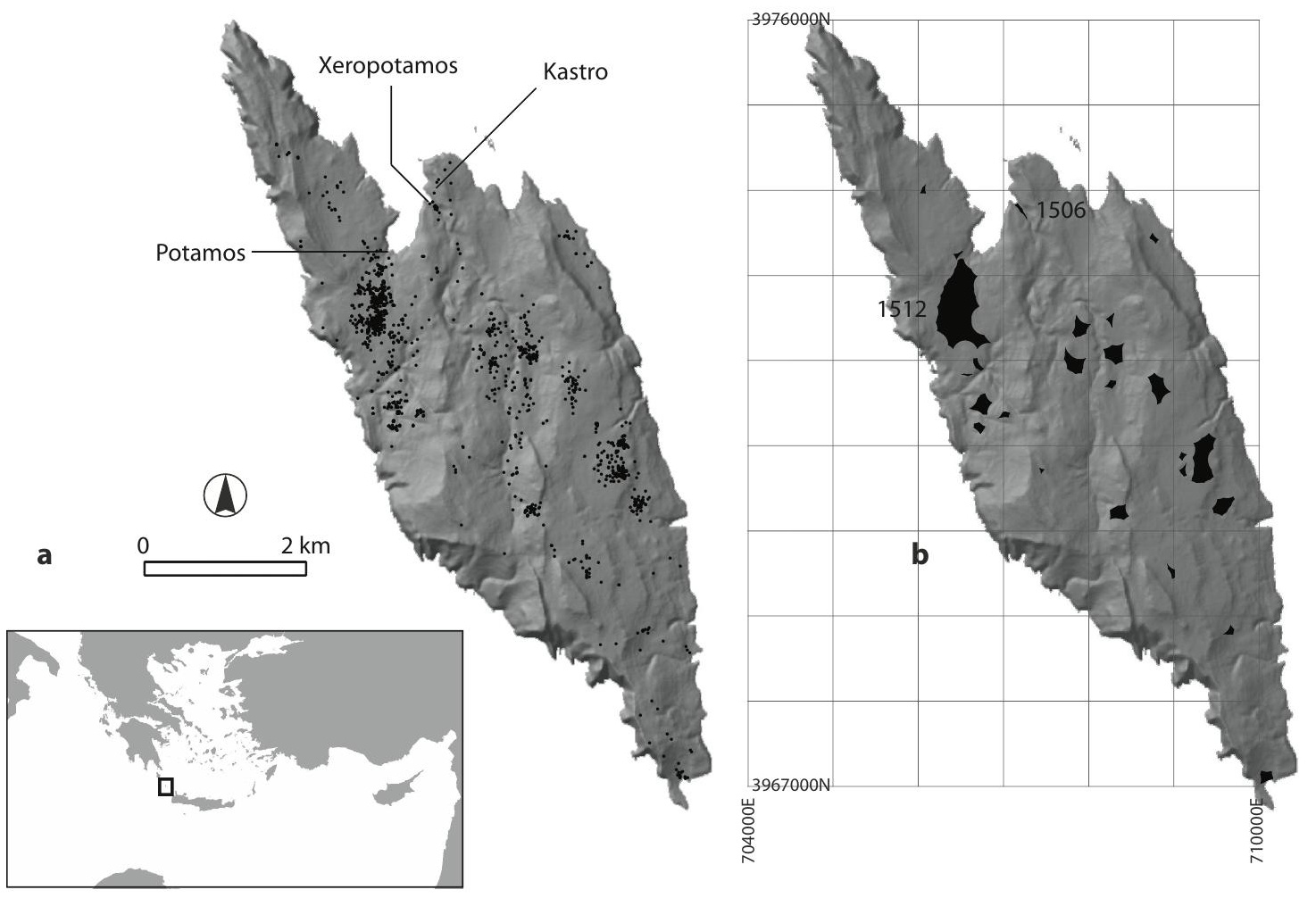


1

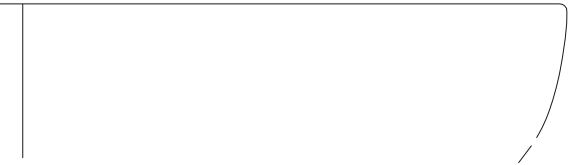

0

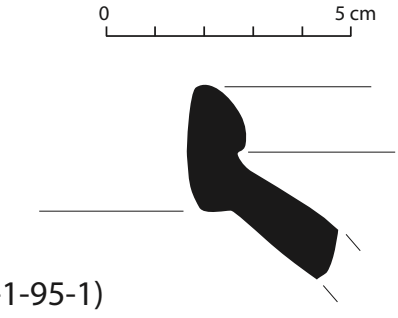

3 (3177-6-1-95-1)

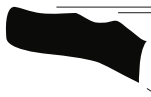

1 (8130-28-1-65-8)

2 (4268-18-1-5-1)
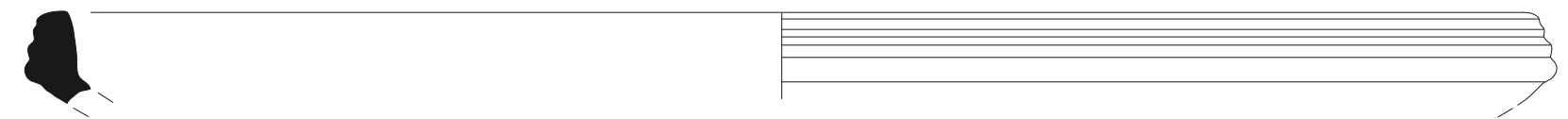

4 (3394-12-1-15-1)

5 (3678-34-1-5-4)
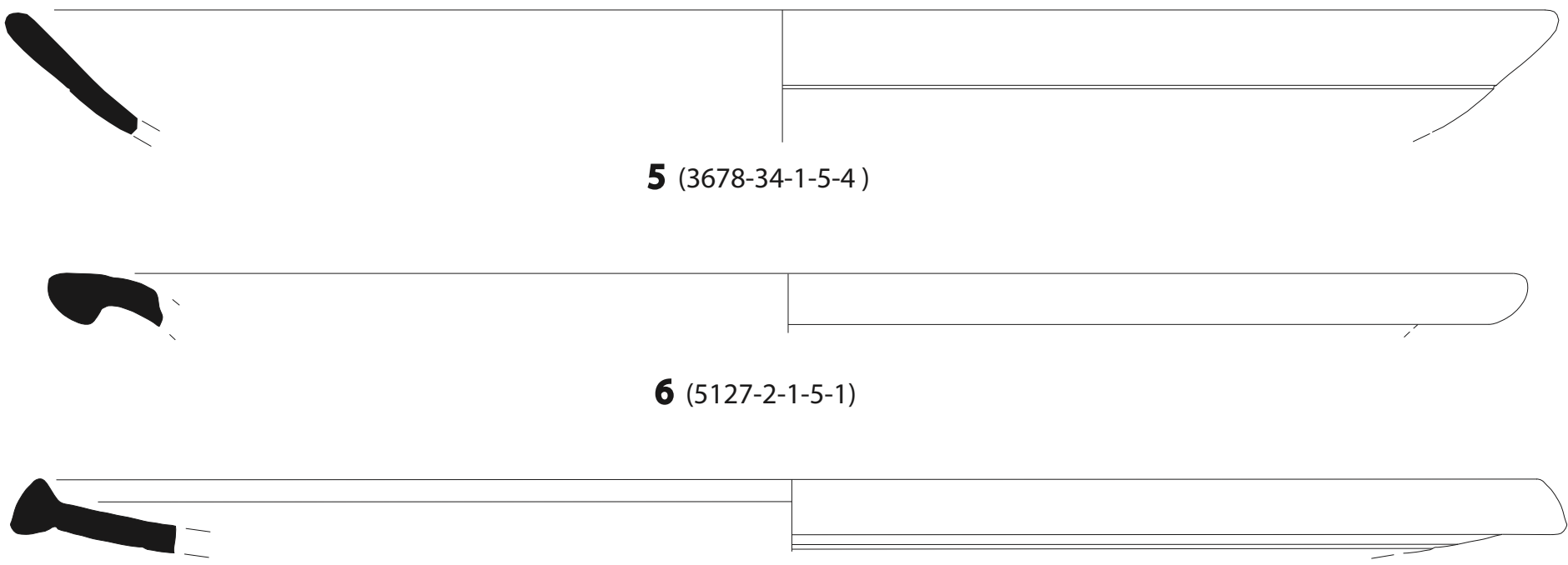

7 (12294-58-1-15-1)
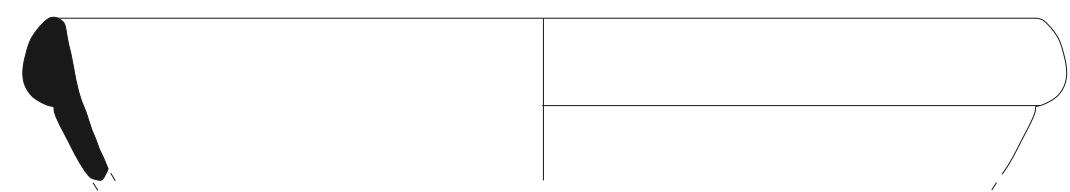

8 (7135-25-1-45-1)
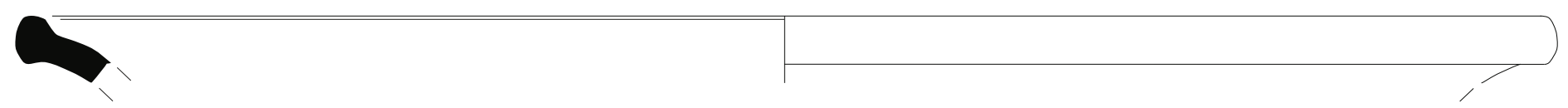

\section{9 (4074-5-1-5-1)}
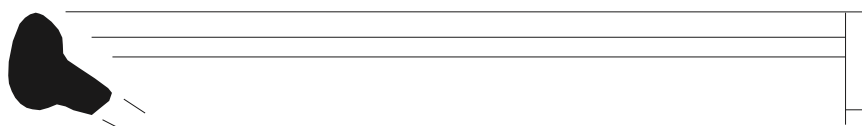

10 (3680-42-1-5-1) 

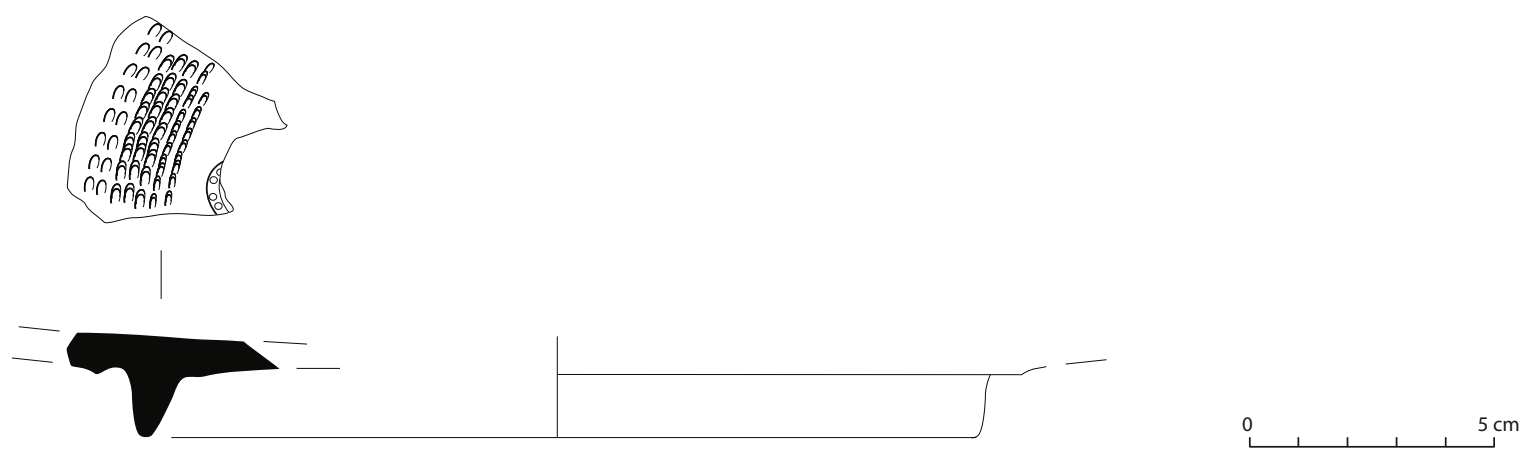

11 (8115-36-1-55-1)

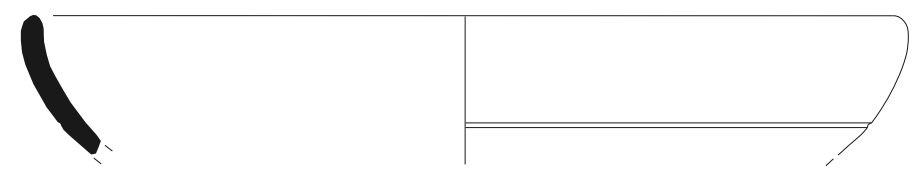

12 (3680-42-1-15-2)
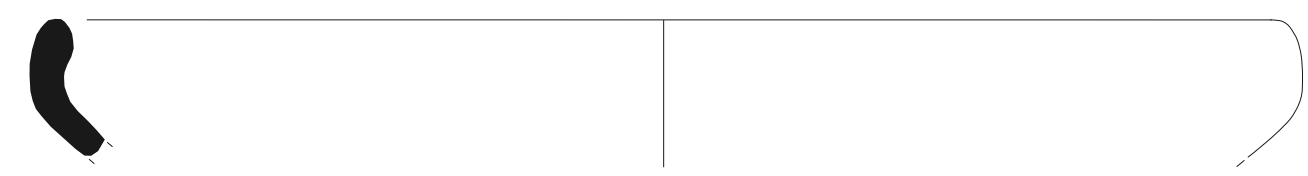

13 (7129-40-1-25-1)
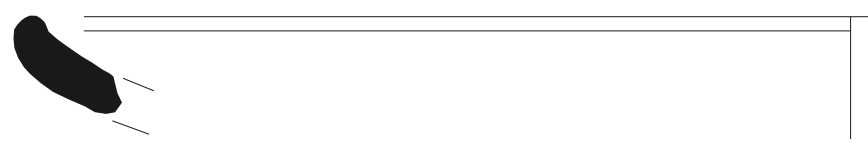

14 (4222-29-1-35-1)
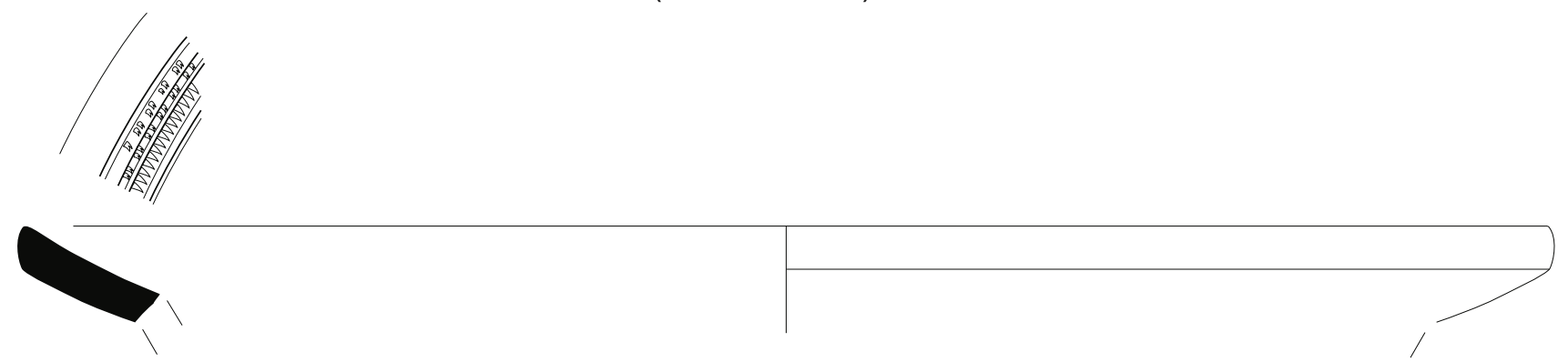

15 (17005-103-1-35-1)
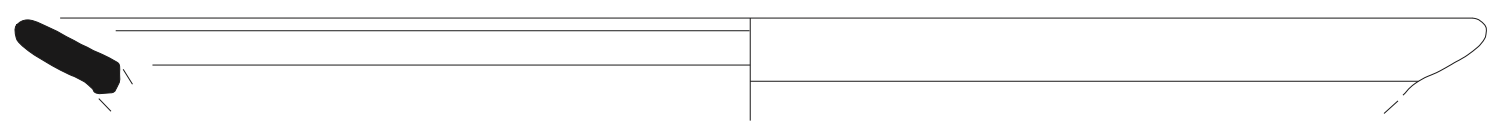

16 (4076-14-1-15-3)

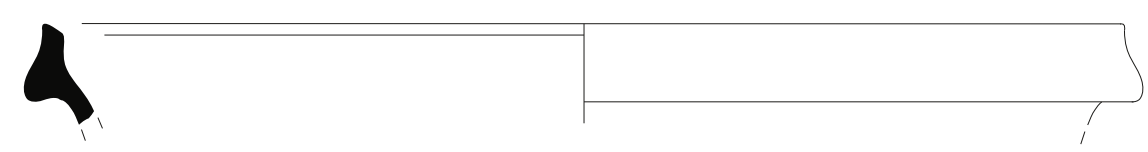

17 (8019-36-1-55-2)
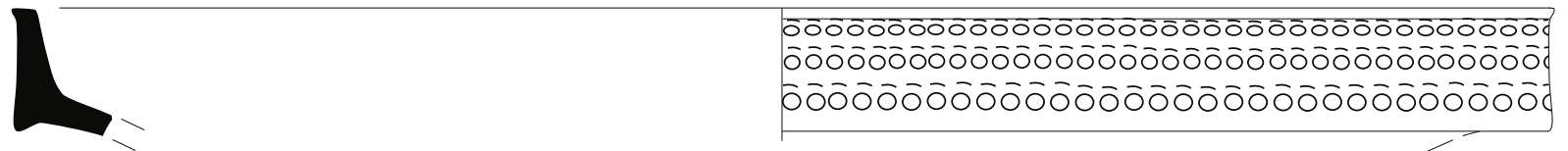

18 (8231-26-1-5-1) 
19 (6003-2-1-5-1)
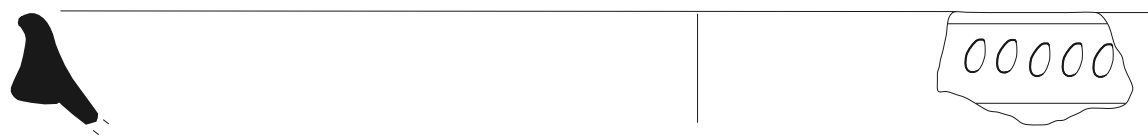

20 (3393-16-1-85-1)

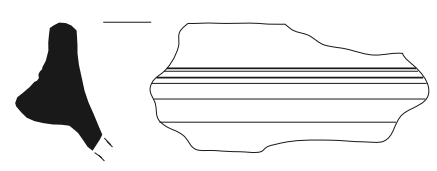

21 (8113-20-1-45-1)

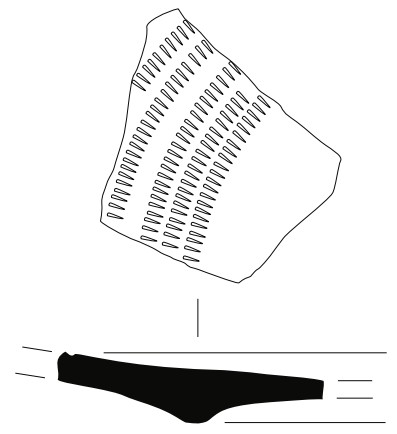

23 (6007-16-1-65-1)

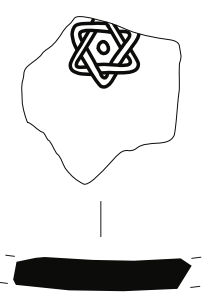

27 (12042-57-1-25-6)
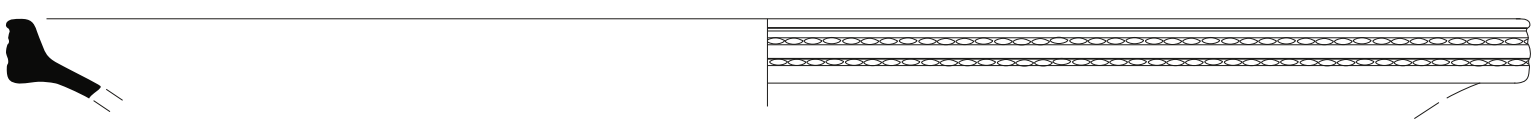

22 (7138-5-1-55-2)
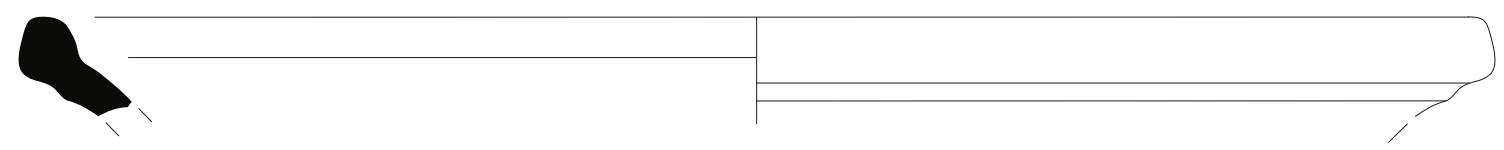

24 (4020-17-1-15-5)

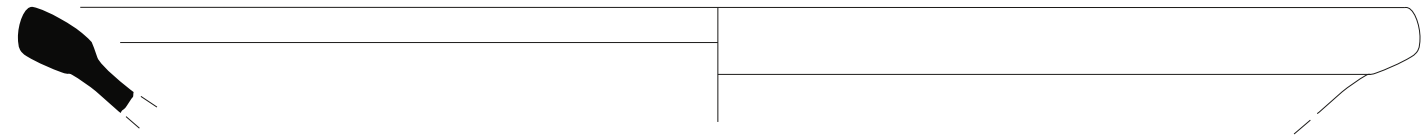

25 (10012-44-1-85-1)

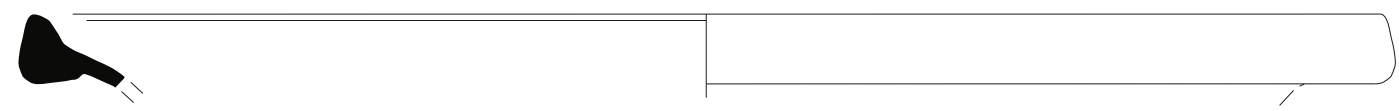

26 (4042-18-1-65-1)
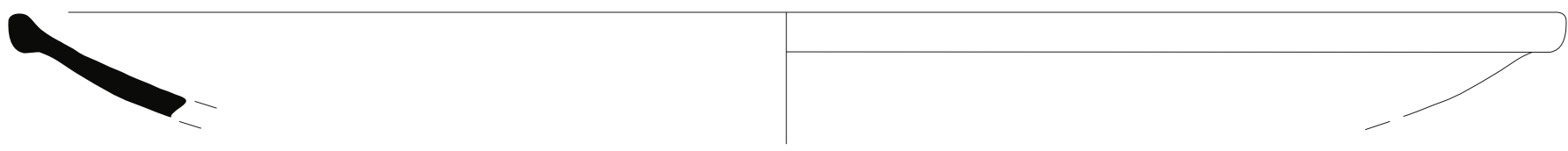

28 (4035-10-1-35-1) 


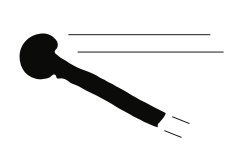

29 (3623-42-1-5-1)

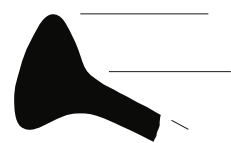

30 (4298-20-1-35-8) $5 \mathrm{~cm}$
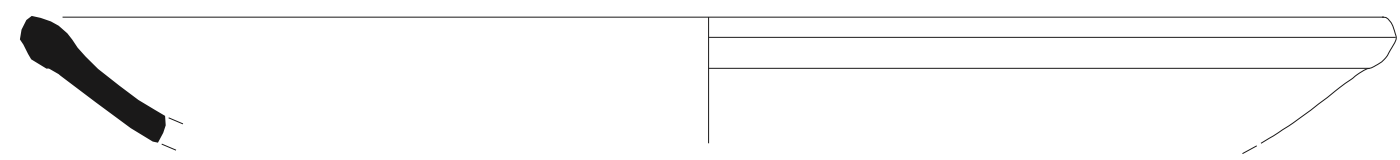

31 (4034-10-1-65-1)
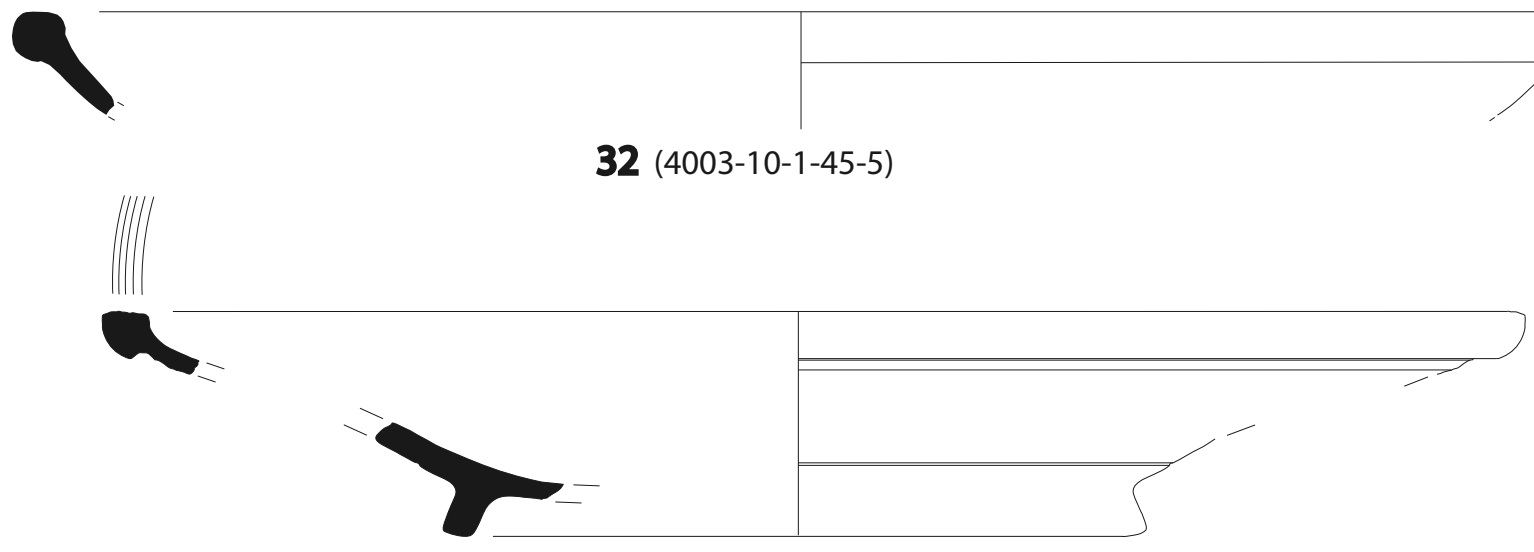

33 (4050-17-1-25-9)
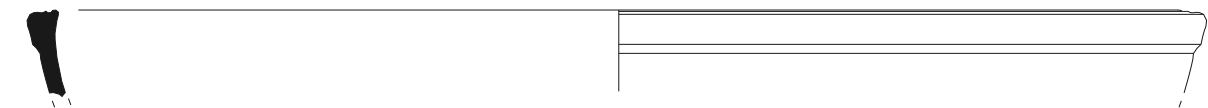

34 (3459-19-1-17-5)
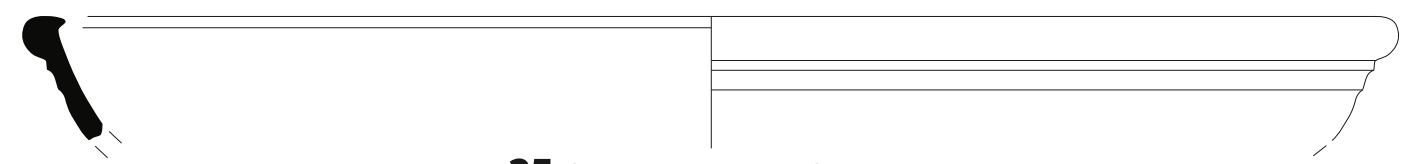

35 (12171-57-1-65-1)
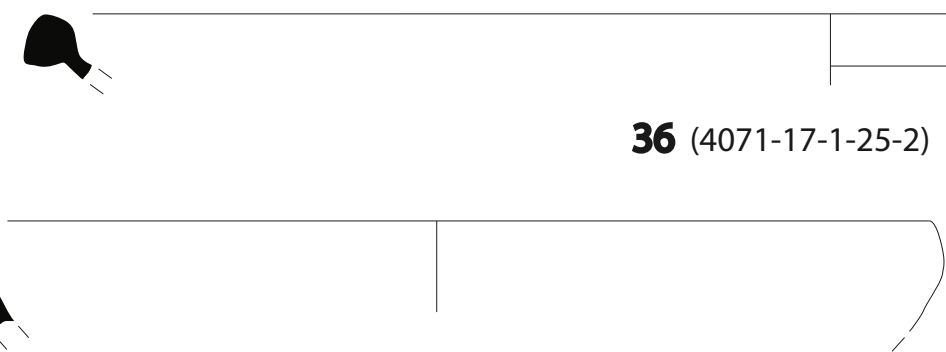

37 (4256-39-1-60-1)

36 (4071-17-1-25-2)
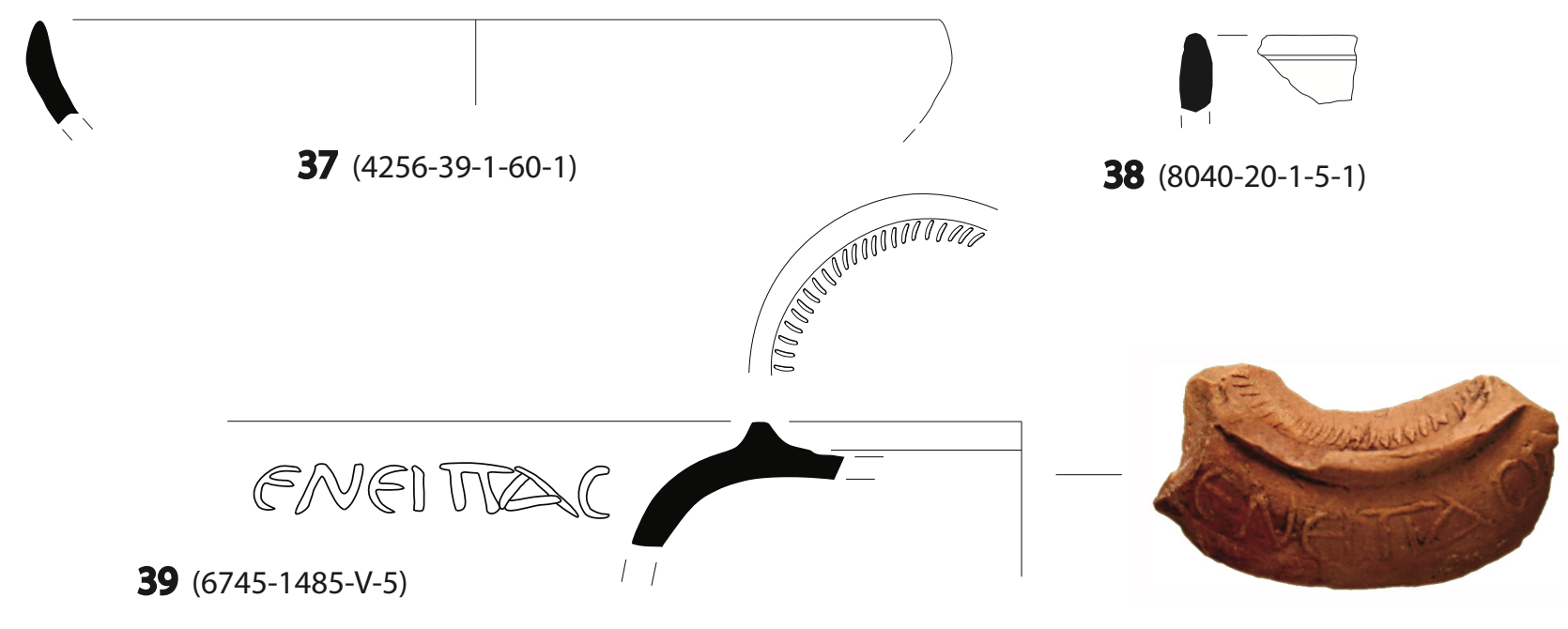


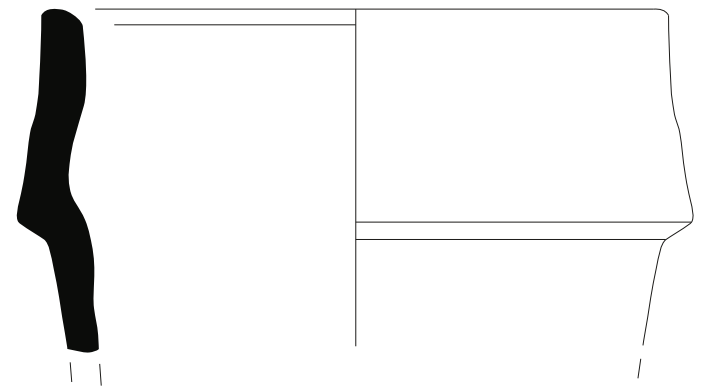

40 (4303-20-1-15-13)

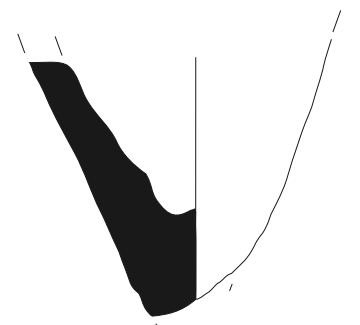

42 (3392-12-1-55-2)

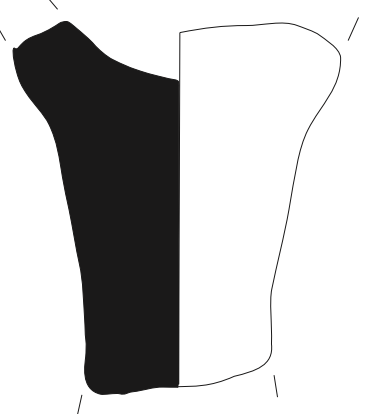

43 (1062-6-1-35-1)

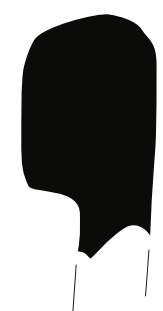

41 (0075-7135-S-37)
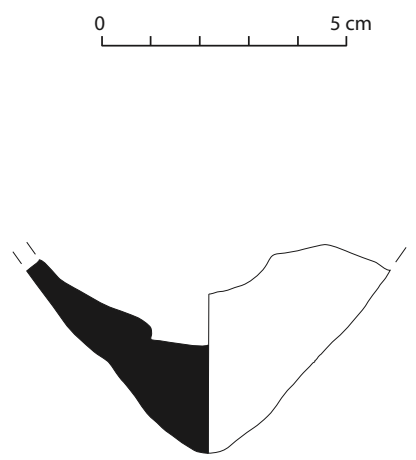

44 (1128-3-1-85-2)
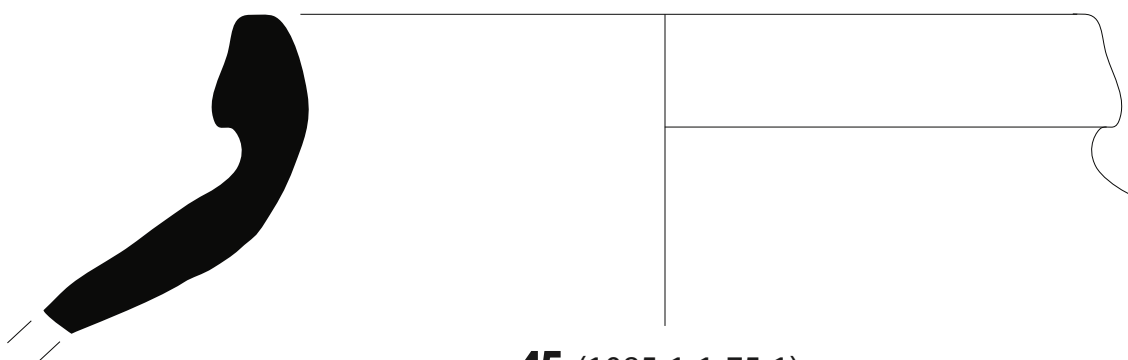

45 (1085-1-1-75-1)
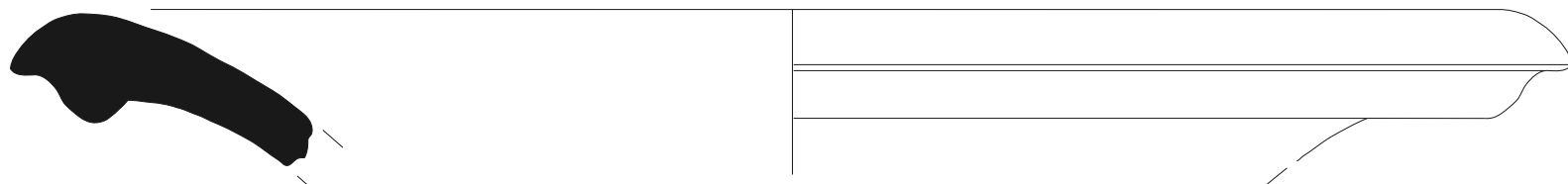

46 (3006-3-1-5-1)
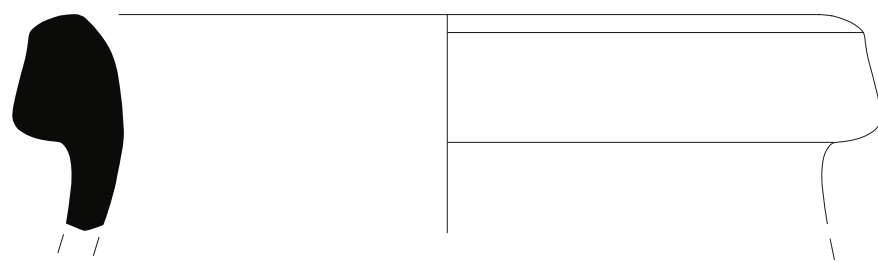

47 (4300-28-1-25-4)

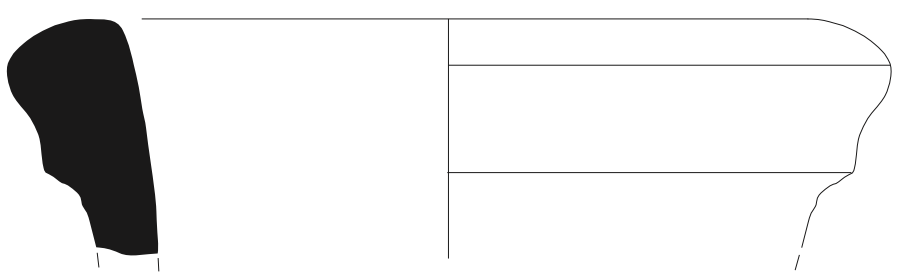

48 (8181-28-1-35-1) 

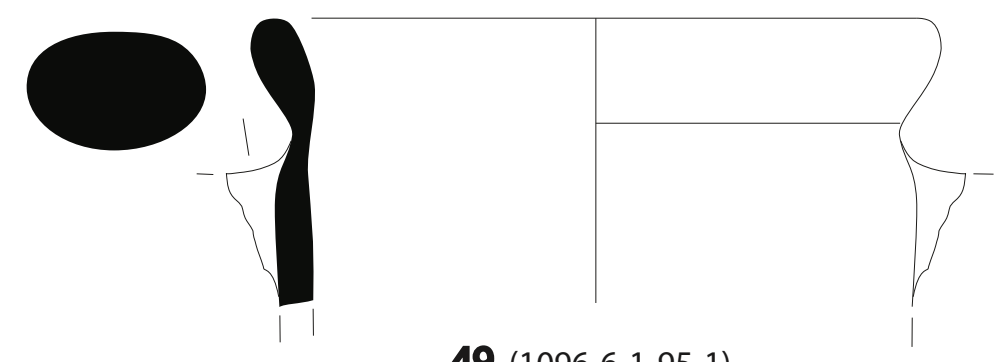

49 (1096-6-1-95-1)
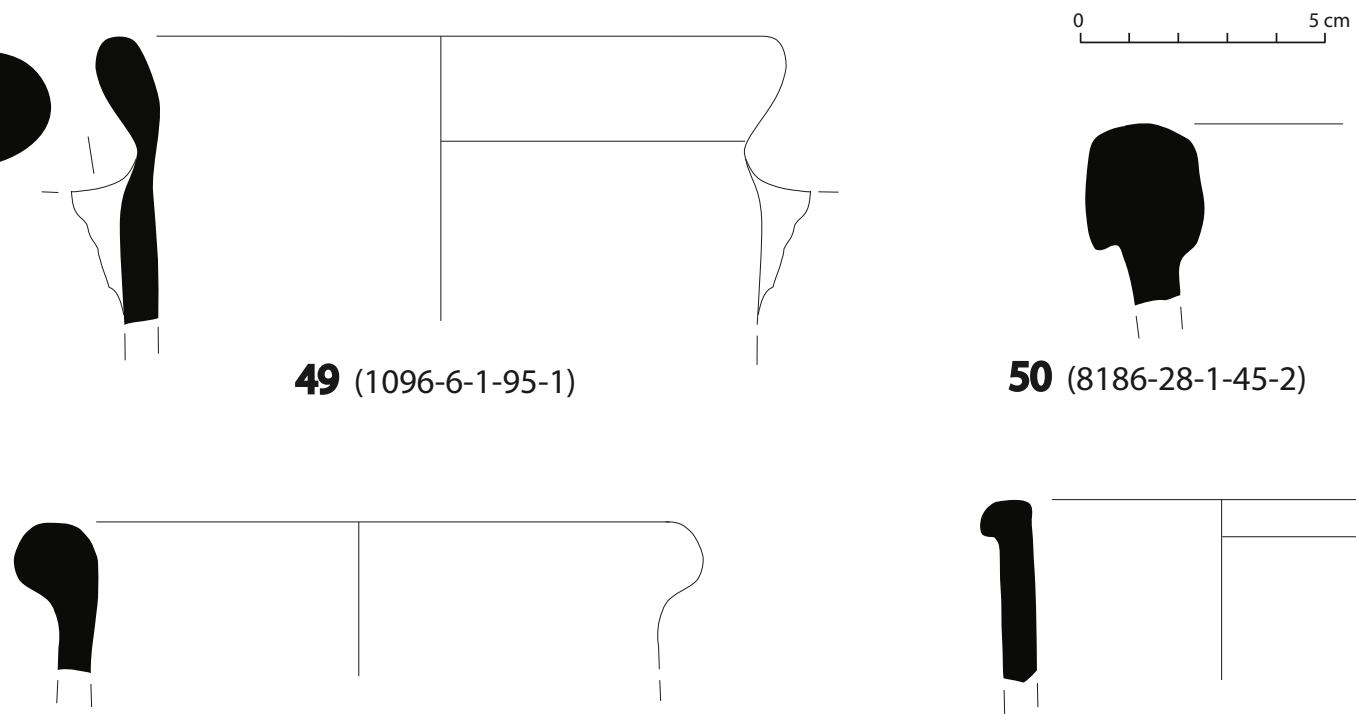

51 (1072-1-1-75-1)

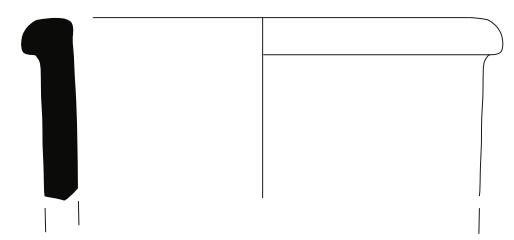

52 (4299-29-1-25-1)

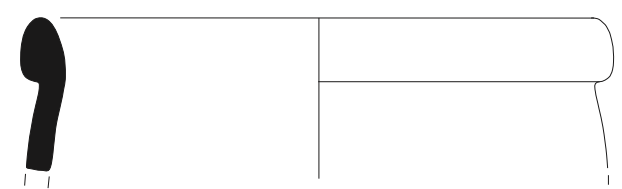

53 (4314-20-1-35-1)
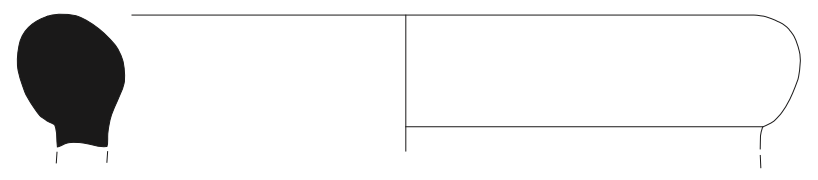

55 (3002-19-1-25-1)

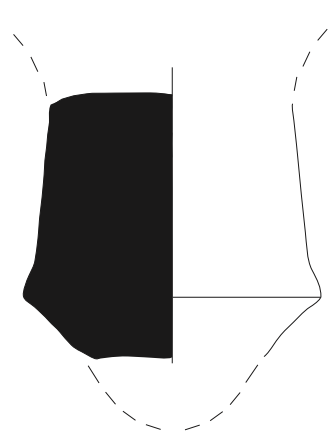

57 (1107-5-1-65-1)

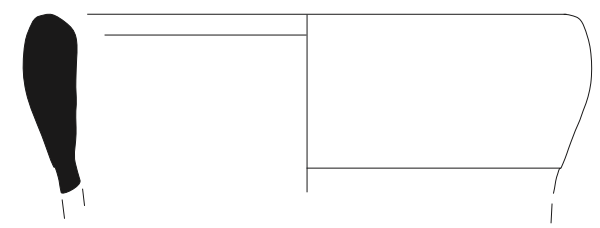

59 (8173-27-1-25-1)

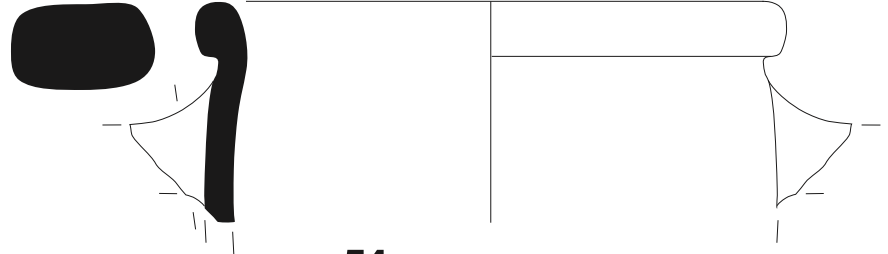

54 (4314-28-1-35-1)

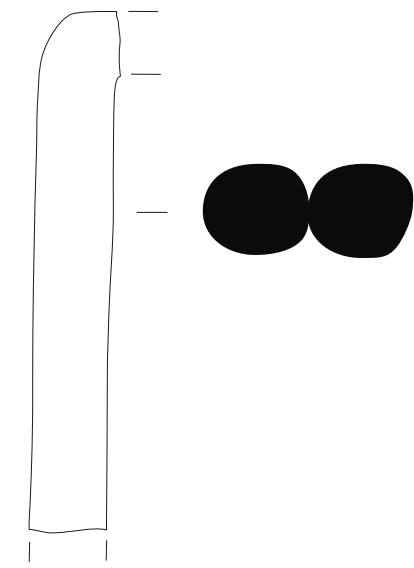

56 (1068-6-1-75-3)

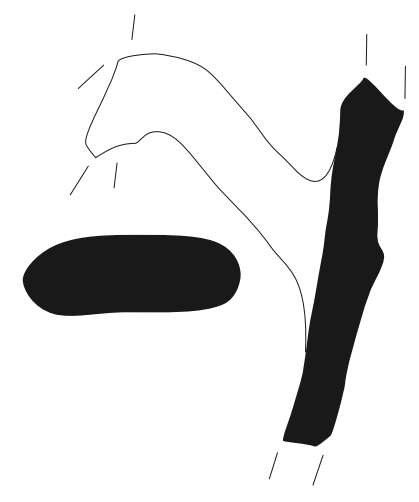

58 (4018-5-1-55-1)

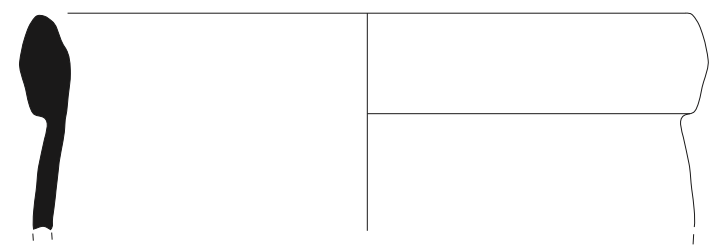

60 (4304-28-1-45-3) 


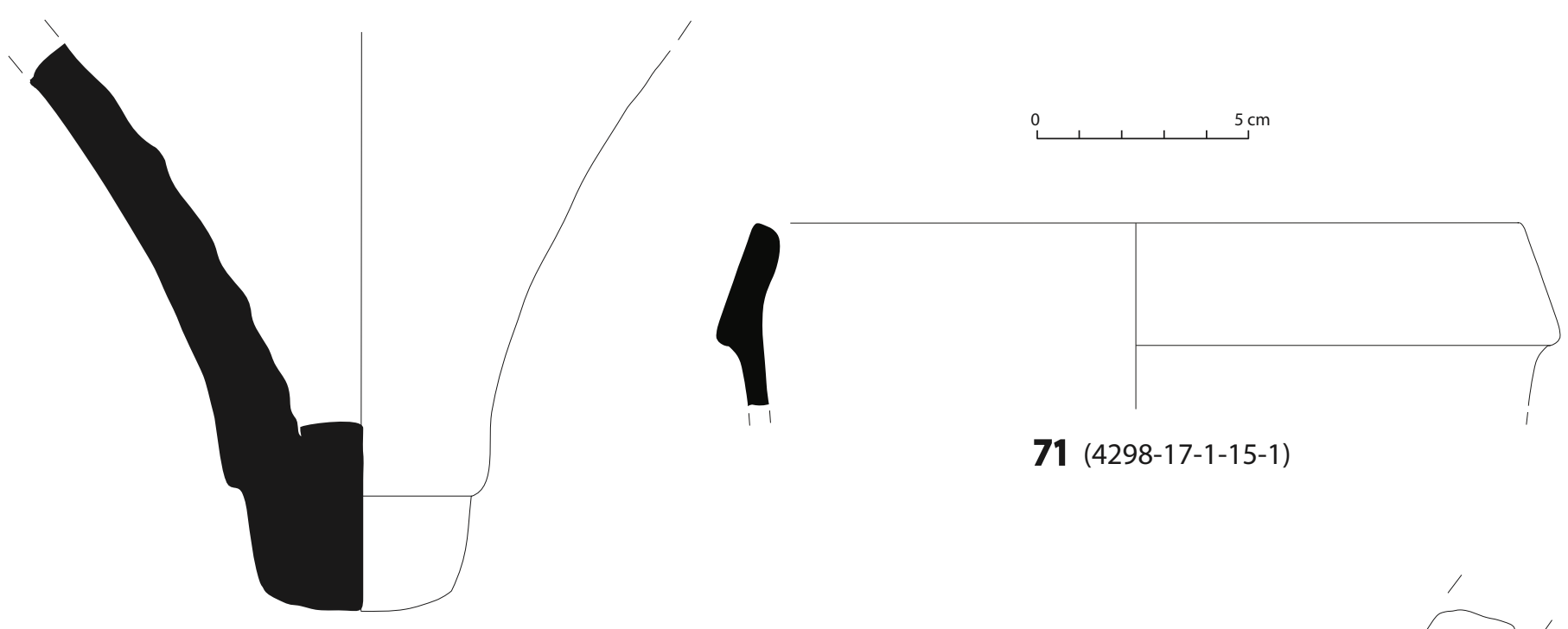

71 (4298-17-1-15-1)

70 (12083-58-1-5-1)
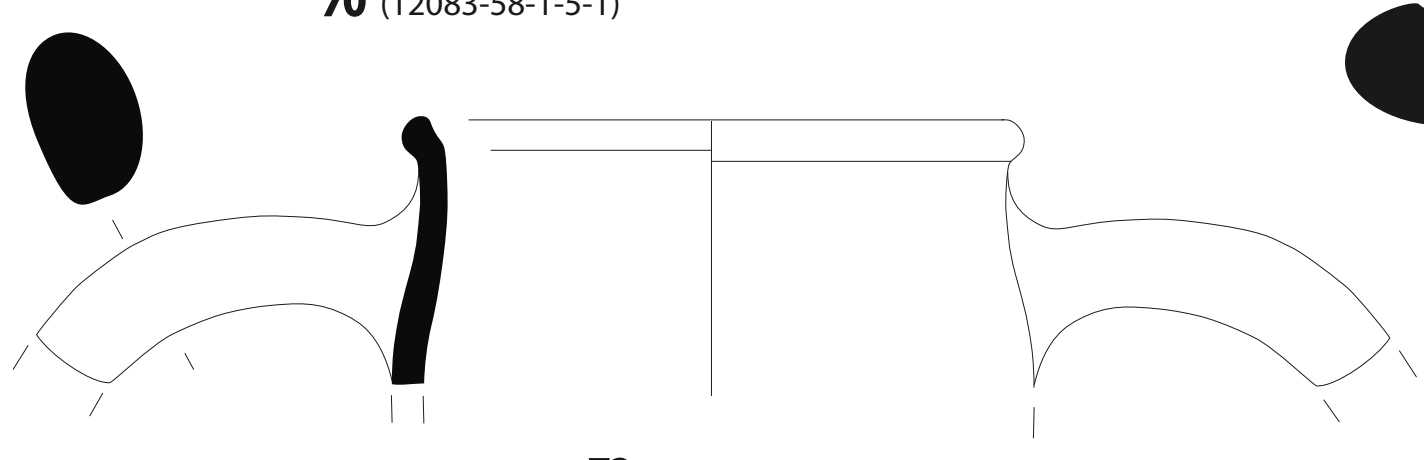

72 (3678-19-1-5-1)

73 (3437-28-1-95-2)

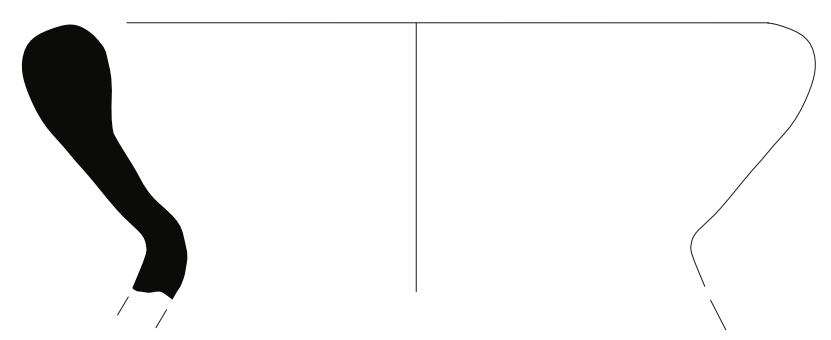

74 (8188-26-1-45-1)

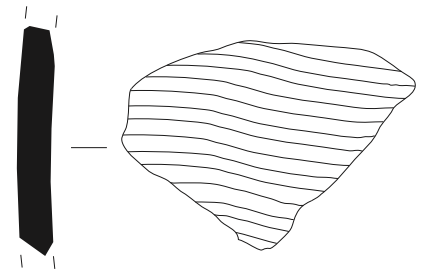

75 (3437-28-1-95-2)

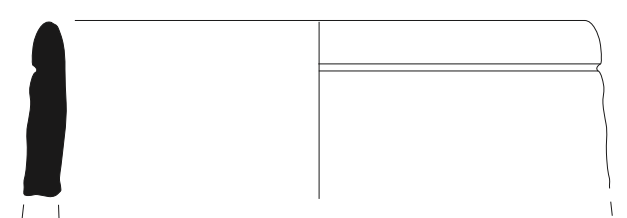

76 (4055-17-1-85-6)

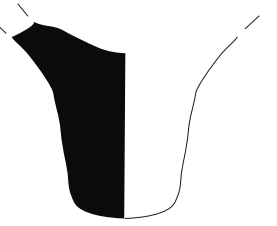

78 (6067-23-1-55-1)

77 (4082-5-1-95-2) 


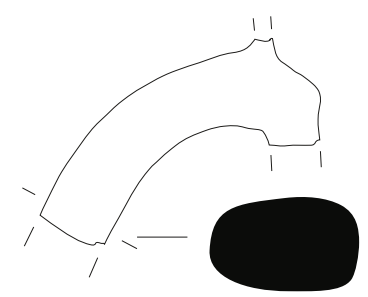

79 (11308-59-1-5-1)
80 (1131-3-1-45-1)

81 (1087-3-1-15-2)
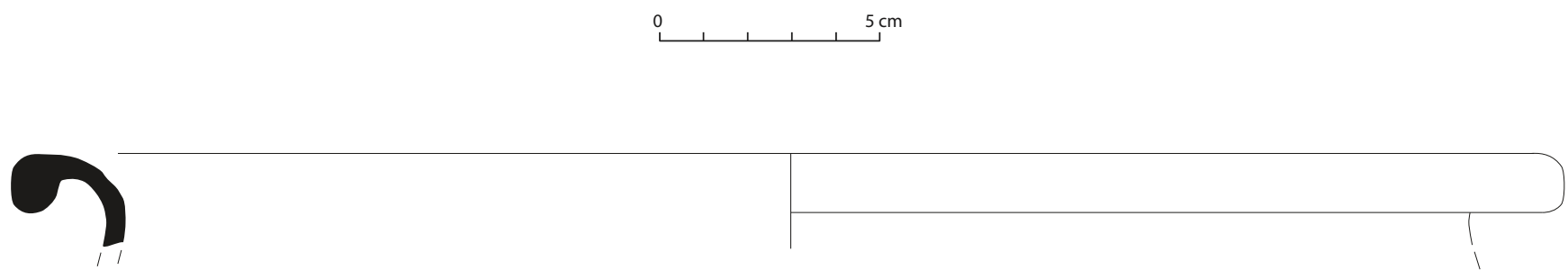

82 (4072-5-1-65-2)
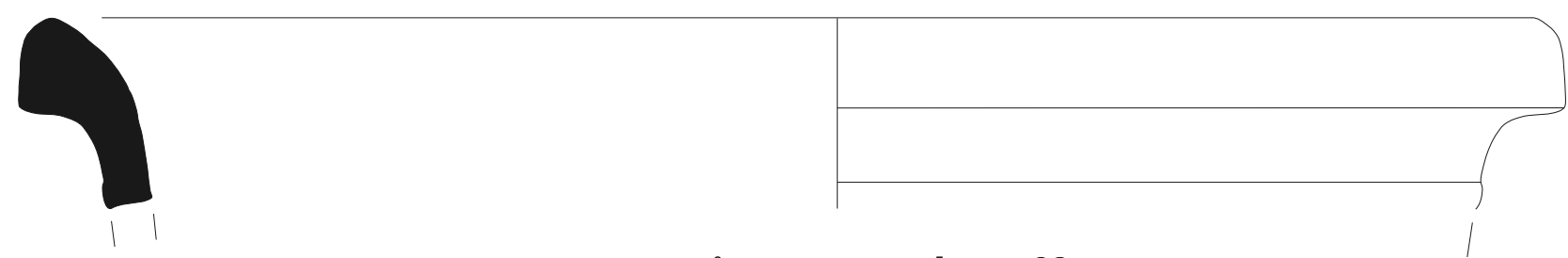

83 (3436-5-1-15-1)
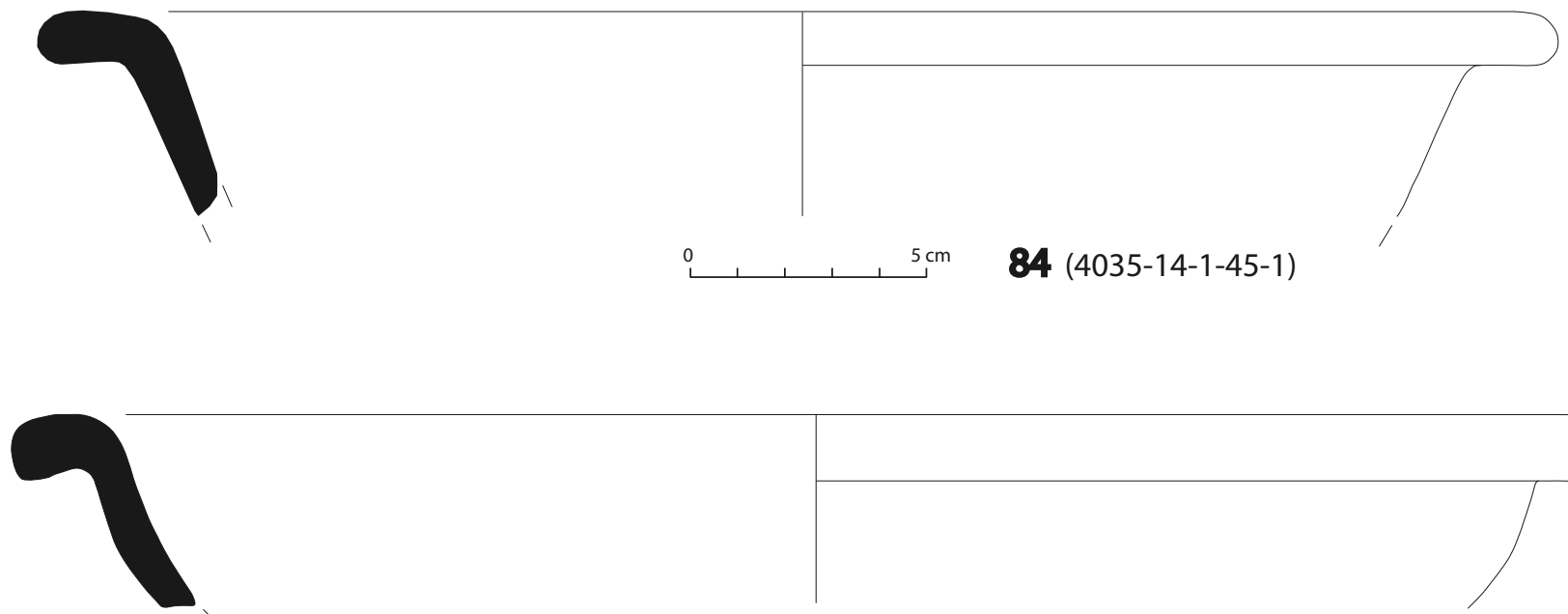

85 (8186-28-1-45-1) 

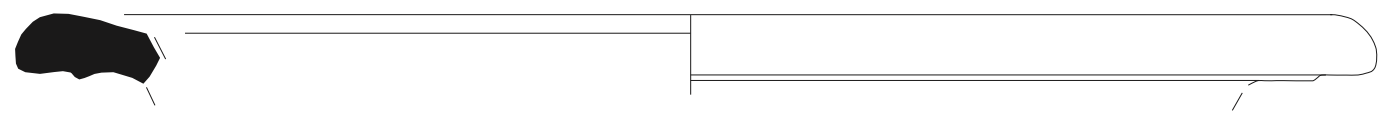

87 (11326-57-1-25-3)

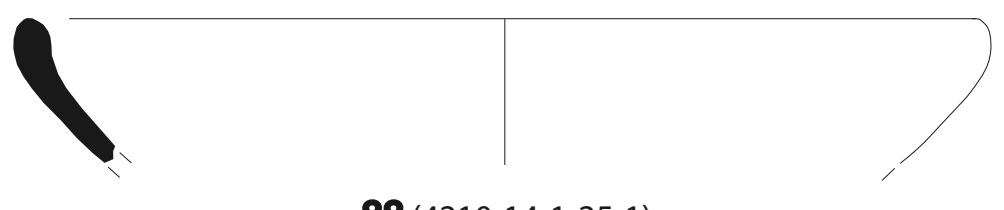

88 (4210-14-1-25-1)

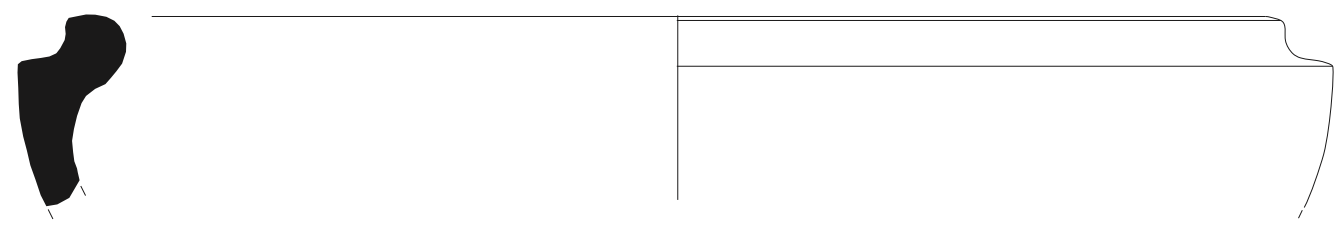

89 (4034-14-1-35-2)

4

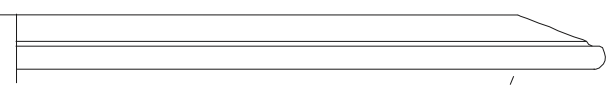

90 (4210-29-1-25-1)

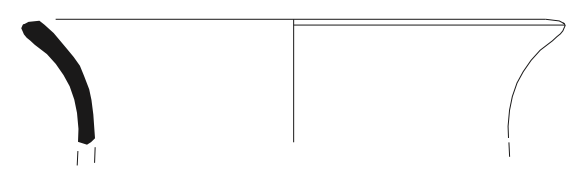

91 (12062-57-1-15-1)

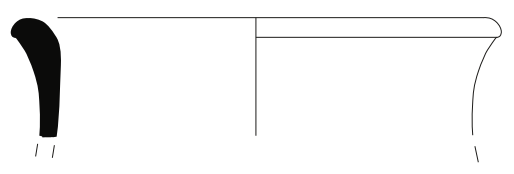

93 (3447-14-1-25-1)

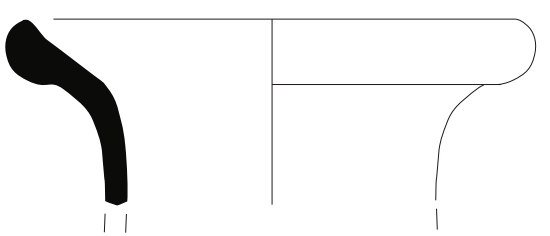

92 (4047-18-1-15-1)

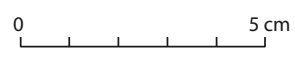




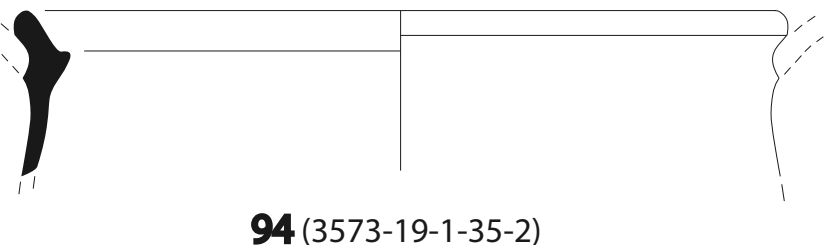

94 (3573-19-1-35-2)

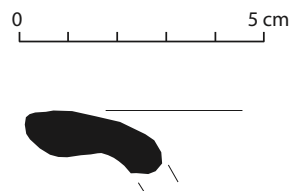

95 (3179-6-1-95-2)

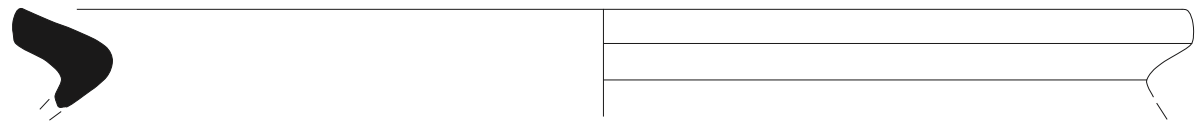

96 (12083-58-1-25-1)
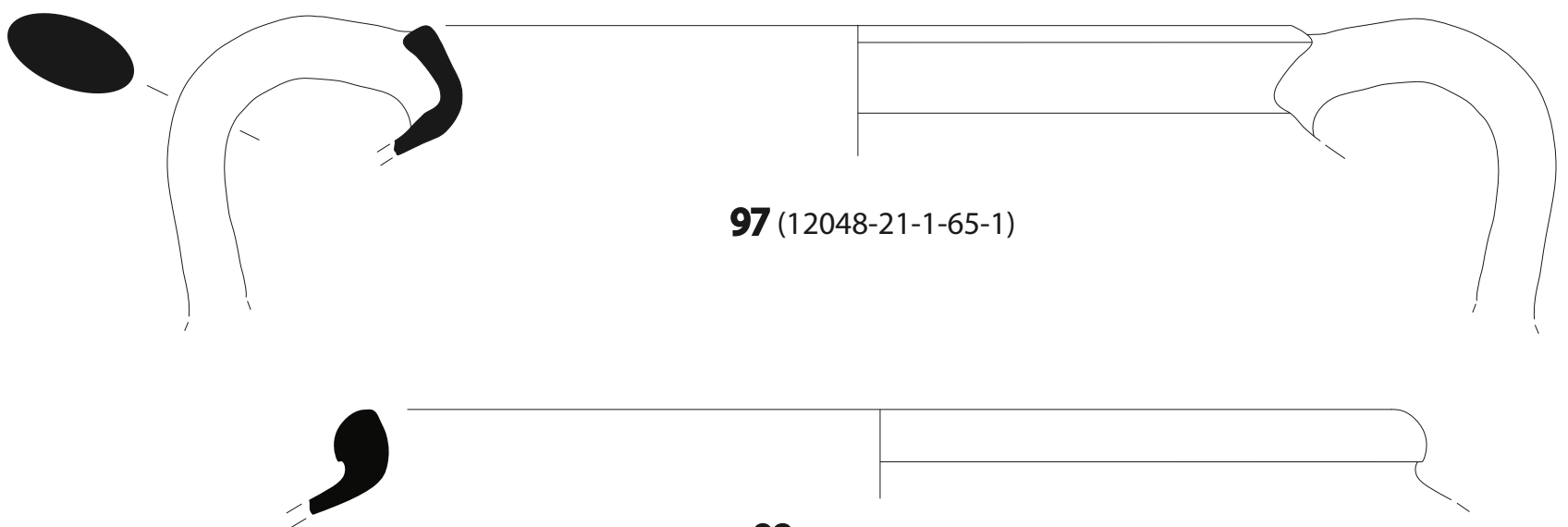

97 (12048-21-1-65-1)

98 (3481-19-1-15-1)

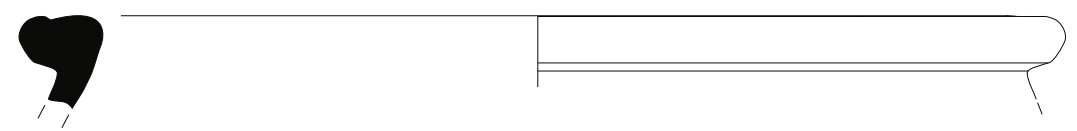

99 (4004-5-1-45-9)
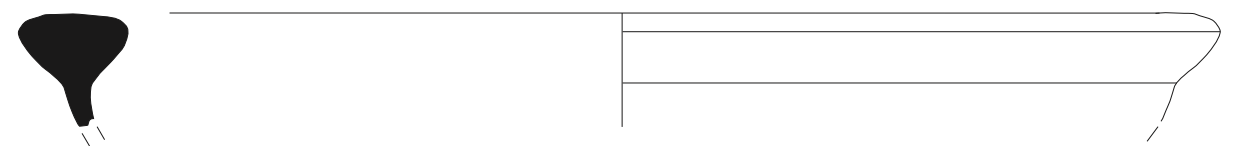

100 (4005-18-1-65-1)
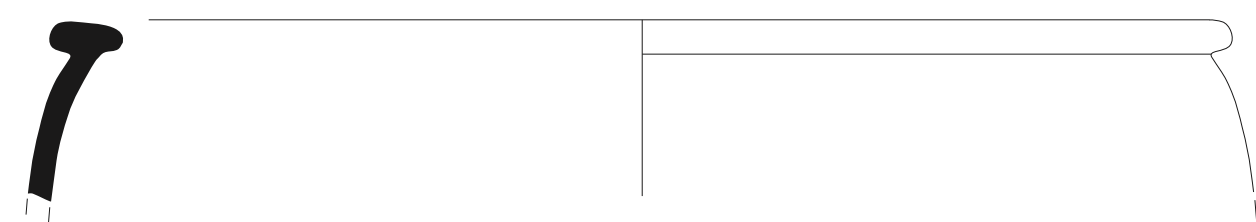

101 (12300-58-1-55-1) 